\title{
PRODUCTION, PURIFICATION, CHARACTERIZATION AND CLONING \\ OF THE CYCLOMALTODEXTRINASE FROM BACILLUS SUBTILIS HIGH TEMPERATURE GROWTH TRANSFORMANT H-17: COMPARISON TO THE PARENT ENZYMES FROM BACILLUS SUBTILIS 25S AND BACILLUS CALDOLYTICUS C2
}

BY

BRADLEY MARTIN KROHN

A DISSERTATION PRESENTED TO THE GRADUATE SCHOOL OF THE UNIVERSITY OF FLORIDA IN PARTIAL FULFILLMENT OF THE REQUIREMENTS FOR THE DEGREE OF DOCTOR OF PHILOSOPHY

UNIVERSITY OF FLORIDA 
This dissertation is dedicated to my parents, Lou and Doc, for their support, enthusiasm, patience, and understanding during the course of my doctoral program at the University of Florida. 


\section{ACKNOWLEDGEMENTS}

I would like to thank Dr. James Lindsay, my major advisor, for his guidance, support, motivation, patience, commitment, and never-ending enthusiasm for my doctoral research and graduate program. I am extremely grateful to the other members of my doctoral committee, Dr. Dennis Duggan, Dr. Lonnie Ingram, Dr. Ronald Schmidt, Dr. Maurice Marshall, and Dr. Jesse Gregory, for their interest, suggestions, review of manuscripts, and use of their equipment. I am deeply appreciative to the Food Science and Human Nutrition Department for providing me with a graduate assistantship for the duration of my research.

I wish to thank the students and postdocs in the lab of Dr. L.O. Ingram for their assistance and interaction while I worked in their lab for three months. Thanks go to Thom, Dirk, Morgan, Bee, Melissa and Larry, for making our lab an enjoyable, fun, and efficient environment to work in. I am also grateful to Walter Jones for his availability and professional photography, and to Edward Jaggers for washing my glassware. Finally, my sincerest thanks go to my family, Carole, Frank, Jeff, Frank, my grandparents, and aunts and uncles for all their love, advice, and support. 


\section{TABLE OF CONTENTS}

page

ACKNOWLEDGEMENTS. . . . . . . . . . iii

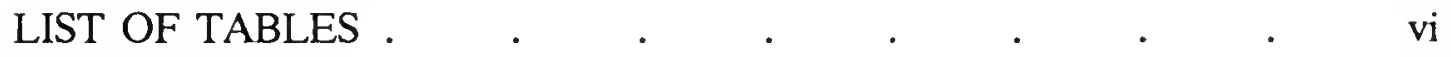

LIST OF FIGURES $\quad . \quad$. $\quad . \quad$. $\quad . \quad$. $\quad$. viii

ABSTRACT . $\quad . \quad$. $\quad . \quad$. $\quad . \quad$. $\quad$. $\quad$ xii

CHAPTERS

1 INTRODUCTION . $\quad . \quad$. $\quad . \quad . \quad$. 1

2 REVIEW OF LITERATURE $\quad$. $\quad . \quad$. $\quad$. 7

Thermophiles and Thermophily $\quad$. $\quad$. $\quad 7$

The Origin and Genetics of Thermophiles . 10

Thermostability of Cell Components . $\quad$. 14

Protein Engineering of Industrially

Important Enzymes. $\quad$. $\quad$. $\quad$. $\quad$. $\quad 29$

Microbial Amylases in Starch Bioprocessing . 36

Bacterial Cyclomaltodextrinases . . . $\quad 39$

3 PURIFICATION, CHARACTERIZATION, AND COMPARISON OF THE CYCLO-

MALTODEXTRINASE FROM B. SUBTILIS

25S, B. CALDOLYTICUS C2, AND

B. SUBTILIS HIGH TEMPERATURE

GROWTH TRANSFORMANT H-17 . . . 45

Materials and Methods . $\quad . \quad$. $\quad . \quad 46$

Results and Discussion $\quad . \quad 6 \quad . \quad . \quad . \quad 53$ 
4 SUBSTRATE SPECIFITIES, AFFINITIES, AND CLEAVAGE PATTERNS OF THE CYCLOMALTODEXTRINASE FROM $B$. SUBTILIS 25S, B. CALDOLYTICUS C2, AND THE B. SUBTILIS HIGH TEMPERATURE GROWTH TRANSFORMANT H-17 . . . 74

Materials and Methods . $\quad . \quad$. $\quad . \quad 74$

Results and Discussion . . . . . . $\quad 77$

5 CLONING OF THE CYCLO-

MALTODEXTRINASE GENE FROM

B. SUBTILIS HIGH TEMPERATURE GROWTH TRANSFORMANT H-17 . $\quad$. $\quad$. 89

Materials and Methods $\quad . \quad 2 \quad . \quad 2 \quad 90$

Results and Discussion . $\quad . \quad . \quad . \quad 110$

6 SUMMARY AND CONCLUSIONS . . . $\quad 142$

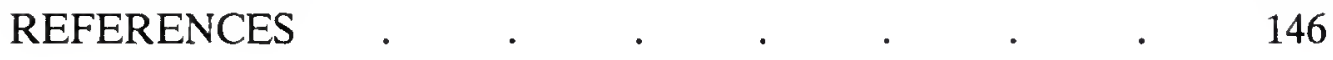

BIOGRAPHICAL SKETCH $\quad$. $\quad$. . . . $\quad 160$ 


\section{LIST OF TABLES}

Table

page

1 Purification of $B$. subtilis $25 \mathrm{~S}$ cyclomaltodextrinase $\quad$. $\quad$. 54

2 Purification of B. caldolyticus C2 cyclomaltodextrinase . . 55

3 Purification of $B$. subtilis H-17 cyclomaltodextrinase . $\quad$. 56

4 Biochemical and biophysical comparison of

B. subtilis $25 \mathrm{~S}, B$. caldolyticus $\mathrm{C} 2$, and

B. subtilis H-17 cyclomaltodextrinase $\quad$. $\quad$. $\quad$. $\quad$. 60

5 Cationic inhibition of $B$. subtilis $25 \mathrm{~S}$,

$B$. caldolyticus $\mathrm{C} 2$, and $B$. subtilis

H-17 cyclomaltodextrinase . . . . . . 64

6 Amino acid compositions of $B$. subtilis $25 \mathrm{~S}$,

$B$. caldolyticus $\mathrm{C} 2$, and $B$. subtilis

$\mathrm{H}-17$ cyclomaltodextrinase . $\quad$. $\quad$. $\quad$. 71

7 Experimental relative rates of hydrolysis of malto-oligosaccharides, cyclodextrins, and polysaccharides by $B$. subtilis $25 \mathrm{~S}, B$. caldolyticus $\mathrm{C} 2$, and $B$. subtilis $\mathrm{H}-17$ cyclomaltodextrinase 
$8 \quad \mathrm{~K}_{\mathrm{m}}$ and $\mathrm{V}_{\max }$ values of $B$. subtilis $25 \mathrm{~S}$ and

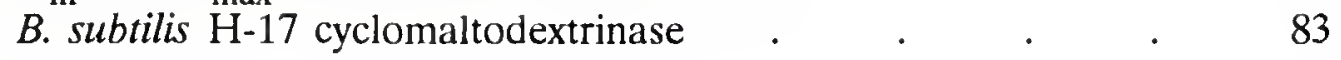

9 Comparison of cyclomatodextrinase activity between B. subtilis YB886 carrying pPL708 with no insert, and $B$. subtilis YB886 carrying pPL708 with a probe-positive $3 \mathrm{~kb}$ Eco RI fragment 


\section{LIST OF FIGURES}

Figure

page

1 SDS-PAGE of purified B. subtilis $25 \mathrm{~S}$

cyclomaltodextrinase on a $7.5 \%$ polyacrylamide gel

2 SDS-PAGE of purified B. caldolyticus $\mathrm{C} 2$

cyclomaltodextrinase on a $7.5 \%$ polyacrylamide gel . $\quad .58$

3 SDS-PAGE of purified B. subtilis $\mathrm{H}-17$

cyclomaltodextrinase on a $7.5 \%$ polyacrylamide gel $\quad . \quad 5 \quad 59$

4 Isoelectric focusing gel of purified $B$. subtilis

25S, B. caldolyticus $\mathrm{C} 2$, or B. subtilis

H-17 cyclomaltodextrinase . $\quad$. $\quad$. $\quad$. $\quad . \quad$. 61

5 Effect of $\mathrm{pH}$ on the activity of (A) B. subtilis

$25 S$ cyclomaltodextrinase, (B) B. caldolyticus

C2 cyclomaltodextrinase, and (C) B. subtilis

H-17 cyclomaltodextrinase .

63

6 Effect of temperature on the activity of
(A) B. subtilis $25 \mathrm{~S}$ cyclomaltodextrinase,
(B) B. caldolyticus $\mathrm{C} 2$ cyclomaltodextrinase, and
(C) B. subtilis $\mathrm{H}-17$ cyclomaltodextrinase .
66 
Figure

page

7 (A) Effect of temperature and incubation time on the thermostability of $B$. subtilis $25 \mathrm{~S}$ cyclomaltodextrinase.

(B) Effect of temperature, incubation time, and $0.02 \%$

2-Me or $0.01 \mathrm{mM}$ EDTA on the thermostability of

$B$. caldolyticus $\mathrm{C} 2$ cyclomaltodextrinase. (C) Effect

of temperature, incubation time, and $0.02 \% 2-\mathrm{Me}$ on

the thermostability of the B. subtilis $\mathrm{H}-17$

cyclomaltodextrinase. (D) Effect of temperature,

incubation time, and $0.005 \mathrm{mM}$ EDTA on the

thermostability of $B$. subtilis $\mathrm{H}-17$ cyclomaltodextrinase

68

8 TLC of $10 \mathrm{~min}(\mathrm{~A}), 1 \mathrm{~h}(\mathrm{~B})$, and $3 \mathrm{~h}(\mathrm{C})$ products of linear malto-oligosaccharide hydrolysis by

$B$. subtilis $25 \mathrm{~S}, B$. caldolyticus $\mathrm{C} 2$, or

B. subtilis $\mathrm{H}-17$ cyclomaltodextrinase

9 TLC of 20 min hydrolysis products of

CDs and $1.5 \mathrm{~h}$ hydrolysis products of polysaccharides by $B$. subtilis $25 \mathrm{~S}$

or $B$. subtilis $\mathrm{H}-17$ cyclomaltodextrinase

85

10 TLC of products of pullulan hydrolysis

by $B$. subtilis $25 S$ and $B$. subtilis

$\mathrm{H}-17$ cyclomaltodextrinase

11 Genetic map of E. coli plasmid cloning vector

pUC18 (top) and $B$. subtilis plasmid cloning

vector pPL708 (bottom)

12 General strategy for cloning Sau 3A fragments

into the Bam HI site of plasmid vector pUC18.

13 Starch-LA agar plate stained with iodine crystal vapors 
Figure

14 Pullulan-Reactive Red-LA agar plate which had been previously exposed to chloroform vapors .

$15 \mathrm{~N}$-terminal amino acid sequence of the $B$. subtilis $\mathrm{H}-17$ thermostable cyclomaltodextrinase .

16 Southern blot hybridization of DNA probe to complete restriction enzyme digests of $B$. subtilis $\mathrm{H}-17$ DNA

17 Southern blot hybridization of DNA probe to amplified gene libraries constructed in pUC18

18 Hybridization of DNA probe to colony lift of $E$. coli

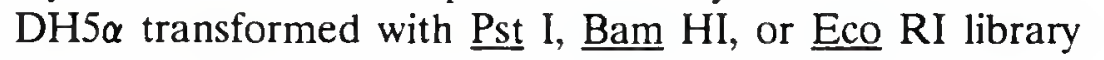

19 Immunologically-screened colony lifts of $E$. coli DH5 $\alpha$ transformed with gene libraries constructed in pUC18. Top membranes: $E$. coli transformed with amplified Pst I library. Bottom membranes: E. coli transformed with amplified Bam HI library . . . . . .

20 Agarose gel electrophoresis of digested plasmid DNA from several immuno-positive $E$. coli DH5 $\alpha$ transformants identified on the corresponding colony lift

21 Southern blot analysis of Pst I digested plasmid DNA from several immuno-positive $E$. coli $\mathrm{DH} 5 \alpha$ transformants carrying pUC18 with a Pst I insert (top). Southern blot analysis of Bam $\mathrm{HI}$ digested plasmid DNA from several immuno-positive $E$. coli DH5 $\alpha$ transformants carrying pUC18 with a Bam $\mathrm{HI}$ insert (bottom) 
Figure

22 Colony lift of subcultured immuno-positive

E. coli DH5 $\alpha$ transformants. Colonies carrying pUC18 with a Pst I or Bam HI insert show

23 General strategy for cloning DNA probepositive Eco RI fragments into the Eco RI site of plasmid vector pPL708.

24 Immunologically-screened colony lifts of B. subtilis YB886 transformed with Eco RI library constructed in pPL708

25 Southern blot hybridization of DNA probe to Eco RI digested plasmid DNA from four B. subtilis YB886 immuno-positive transformants

26 Southern blot hybridization of DNA probe to Eco RI digest of cesium chloride density gradient-purified pPL708 carrying the probe-positive Eco RI insert

27 Immunologically-screened colony lifts of E. coli XL1-Blue transformed with pUC18 carrying the DNA probe-positive Eco RI fragment purified from pPL708

28 Ochterlony gel diffusion of purified rabbit polyclonal antisera against late log phase cell-free extracts 
Abstract of Dissertation Presented to the Graduate School of the University of Florida in Partial Fulfillment of the Requirements for the Degree of Doctor of Philosophy

\title{
PRODUCTION, PURIFICATION, CHARACTERIZATION AND CLONING OF THE CYCLOMALTODEXTRINASE FROM BACILLUS SUBTILIS HIGH TEMPERATURE GROWTH TRANSFORMANT H-17: COMPARISON TO THE PARENT ENZYMES FROM BACILLUS SUBTILIS 25S AND BACILLUS CALDOLYTICUS C2
}

\author{
BY \\ BRADLEY MARTIN KROHN
}

December 1991

Chairman: James A. Lindsay Major Department: Food Science and Human Nutrition

The p-nitrophenyl- $\alpha$-D-maltoside hydrolyzing cyclomaltodextrinase (EC 3.2.1.54) from the mesophile Bacillus subtilis 25S, the obligate thermophile Bacillus caldolyticus $\mathrm{C} 2$, and the Bacillus subtilis high-temperature growth transformant H-17 were purified, characterized and compared. All three cyclomaltodextrinases displayed maximal rates of hydrolysis and identical hydrolysis patterns for linear malto-oligosaccharides and $\alpha$ - and $\beta$-cyclodextrin, with maltose and glucose as the final products. Starch, amylose, and amylopectin were degraded slowly to maltose, 
in an exo-fashion by preferential cleavage of maltose units from the nonreducing ends. Neither enzyme showed activity against p-nitrophenyl- $\alpha$-D-glucopyranoside, maltose, isomaltose, isomaltotriose or panose. The enzymes demonstrated pullulan hydrolase activity due to their hydrolysis of pullulan to glucose, maltose, and (iso)panose.

The 25S, C2, and H-17 enzymes were composed of two identical subunits of $M_{r} 55,000,60,000$, and 55,000, respectively. The 25S, C2, and H-17 enzymes had a $\mathrm{pI}$ of $4.85, \mathrm{pH}$ optimum of $7.5,7.0$, and 7.5 , and $\mathrm{K}_{\mathrm{m}}$ values for the chromogenic substrate p-nitrophenyl- $\alpha$-D-maltoside of $2.96 \mathrm{mM}, 1.31 \mathrm{mM}$, and $1.46 \mathrm{mM}$, respectively. The $25 \mathrm{~S}$ enzyme exhibited optimal activity between $35-37^{\circ} \mathrm{C}$, and complete inactivation after $10 \mathrm{~min}$ at $45^{\circ} \mathrm{C}$. This contrasts with the $\mathrm{C} 2$ enzyme which showed optimal activity at $60^{\circ} \mathrm{C}$, and retained $100 \%$ of initial activity at $60^{\circ} \mathrm{C}$ for $2 \mathrm{~h}$, and with the $\mathrm{H}-17$ enzyme which showed optimal activity between $65^{\circ} \mathrm{C}$ and $68^{\circ} \mathrm{C}$, and retained $100 \%$ of initial activity at $65^{\circ} \mathrm{C}$ for $1 \mathrm{~h}$. Both the $\mathrm{C} 2$ and $\mathrm{H}-17$ enzymes required 2-mercaptoethanol or EDTA for thermostability. A comparison of the amino acid compositions showed an increase in proline, alanine, and leucine residues for the $\mathrm{C} 2$ enzyme, and an increase in proline, alanine, and glycine residues for thet -17 enzyme.

The $\mathrm{H}-17$ cyclomaltodextrinase gene was cloned on separate $\underline{\text { Pst }} 1$, Bam $\mathrm{H} 1$, and Eco R1 fragments in the plasmid vector pUC18, but was expressed in an inactive form in the host, E. coli DH5 $\alpha$. High level constitutive expression of the xiii 
gene product was also detrimental to the $E$. coli host, which led to structural instability of the recombinant plasmid. The cyclomaltodextrinase gene was then cloned on a $3 \mathrm{~kb} \underline{\text { Eco }} \mathrm{RI}$ fragment in the plasmid vector pPL708, and the fragment was structurally maintained in the host $B$. subtilis YB886. The cloned gene product appeared to be in an enzymatically active form in the B. subtilis host; however, expression was at a low level. 


\section{CHAPTER 1 INTRODUCTION}

One aspect in the evolution of biotechnology is the use of enzymes to replace chemical catalysts as the agents of chemical processes. The industrial hydrolytic depolymerisation of starch, once achieved by an acid-catalyzed process, is now achieved by starch-degrading enzymes, the amylases. Ironically, the first enzymes to be recognized as specific biocatalysts were those which could hydrolyze starch. Diastase, the active component of malt, was first isolated in France in 1833, and later shown to be a combination of $\alpha$ - and $\beta$-amylase [24]. In 1894, a mixture of amylases from Aspergillus oryzae was used by the Japanese as a digestive aid for the consumption of rice starch [24]. Historically, acid-catalyzed hydrolysis of starch to glucose was first conducted on an industrial scale in Germany, in 1850 [24]. It was not until the late 1960s that the traditional acid-catalyzed production of glucose was redesigned to an enzyme hydrolysis procedure on a commercial scale. This change was prompted by the breakthrough in the development of amyloglucosidase, which enabled starch to be completely degraded enzymatically to glucose. The advantages to an enzyme hydrolysis were higher yield, higher purity, and easier crystallization. The process was further developed in 1973 by introduction of a thermostable $\alpha$-amylase from Bacillus licheniformis. Starch liquefaction could now 
be rapidly achieved at $95^{\circ} \mathrm{C}$. followed by saccharification with amyloglucosidase, which enabled production of syrups containing up to $98 \%$ glucose. Today, the precise end-product composition can be controlled with different amylases, to give corn syrups having various levels of oligosaccharides, maltose, and glucose, with the desired chemical and physical properties. Furthermore, high glucose corn syrup may now be converted to the food system sweetener, high fructose corn syrup, by glucose isomerase $[20,24]$.

The use of the thermostable $B$. licheniformis $\alpha$-amylase at $95^{\circ} \mathrm{C}$ in the starch conversion process has several advantages, most notably a greater reaction rate, decreased risk of microbial contamination, lowered viscosity, and increased solubility of substrate and product. While liquefaction rapidly occurs within two hours at $\mathrm{pH} 6.5$, the conversion of maltodextrins to glucose or maltose syrups currently suffers several drawbacks. Saccharification by amyloglucosidase or $B$-(maltogenic) amylase requires a drop in temperature to $55-60^{\circ} \mathrm{C}$, and $\mathrm{pH}$ to $4.0-4.5$ or $5.0-5.5$, respectively. Furthermore, unacceptably long holding times for saccharification (48-96 h) are required to achieve maximal yields of glucose or maltose $[20,24,72]$. Therefore a new amyloglucosidase, $\alpha$-glucosidase, or maltogenic amylase with higher thermostability and $\mathrm{pH}$ optimum may have commercial applications following the partial hydrolysis of starch.

Since most commercial enzymes are of microbial origin, the development of industrially important thermostable enzymes has predominantly involved three 
approaches. One system employs screening multitudes of bacteria, usually thermophilic, for the production of a naturally occurring enzyme with high thermostability and pertinent biochemical characteristics. A second approach involves mutagenesis of the microorganism that produces minute quantities of a desired enzyme, such that expression of the enzyme's gene is derepressed and the enzyme is overproduced. The third technique is currently the most actively pursued among enzymologists and molecular biologists. The gene for a thermolabile enzyme is cloned, and specific amino acid substitutions are introduced into the enzyme by cassette mutagenesis of the gene. Theoretically, these amino acid alterations should produce additional intramolecular non-covalent or covalent interactions that will increase the enzyme's resistance to denaturation during elevated temperatures. Unfortunately, all three approaches are tedious, time consuming, and cost inefficient. In particular, site-directed mutagenesis requires knowledge of the enzyme's three dimensional structure through $x$-ray crystallography studies. The strategy then relies upon knowledge of the primary amino acid sequence, and the ability to predict which of 20 possible amino acid substitutions might result in an increase in enzyme thermostability, without sacrifice of catalytic efficiency.

A previously developed, unique procedure [39] may prove to be a viable alternative to achieving thermostability in commercially important, thermolabile enzymes. The approach involves the genetic conversion of a mesophilic strain to a thermophilic strain, by transforming the mesophile with a small fragment of 
genomic DNA from a thermophilic donor of the same genus. It should be stressed that only a small, but critical fragment of DNA is transferred, which induces wide pleiomorphic effects. The high temperature growth (HTG) transformants resulting from this genetic conversion are then evaluated for their ability to produce proteins and enzymes that are thermostable in vivo. Therefore, this method does not rely upon gene cloning to obtain knowledge of the primary amino acid sequence of the thermolabile enzyme; nor does it rely upon one's ability to predict amino acid substitutions that may result in increased enzyme thermostability. The strategy is to simply allow the intracellular biochemical processes of the HTG transformant to perform the subtle "work" necessary to convert all the cellular components, including enzymes, into thermostable macromolecules.

The overall aim of this dissertation was to screen a wide range of HTG transformants, generated from the mesophile Bacillus subtilis $25 \mathrm{~S}$, for their ability to produce various thermostable starch degrading enzymes. This evaluation involved searching for a possible glucogenic amylase that may have industrial value. After studying several glucan hydrolases produced by one HTG transformant, B. subtilis $\mathrm{H}-17$, an enzyme was chosen based on its ability to degrade maltodextrins. During this investigation, the enzyme was classified as a cyclomaltodextrinase. Within the overall aim was the biochemical, biophysical and genetic characterization of the cyclomaltodextrinase, and its comparison to the analogous enzymes from the mesophilic and thermophilic parents. 
The specific objectives to this study were as follows:

(a) To determine optimal growth conditions for maximal production of the cyclomaltodextrinase from B. subtilis $25 \mathrm{~S}$, B. caldolyticus $\mathrm{C} 2$, and B. subtilis H-17.

(b) To purify, characterize, and compare the thermostable cyclomaltodextrinase from $\mathrm{H}-17$ and the thermolabile cyclomaltodextrinase from $25 \mathrm{~S}$.

(c) To determine the possible molecular mechanism(s) which confer the thermostable properties of the H-17 cyclomaltodextrinase, based on structurestability relationships

(d) To determine if the donor, B. caldolyticus $\mathrm{C} 2$, also produces a thermostable cyclomaltodextrinase.

(e) To show that the $\mathrm{H}-17$ cyclomaltodexrinase is not a product of a specific thermophilic gene transferred from donor to recipient during transformation of $25 \mathrm{~S}$ to thermophily.

(f) To determine if the $\mathrm{H}-17$ cyclomaltodextrinase has advantages over currently used fungal amyloglucosidase or $B$-amylase for the industrial conversion of starch to glucose or maltose, respectively.

(g) To clone the $\mathrm{H}-17$ cyclomaltodextrinase gene and express its product in a suitable host.

(h) To determine the thermostability of the cloned $\mathrm{H}-17$ cyclomaltodextrinase gene product in a mesophilic host. 
The results would hopefully demonstrate the potential for development of thermostable starch-processing enzymes by the generation of HTG transformants from generally recognized as safe (GRAS) status Bacillus mesophiles. Furthermore, cloning the $\mathrm{H}-17$ cyclomaltodextrinase gene may allow a determination of its origin, and the molecular mechanism(s) which confer enzyme thermostability within the HTG transformants. 


\section{CHAPTER 2 \\ REVIEW OF LITERATURE}

\section{Thermophiles and Thermophily}

Temperature is one of the most important environmental factors that affects biological processes, the structure and metabolic function of cellular components, and the evolution of life. The majority of living organisms have adapted to a moderate environmental temperature near that of the Earth's surface average of $12^{\circ} \mathrm{C}[116,117]$. While the upper temperature limit for all living organisms is still unknown, it is assumed that all forms of higher organisms do not survive above $50^{\circ} \mathrm{C}$. In addition, no eukaryotic microorganisms are known to exist above $62^{\circ} \mathrm{C}$. Molds and yeasts are generally considered thermophilic if they grow as high as 40$50^{\circ} \mathrm{C}[11,83,116]$. However, in high temperature environments, many prokaryotic microorganisms have upper temperature limits greater than $60-70^{\circ} \mathrm{C}$. Thus far, only bacteria are able to adapt optimally to elevated temperatures. Bacterial growth in nature has been shown to occur from $-5^{\circ} \mathrm{C}$ to $100^{\circ} \mathrm{C}[83,116]$. The bacterial species diversity within a high temperature region is further influenced by other environmental parameters such as $\mathrm{pH}$, available energy sources, osmolarity, mineral content, and toxic metals. Examples of extreme thermal environments include terrestrial hot springs, deepsea hydrothermal vents, continental and submarine 
volcanic areas, small bays warmed by the sun, solar heated soil, thermally polluted streams, geothermal power plants, hot water storage tanks, and mechanical heating systems $[11,44,88,116]$. For bacteria living in regions of high environmental temperatures, molecular mechanisms of thermophily, and how such organisms evolved, have become a focal point of investigation.

Bacteria are usually classified into arbitrary groups based upon their preference to live within a limited temperature optimum for growth. Psychrophilic bacteria are capable of growth between $-5-25^{\circ} \mathrm{C}$. Mesophiles have temperature optima between $25-45^{\circ} \mathrm{C}$. Thermophilic bacteria show optimal growth between $45-100^{\circ} \mathrm{C}[115,116]$. Thermophiles may be further divided into (a) facultative thermophiles, which have an optimal growth temperature of $45-55^{\circ} \mathrm{C}$ but may grow at $25-30^{\circ} \mathrm{C}$, (b) obligate thermophiles, which have an optimal growth temperature of approximately $55-65^{\circ} \mathrm{C}$ but cannot grow below $40^{\circ} \mathrm{C}$, and (c) extreme thermophiles, which grow optimally above $70^{\circ} \mathrm{C}$ but cannot grow below $50^{\circ} \mathrm{C}$ $[28,79,108]$. However, one should be cautious when classifying according to growth temperatures since many microorganisms are borderline and could be assigned to either category depending upon growth conditions and the investigator's point of view.

In order to live optimally within their normal environmental temperature range, microorganisms must structurally adapt their proteins, nucleic acids, and lipids to function efficiently $[115,116]$. Since bacterial cells are essentially aqueous 
chemical systems, their viability may only be limited to temperatures at which water exists in a liquid state $[81,116]$. Indeed, microbial growth is thought to occur at temperatures greater than $100^{\circ} \mathrm{C}$, in which water remains in a liquid state under high pressure, for example, near deepsea hydrothermal vents [83]. However, every bacterial species has optimal growth within a relatively limited temperature range that rarely exceeds $30^{\circ} \mathrm{C}$. This environmental temperature regulates in the cell, not only the rates of enzyme catalyzed reactions, but also the structural state of water and of active biopolymers such as proteins, nucleic acids, and lipid membranes $[115,116]$. The structure and function of cellular biopolymers is based on the number and distribution of noncovalent bonds. Since these relatively weak bonds are essential for stability and function, then even slight inputs of thermal energy can disrupt noncovalent interactions which may lead to drastic structural and functional alterations [114]. To achieve thermoadaptation, it is reasonable to assume that the functional molecules of metabolism, and the structural molecules of cellular components have been adapted such that bacteria are designed to attain maximal metabolic efficiency at their optimal growth temperature $[115,116]$. Not only do cellular components of thermophiles become structurally thermostable, but thermophilic metabolism is based upon enzymes that have adapted to a high temperature optimum for biological activity [114]. 


\section{The Origin and Genetics of Thermophiles}

From an evolutionary standpoint, arguments regarding the origin of thermophiles have developed along two philosophies. The first, that thermophiles evolved from mesophiles by either adaptation or mutation is based upon the ubiquitous occurrence of thermophilic species in non-thermophilic environments [82]. If the thermostabilities of proteins and enzymes are encoded in their structural genes, then thermostability may be altered if a mutation occurs. Therefore, one could hypothesize that any type of microorganism could develop thermophilic properties if given sufficient time and opportunity. However, the conversion of a mesophile to a thermophile would require so many mutations that the probability of all these occurring in one cell is extremely small. Since the phylogenetic transition from a mesophile to a thermophile cannot be due to a spontaneous mutation of a single protein, it is improbable that acceptable mutations of most, if not all, enzymes and proteins could occur that would render a corresponding variation in thermostability and biological activity [114].

A more credible argument, that mesophiles originated from thermophiles, is based on speculation that the earliest cellular forms evolved in primordial waters considerably warmer than contemporary oceans or lakes [82]. The spontaneous transition between thermophilic and mesophilic bacilli, as observed in recent years, not only supports this second argument, but suggests that thermophilic properties 
are encoded in a small number of adaptor genes that control structure genes $[17,85,116]$.

Several attempts to identify the genetic determinant(s) of bacterial growth temperatures have implied that the transfer of a small number of genes may transform a mesophile into a thermophile, or vice versa. Cotransformation and cotransduction experiments in Bacillus subtilis $[47,48]$ demonstrated that the temperature sensitive locus (tms-26) is closely linked to the streptomycin region. The function of the $t m s-26$ marker in a high temperature growth $B$. subtilis mutant was to confer growth at $55^{\circ} \mathrm{C}$. Since genetic modification of the S-12 protein within the 30 s ribosomal subunit confers streptomycin resistance, the study suggests the tms-26 gene's involvement with ribosomal structure.

DNA studies $[12,18]$ of several related Bacillus species show that the region surrounding the streptomycin marker is highly conserved in base sequence. This conserved core of genetic material also includes genes which encode for ribosomal and transfer RNA's, and resistance to other antibiotics such as erythromycin and micrococcin. While there appears to be a gradient of conservatism, the results suggest the region to be relatively resistant to evolutionary change.

This high base sequence homology may have allowed recombination of a segment(s) of Bacillus caldolyticus DNA with the B. subtilis chromosome [39]. In a unique study, mesophilic B. subtilis (str ${ }^{\mathrm{s}}$, purA ${ }^{-}$[ade 16], growth optimum $37^{\circ} \mathrm{C}$ ) was transformed with purified genomic DNA from the obligate thermophile 
B. caldolyticus $\left(\right.$ str ${ }^{\mathrm{r}}$, pur $\mathrm{A}^{+}$[ade 16], growth optimum $\left.72^{\circ} \mathrm{C}\right)$. Str $^{\mathrm{r}}$, purA $^{+}$B. subtilis transformants were isolated that grew at $70^{\circ} \mathrm{C}$ and $55^{\circ} \mathrm{C}$ but not at $37^{\circ} \mathrm{C}$. Since the majority of genes encoding for antibiotic resistance, ribosomal proteins, rRNA, tRNA, and protein synthesizing components are located immediately following the purA gene in the early replicating region of the B. subtilis chromosome [64], the $s t r^{r}$ and purA ${ }^{+}$genes were assumed to be cotransformed with those encoding for ribosomal and tRNA functions. The study suggested that recombination of these genes into the host would induce wide pleiomorphic effects in which microbial stability is achieved by converting the entire cell of the mesophile into that of a thermophile. Specifically, alteration of the protein-synthesizing machinery at the tRNA or ribosomal level would produce translationally-modified enzymes and proteins with increased thermostability. To support their assertion, the researchers isolated L-histidinol dehydrogenase (HDH) from the thermophilic transformants. Compared to inactivation at $70^{\circ} \mathrm{C}$ of $\mathrm{HDH}$ from the recipient $B$. subtilis, the HDH's from several high temperature growth transformants were thermostable at $100^{\circ} \mathrm{C}$, whether assayed as crude extracts or as purified enzymes.

In a similar study [22], B. subtilis was transformed with DNA from Bacillus stearothermophilus or $B$. caldolyticus. High temperature growth transformants that grew at $65^{\circ} \mathrm{C}$ were isolated. The ribosomal proteins from the thermostable ribosomes of the transformants were analyzed using two-dimensional polyacrylamide gel electrophoresis. The gel patterns suggested that essentially all the genes that 
encode for ribosomal proteins were transferred from donor to recipient. However, the mechanism by which these and any other cotransferred genes exert microbial thermostability in the host has yet to be determined.

An alternative approach [17] screened for spontaneous thermotolerant mutant derivatives of mesophilic bacteria at $10^{\circ} \mathrm{C}$ above their upper growth limit. When prototrophic strains of B. subtilis and Bacillus pumilis were plated out in large numbers, thermophilic mutants that were able to grow between $50^{\circ} \mathrm{C}$ and $70^{\circ} \mathrm{C}$ were isolated at a frequency of $10^{-10}$. DNA from one thermophilic $B$. subtilis mutant was used to transform a mesophilic lys ${ }^{-}, \operatorname{trp}^{-}$B. subtilis auxotroph. Doubly-prototrophic $\left(\right.$ lys $\left.^{+}, \operatorname{trp}^{+}\right)$B. subtilis transformants were thermophilic, ie. grew between $50^{\circ} \mathrm{C}$ and $70^{\circ} \mathrm{C}$. The transformation frequency of the thermophilic trait was about $10^{-7}$, while the cotransformation frequency of the two unlinked prototrophic markers $\left(l y s^{+}\right.$, $\operatorname{trp}^{+}$) was also about $10^{-7}$. Since the transformation frequency of the thermophilic trait is similar to that for the transformation of two unlinked genes, the authors suggest that thermophily is the result of mutations in two unlinked genes. However, they do not speculate as to what those two genes are, and how close they are to the lys and trp markers. In a follow-up study [23], ribosomes from one of the spontaneous thermophilic B. subtilis mutants were thermostable at $60^{\circ} \mathrm{C}$ for 30 minutes, while ribosomes from the mesophilic parent were completely inactivated. Furthermore, the addition of polyamines to the cell-free extract from the thermophilic mutant stimulated polyphenylalanine synthesis at both $55^{\circ} \mathrm{C}$ and $65^{\circ} \mathrm{C}$, 
but inhibited protein synthesis with the cell-free extract from the mesophilic parent. The authors suggest, in the transition from mesophile to thermophile or vice versa, global mechanisms are in operation and that prime candidates may include genes encoding for polyamines, protein methylases, and DNA topoisomerases.

\section{Thermostability of Cell Components}

While the origin of thermophiles and their evolutionary relationship to mesophilic species within the same genus is by no means established, thermophilic and mesophilic microorganisms do seem to have a common origin $[44,114,115]$. Not only are thermophilic species found in most bacterial genera, but they resemble their mesophilic counterparts in that they ferment similar carbohydrates, utilize similar nitrogen sources, and have similar oxidative pathways. Cellular structures and sequence homologies of proteins, enzymes, and nucleic acids of thermophiles are also very much alike if not nearly identical to that of their mesophilic counterparts except that the former usually have much higher thermostabilities $[41,82,114]$.

With respect to mesophiles, several mechanisms have been proposed to explain the optimal growth and reproduction of thermophiles at high temperatures. Early theories attribute heat stability of thermolabile components to a) low cellular water content, b) transport of protective factors such as calcium from the environment into the cell, c) alteration in the nature of cell membranes, and d) 
rapid resynthesis of heat-denatured cell components [43,114]. Newer theories include a) synthesis of organic polymers, such as polyamines, that act as protector molecules, b) lipid interaction such that cell membranes stabilize heat labile macromolecules, and c) site-specific biochemical modification of macromolecules [58]. Perhaps there is no single mechanism that confers thermophily. Rather, a combination of molecular alterations allow optimal growth at elevated environmental temperatures. However, contrary to earlier theories, a massive turnover of cell components does not occur. Rather, thermophily is based on the thermostability of individual cellular components [90]. It now appears evident that structural comparisons of thermophilic and mesophilic nucleic acids, proteins, and lipids from closely related organisms can best provide a molecular explanation for the exceptional ability of thermophilic bacteria to live at high temperatures.

\section{Deoxyribonucleic Acid}

Studies $[79,87,104]$ concerned with the thermostability of DNA have compared the guanine plus cytosine $(\mathrm{G}+\mathrm{C})$ content and melting temperature of DNA isolated from thermophilic strains with that of mesophilic strains of the same genus. The DNA of thermophiles showed a consistently higher $\mathrm{G}+\mathrm{C}$ content than that of DNA from mesophiles. Thermal melting profiles demonstrated that thermophilic DNA had higher melting temperatures than DNA from mesophiles. The greater stability to thermal-induced strand separation is attributable to a more 
extensive hydrogen bonding that occurs with a higher $\mathrm{G}+\mathrm{C}$ content. Therefore, the $\mathrm{G}+\mathrm{C}$ content often correlates with maximum growth temperature, although Clostridium species are an exception. However, one cannot conclude that the thermostability of DNA, due to a higher $\mathrm{G}+\mathrm{C}$ content, has any relationship with the ability of a thermophile to grow at high temperatures.

\section{$\underline{\text { Ribonucleic Acid and Ribosomes }}$}

The base composition of messenger RNA (mRNA), isolated from the obligate thermophile $B$. stearothermophilus, was, as expected, nearly identical to the values obtained for DNA from the same organism [77]. As with DNA, it was concluded that the thermostability of mRNA probably does not play an important role in the ability of thermophiles to grow at high temperatures. Since active mRNA exists in a linear single stranded form, elevated growth temperatures should also have little or no effect on the secondary structure of mRNA, regardless of $\mathrm{G}+\mathrm{C}$ content.

The base compositions of transfer RNA (tRNA) from several strains of B. stearothermophilus have been shown to be very similar to that reported for the mesophile Escherichia coli. In addition, the thermal melting profiles of tRNA from B. stearothermophilus and $E$. coli were nearly identical $[19,43,104]$. The tRNA(Val) and tRNA(Phe) from B. stearothermophilus also reacted with the respective valine and phenylalanine-amino-acyl-tRNA synthetases from $E$. coli and yeast [43]. 
Consequently, it appears that tRNA structures are very similar, regardless of microbial source. However, the $\mathrm{G}+\mathrm{C}$ content of tRNA from the extreme thermophile Thermus aquaticus $(63.5 \%)$ was higher than that of either E. coli (59.5\%) or B. stearothermophilus (58\%) [113]. Furthermore, tRNA from $T$. aquaticus and E. coli had melting points of $86^{\circ} \mathrm{C}$ and $80^{\circ} \mathrm{C}$, respectively. Since $T$. aquaticus has a maximum growth temperature $11-17^{\circ} \mathrm{C}$ higher than that reported for strains of B. stearothermophilus, it is possible that the enhanced thermostability of $T$. aquaticus tRNA is a reflection of the greater $\mathrm{G}+\mathrm{C}$ content.

Related studies [101-103] have also shown that tRNA from the extreme thermophile Thermus thermophilus not only has a melting point higher than that from mesophiles, but has a high $\mathrm{G}+\mathrm{C}$ content $(90 \%)$ in the base paired region and a modified base, 5-methyl-2-thiouridine (or 2-thio-ribothymidine), instead of unmodified ribothymidine in the T-loop. Furthermore, when they compared the sequence of tRNA specific for formyl-methionine from $T$. thermophilus with that of E. coli, they found not only a $90 \% \mathrm{G}+\mathrm{C}$ content in the base-paired region of the thermophilic tRNA, but that a G-U pair in E. coli tRNA was replaced by a G-C pair in the $T$. thermophilus tRNA. The results indicate that thermophilic tRNA(fMet) is thermally stabilized by formation of an extra intramolecular hydrogen bond when a uridyl residue is replaced with a cytydyl residue, and by increased stacking interaction due to thiolation of a ribothymidine residue. Although the changes are quite subtle, they are located in a region quite distant 
from the anticodon loop and amino acid accepting terminal, both of which are important for tRNA function.

Reviews $[19,43,90,104]$ indicate a variety of conflicting results regarding the effect of ribosomal RNA (rRNA) $\mathrm{G}+\mathrm{C}$ content and melting points on the thermostability of ribosomes. The thermal melting profiles of ribosomes have shown that ribosomes from thermophiles undergo thermal denaturation at higher temperatures than ribosomes from mesophiles, perhaps due to the increase in $\mathrm{G}+\mathrm{C}$ content of rRNA from thermophiles. Elucidation of the molecular basis of ribosomal thermostability remains unclear. Although the rRNA nucleotide composition may play a significant role, the same authors $[19,43,90,104]$ agree that other factors such as primary structure of ribosomal proteins, the stacking arrangement of ribosomal protein and rRNA, and the association of polyamines with ribosomes, are probably more important in the stability of ribosomes in thermophiles. Specific polyamines, such as the tetramine spermine and the triamine spermidine, both synthesized by $B$. stearothermophilus, have been shown to aid in the association of ribosomal subunits at high temperatures [43,56]. More than 12 distinct polyamines, $\mathrm{NH}_{2}\left(\mathrm{CH}_{2}\right)_{3}\left[\mathrm{NH}\left(\mathrm{CH}_{2}\right)_{3}\right]_{x} \mathrm{NH}\left(\mathrm{CH}_{2}\right)_{4} \mathrm{NH}_{2}$, were also isolated from T. thermophilus $[56,59]$. The tetramines, thermine and thermospermine were the main forms, while the pentamines, caldopentamine and homocaldopentamine, and hexamines, caldohexamine and homocaldohexamine were also present. Thermine or thermospermine were shown to initiate and maintain polyphenylalanine synthesis 
directed by polyuridylic acid at high temperatures $\left(50-80^{\circ} \mathrm{C}\right)$. When the $\operatorname{RNA}(\mathrm{Phe})$, polyuridylic acid, and ribosomes were incubated at high temperature in the absence of the polyamine, a ribosome-mRNA-amino-acyl-tRNA ternary complex also formed but was inactive. The results indicate that during protein synthesis, thermine and thermospermine may play an in vivo role in the initial formation of the active ternary complex between ribosomes, mRNA, and amino-acyl-tRNA at high temperatures.

Thermine was also found in the extreme thermophiles T. aquaticus and Thermus flavus, while no detectable amount of thermine occurred in the obligate thermophile B. stearothermophilus [56]. It appears that, not only thermine and thermospermine, but other novel polyamines such as caldine and sym-homospermidine occur only in extreme thermophiles, which implies their involvement in extreme thermophily [57]. Although not yet understood, these unusual polyamines may also play important roles in other biochemical reactions such as DNA replication, transcription, and cell division, besides just translation.

\section{Lipids and Cell Membranes}

The central structural feature of microbial membranes is the phospholipid bilayer, which consists of peripheral proteins bound to the polar portion of the lipid bilayer, and integral proteins embedded within the nonpolar portion of the lipid bilayer $[43,49,105]$. A unique feature of the phospholipid bilayer is its ability to 
undergo a reversible phase transition from a thermotropic gel (solid) to a liquidcrystalline state [49]. In the gel or solid state, the fatty acyl chains form a close hexagonal packing, which results in a restricted inter and intramolecular motion, and a rigid, somewhat impermeable bilayer structure. During the gel to liquidcrystalline transition, selective melting of the phospholipid hydrocarbon chains in the interior of the bilayer occurs. However, the transition is not sharp but broad due to heterogeneity of fatty acyl chains, which results in simultaneous domains of gel and liquid-crystalline phases. In the liquid-crystalline state, although the hydrocarbon chains are in a partially melted condition, the bilayer structure is maintained by electrostatic interactions between polar head groups and hydrophobic forces, which allows for a loosely packed, fluid, and somewhat permeable bilayer structure [49]. Consequently, cell membranes must be in the liquid-crystalline state such that transport functions, and activity of membrane-associated enzymes ensure cell growth [43].

The temperature range at which the gel to liquid-crystalline transition occurs depends upon the nature of the fatty acyl content of membrane lipids. It is generally accepted that most microorganisms alter their membrane lipid composition in response to a change in environmental temperature. The membranes of thermophiles have shown a higher content of apolar fatty acyl residues with higher melting temperatures than the residues of psychrophilic and mesophilic microorganisms. This would minimize the effect of high environmental temperature 
on the physical state of the membrane lipids by raising the temperature of the gel to liquid-crystalline phase transition. Therefore, when thermophilic bacteria adapt to increases in cultivation temperature, their membranes shift to a higher proportion of longer, saturated fatty acids, and monomethyl-branched chains, and to a decreased proportion of unsaturated fatty acids $[36,43,49,67,70,104,105]$. As a general trend, the iso- and anteiso-monomethyl-branched chains tend to be the predominant form of apolar fatty acyl residues in thermophilic bacteria. However, in nearly all thermophiles examined, the majority, if not all, of the complex (polar) lipids contain a carbohydrate residue. It appears that lipids enriched in carbohydrates usually form the major lipid class, which implies a significant role in membrane thermostability [36,90]. Although not well understood, analysis of lipids from thermophiles suggest general trends in which there may be a combined variety of strategies for the molecular basis of thermostable membranes.

\section{$\underline{\text { Proteins and Enzymes }}$}

Proteins have a limited temperature range within which structural integrity is maintained. All known proteins (enzymes) unfold, denature and thereby lose biological activity upon a certain intensity of thermoexposure. A thermophilic enzyme is more thermostable at higher temperatures, but less active at lower temperatures than a mesophilic enzyme. Thermostable enzymes from thermophiles, compared to thermolabile enzymes from mesophilic species of the same genus, 
resist thermal unfolding at elevated temperatures due to differences in the number, strength, and distribution of their intramolecular noncovalent forces $[32,50,99,117]$. Therefore, the primary structure of an enzyme ultimately determines the number and type of noncovalent interactions. Amino acid sequence analysis of several mesophilic enzymes and their thermophilic counterparts has shown that a few specific amino acid substitutions at critical regions may account for very subtle structural and conformational differences that lead to large alterations in thermostability $[2,32,99,117]$. That is, a gain in thermostability of an enzyme usually does not require a drastic or extreme structural rearrangement in its conformation, but does require structural maintenance of its catalytic site. An enzyme from a thermophile consistently shows the same structural characteristics such as polypeptide chain length, secondary structure, catalytic site, globular domains, subunit structure, and modulation of activity by metal ions and effectors, as does the same enzyme isolated from a mesophile of the same genus $[52,86]$.

Probably the most important, if not decisive, mechanism that confers protein thermostability is hydrophobic interaction $[3,50,99]$. The total hydrophobic amino acid content of a thermophilic enzyme, and that of its mesophilic counterpart, may or may not greatly differ. Rather, thermostability depends upon an increased proportion of hydrophobic residues around the active site. The overall effect is a greater internal and decreased external hydrophobicity. Therefore, strengthening of the internal nonpolarity is achieved by substitution of specific amino acid 
residues, characteristic of mesophilic enzymes, with aliphatic amino acids, with retention of the overall structure and catalytic properties. As a result, internal hydrophobic domains contribute to compact packing of amino acid residues. A compact globular structure excludes water from internal cavities, which allows for improved enzyme stability.

A second factor that confers protein thermostability is the formation of additional electrostatic interactions such as divalent cation salt bridges and ion pairs $[50,62,63,99]$. Since electrostatic interactions are formed between negatively-charged aspartate and glutamate residues and positively-charged lysine, histidine, and arginine residues, then a greater proportion of these residues in a thermophilic enzyme may account for a higher thermostability than that of its mesophilic counterpart. Furthermore, thermophilic enzymes frequently have higher levels of arginine relative to lysine and histidine. Because the pKa's for lysine and histidine are lower than the $\mathrm{pKa}$ for arginine, at alkaline $\mathrm{pH}$ values, lysine and histidine side chains will dissociate and electrostatic interactions will be disrupted. Greater thermostability results from stronger electrostatic interactions formed by arginine rather than lysine or histidine [32].

A third molecular mechanism that enhances enzyme thermostability is an increase in intramolecular hydrogen bonds $[50,99]$. A comparison of thermophilic ferredoxins and hemoglobins with mesophilic counterparts concluded that thermostability is increased by the formation of a few new hydrogen bonds and salt 
bridges [63]. In addition, 19 additional hydrogen bonds were detected in thermophilic protease, which were absent in the mesophilic enzyme [54]. It appears that an alteration in the number of hydrogen bonds sometimes induces a change in the secondary structure of thermophilic enzymes compared with their mesophilic counterparts. However, some thermophilic proteins lack polar amino acids, mostly serine and threonine [50]. Assuming a high degree of internal hydrophobicity, internal localization of serine and threonine is thermodynamically unfavorable. The substitution of internal serines and threonines with nonpolar residues theoretically increases thermostability. Therefore, in some thermophilic proteins, intramolecular hydrogen-bonding may be assumed to be localized at the surface of the molecule. Similarly, in an enzyme's compact interior, all polar groups are hydrogen-bonded and that alteration of size, shape, or polarity of a single side chain could destabilize enzyme structure [86]. Since water mobility presents little barrier to intramolecular hydrogen bonding alterations between surface residues, an increase in polar and a decrease in nonpolar surface residues could enhance thermostability.

Other factors that enhance protein thermostability include the formation of intramolecular disulfide bonds, substrate binding, and post-translational modification such as glycosylation or chemical modification of key surface groups [50,52,99]. However, one enzyme's mechanism of thermostability may be different from another's. Thermostabilization may also be attributable to the simultaneous contribution of several different mechanisms. Consequently, interpretation often 
becomes complex and even contradictory when comparing structural mechanisms of thermostability among different thermostable enzymes. Rather than present a comprehensive review of all comparisons between thermostable enzymes and their mesophilic counterparts, only a few significant studies will be presented in which the factors that confer thermostability are somewhat understood.

The complete lactate dehydrogenase ( $\mathrm{LDH}$ ) primary sequences from the thermophiles Bacillus caldotenax, B. caldolyticus, and B. stearothermophilus, the mesophiles Bacillus megaterium, and B. subtilis, and the psychrophile Bacillus psychrosaccharolyticus underwent an extensive comparative structural analysis $[25,115,117]$. The sequence homology between the LDH variants was between $60 \%$ and $70 \%$. Specific temperature-related amino acid substitutions occurred in which polar amino acids, particularly serine and threonine, in the mesophilic (psychrophilic) enzymes are exchanged for hydrophobic and charged residues, particularly alanine, arginine, and aspartate in the thermophilic enzymes. These substitutions did not occur among thermophilic or among mesophilic LDH variants, which contrasts to the 12-13 substitutions between thermophilic and mesophilic LDH. Three-dimensional structure analysis of all the LDH variants indicated that most of the substitutions were buried in the same strategically important regions, particularly near the active site and in contact regions of the subunits. This indicates that there are apparent regions of significant importance in temperature adaptation. Furthermore, in the transition of mesophilic (psychrophilic) to 
thermophilic LDH, a dynamic hydrogen bond system is converted to hydrophobic interactions or ion pairs in which the free energy of the enzyme is increased. Conversely, in the transition of thermophilic to mesophilic (psychrophilic) LDH, a reduction in energy-yielding hydrophobic interaction and ion pairs occurs in favor of hydrogen bonding. The author concluded that, at high temperatures, the preferred thermophilic residues of thermophilic LDH should increase thermostability, but produce a more rigid and less active structure at low temperatures. However, polar residues, perhaps hydrated, should lead to a more dynamic, flexible, and active structure at low temperatures, but a labile structure at high temperatures. These temperature-related amino acid substitutions are stored in the structure of the genetic code, and hence are based on evolutionary temperature-related base substitutions.

The genes for alanine dehydrogenase were cloned and sequenced from the mesophile Bacillus sphaericus and B. stearothermophilus [34]. A comparison of the primary amino acid sequences showed a $73 \%$ homology, with the non-identical residues clustered in a few regions of relatively short length. The residues involved in catalysis and coenzyme binding were conserved in a sequence of high homology ( $>80 \%$ ), while the short sequences of low similarity were believed to contribute to the thermostability of the $B$. stearothermophilus enzyme. An additional cysteine in the B. stearothermophilus alanine dehydrogenase may form an interior disulfide bond with one of two nearby cysteines, which may enhance thermostability. 
The oligo-1,6-glucosidases from Bacillus cereus (mesophile), Bacillus coagulans (facultative thermophile), Bacillus sp. KP1071 (facultative thermophile), Bacillus thermoglucosidasius (obligate thermophile), and Bacillus flavocaldarius (extreme thermophile) were compared for amino acid composition, structural parameters, and thermostability [95]. Results showed that the proline content greatly increased in a linear fashion with the increase in thermostability among all five enzymes. The hydrophobic residues, in particular alanine and leucine, also showed upward tendencies in parallel with the increase in thermostability, while polar residues showed downward trends. Although the enzymes were quite similar in terms of structural parameters, the content of $\alpha$-helix formers decreased with an increase in thermostability, while $\beta$-sheet formers remained nearly constant. The increase in proline, an $\alpha$-helix breaker, could contribute to improved turn stabilization. While this may increase the disordered regions at the expense of helix formations, it could produce a greater potential for close packing of hydrophobic regions. The strengthened hydrophobic interactions would tighten the molecule as a whole and thereby enhance thermostability.

The thermostable $\alpha$-amylase from $B$. stearothermophilus was compared to the thermolabile $\alpha$-amylase from B. subtilis [111]. Results indicated that binding of calcium ions to both mesophilic and thermophilic $\alpha$-amylase considerably enhances the stability of the native conformation of both enzymes. However, calcium-free thermophilic $\alpha$-amylase was very susceptible to thermal denaturation, but was more 
resistant to heat than calcium-free mesophilic $\alpha$-amylase. This suggests differences in the amino acid sequence between the two proteins. It was concluded that the difference in thermostability of $\alpha$-amylase from B. stearothermophilus and B. subtilis is caused by the difference in the enzyme's affinity to the calcium ion at elevated temperatures, which may be a function of amino acid sequence.

The liquefying $\alpha$-amylases produced by Bacillus licheniformis, Bacillus amyloliquefaciens, and B. stearothermophilus contained highly homologous amino acid sequences, with a $64 \%$ homology between the B. stearothermophilus and B. amyloliquefaciens enzymes, a $67 \%$ homology between the B. stearothermophilus and $B$. licheniformis enzymes, and an $80 \%$ homology between the $B$. licheniformis and $B$. amyloliquefaciens enzymes [26]. Because the regions of extensive homology include active sites, they probably are required for maintaining protein conformation and enzymatic activity. Furthermore, the thermostable B. stearothermophilus $\alpha$-amylase contained two cysteine residues located near the enzymatically functional region, while the thermolabile $B$. amyloliquefaciens enzyme contained no cysteine residue. The formation of a disulfide bridge between the two cysteine residues could account for thermostability in the B. stearothermophilus $\alpha$-amylase. However, the structural differences in non-homologous regions of the three $\alpha$-amylases are presumed to be responsible for differences in thermostability [112]. Because the hydropathy profiles of all three enzymes were significantly hydrophilic, the authors 
suggested that salt bridges between charged and polar amino acids within nonhomologous regions may account for thermostability of the $\alpha$-amylases.

\section{Protein Engineering of Industrially Important Enzymes}

The current total world market for industrial enzymes is over 500 million dollars per year. About 20 microbial enzymes account for the majority of this market. Microbial enzymes applied to food processing and industrial operations include protease, $\alpha-, \beta-$, and gluco-amylase, pullulanase, glucose isomerase, cellulase, hemicellulase, lipase, pectinase, lactase, and alcohol dehydrogenase [14,52,83]. Where possible, thermostable enzymes are now utilized extensively for industrial processing. Adequate thermostability of commercial enzymes may be defined as retention of enzyme activity upon exposure to temperatures of $50^{\circ} \mathrm{C}$ or above, for prolonged periods [50,99]. Their industrial application may be advantageous for several reasons $[32,52,84,99]$ : (a) Higher reaction rates can be obtained, since for every $10^{\circ} \mathrm{C}$ increase in temperature, reaction rates approximately double. Consequently, for each $10^{\circ} \mathrm{C}$ increase in operating temperature, the holding times can be shortened, or the amount of enzyme required for a given conversion can be theoretically halved. (b) Microbial contamination of enzyme reactions lasting several days is less likely to occur at operation temperatures of $60^{\circ} \mathrm{C}$ or greater. (c) At elevated temperatures, higher reactor productivity may be achieved due to greater solubility of reactants, reduced viscosity, and improved mass transfer rate. 
(d) Enzymes of high thermostability often show increased resistance to chemical denaturation and thus longer shelf lives.

One factor that limits commercial enzyme application is the high cost of isolating and purifying sufficient amounts of the enzyme. A second limitation is that, while enzymes have evolved to function optimally under normal physiological conditions, they may not function under nonphysiological industrial conditions that include extremes of $\mathrm{pH}$, ionic strength, oxidation, and temperature $[27,52,97]$. Consequently, robust enzymes with longer half-lives under process conditions are required for industrial applications. As a solution, genetic engineering techniques have attempted to the improve production of commercial enzymes by (a) amplification of the production of specific enzymes by mutation of microorganisms, (b) cloning and synthesis of enzymes in Generally Recognized As Safe (GRAS) organisms, and (c) protein engineering by genetic modification (mutagenesis) in which enzyme structure is altered such that one or more functional properties are improved under nonphysiological, extreme conditions, that is, high temperatures.

The major cost savings resulting from the benefits of thermostable enzymes currently prompt the development of thermostable properties to be engineered into enzyme molecules based on structure-stability relationships. Specifically, one goal of protein engineering is to enhance the thermostability by genetically introducing new noncovalent and/or covalent bonds within the enzyme. Genetic modification 
may involve several techniques $[65,99,107]$. One approach relies upon knowledge of the enzyme's three-dimensional structure by high resolution $\mathrm{x}$-ray crystallography and computer analysis, which delineates possible amino acids responsible for thermal sensitivity [1]. Variant amino acid sequences may then be designed by sitedirected mutagenesis of the cloned gene encoding for the enzyme, so that specific nucleotide substitutions are created. Alternatively, cassette mutagenesis may achieve the same substitutions utilizing synthetic oligonucleotides. Restriction and ligation enzymes are employed to replace any sequence of the cloned gene with the synthetic fragment carrying one or more specific nucleotide substitutions (or deletions/insertions). The recombinant plasmid is then transformed into the appropriate host and transformants are screened for production of thermostable enzyme. However, either approach may (a) be time consuming due to the substitution of many possible amino acids at each site of interest, and (b) cause destabilization due disruption of pre-existing stabilizing interactions.

At Genex Corp., site-directed mutagenesis has successfully introduced a disulfide bond into subtilisin BPN, the alkaline protease secreted by B. subtilis [60]. While this enzyme has no pre-existing cysteine residues in the wild type structure, cysteine substitutions at Thr-22 and Ser-87 positions generated a Cys-22/Cys-87 disulfide subtilisin variant that had catalytic activity essentially equivalent to that of the wild-type enzyme. The disulfide variant, expressed in subtilisin-negative B. subtilis, had a melting temperature of $3.1^{\circ} \mathrm{C}$ higher than that of the wild type 
protein and $5.8^{\circ} \mathrm{C}$ higher than that of the reduced form (-SH HS-) of the variant. Furthermore, under a variety of kinetic conditions, the disulfide variant underwent thermal inactivation at half the rate of that of the wild-type enzyme.

Conversely, a related approach, which employs random mutagenesis of the cloned gene, can unpredictably create new and interesting enzymes that may have novel properties, including increased or decreased thermostability. The key element to this approach is the ability to screen large numbers of variants for increased thermostability. The same researchers at Genex Corp. [69] used chemical mutagenesis to introduce random mutations into the cloned subtilisin gene, and transformed the recombinant plasmids into subtilisin-negative $B$. subtilis. A chromogenic substrate activity stain of a nitrocellulose bacterial colony lift was employed to isolated ten enzyme variants with increased resistance to thermal inactivation. All the variants were the result of a single amino acid substitution due to a point mutation. One variant enzyme had more than a four-fold thermal resistance at $65^{\circ} \mathrm{C}$. A single amino acid substitution of serine for asparagine at position 218 was present in the variant protease. The mutation, which occurred at one end of a B-hairpin structure, caused shortening of hydrogen bonds across the chains of the hairpin [106]. A triple combination mutant was then constructed from this Asn-218 to Ser variant by using oligonucleotide-directed cassette mutagenesis. The addition of Gly-131 to Asp, and Thr-254 to Ala mutations increased the variant's $t_{1 / 2}$ of thermal inactivation at $65^{\circ} \mathrm{C}$ to 11.6 -fold over that of the wild-type, 
without alteration of catalytic properties. Therefore, minor independent alterations in amino acid sequence dramatically increased thermostability without radical changes in the tertiary protein structure.

The genes for the neutral protease from B. stearothermophilus and B. caldolyticus have been cloned and sequenced [98]. A comparison of the derived primary amino acid sequences showed both enzymes to differ at only three amino acid positions, 4, 59, and 66. Furthermore, the B. caldolyticus enzyme had a thermostability and temperature optimum of 7 to $8^{\circ} \mathrm{C}$ higher than that of the B. stearothermophilus enzyme. Using cassette mutagenesis, the substitutions Ala-4 to Thr, Thr-59 to Ala, and Thr-66 to Phe were introduced into the B. stearothermophilus enzyme. The mutation Thr-66 to Phe increased thermostability by $6.2^{\circ} \mathrm{C}$, while the mutations Ala- 4 to $\mathrm{Thr}$ and $\mathrm{Thr}-59$ to Ala increased thermostability by 1.75 and $1.5^{\circ} \mathrm{C}$, respectively. While the thermostability of the triple mutant theoretically should have been $9.45^{\circ} \mathrm{C}$ higher, it was only equivalent to that of the wild-type $B$. caldolyticus neutral protease. A threedimensional model of the variant enzyme showed the substituted residues to be surface located. The results indicated that solvent-exposed residues may be important in conferring thermostability to neutral proteases, even though two hydrophilic residues were replaced with hydrophobic residues.

Oligonucleotide-directed mutagenesis of the $\alpha$-amylase from B. amyloliquefaciens deleted the Arg-176 and Gly-177 residues, and substituted GIn 
for Glu-178 and Ala for Lys-269 [109]. Results showed the variant enzyme to be as thermostable as the $\alpha$-amylase from $B$. licheniformis, that is, more than $80 \%$ retention of activity after $30 \mathrm{~min}$ at $90^{\circ} \mathrm{C}$. However, the variant enzyme demonstrated a kinetic temperature optimum of $65^{\circ} \mathrm{C}$, which suggested reversible inactivation at temperatures above $65^{\circ} \mathrm{C}$.

Oligonucleotide-directed mutagenesis was also employed to introduce single point mutations in the cloned lactate dehydrogenase (LDH) genes from B. megaterium and B. stearothermophilus [118]. The substitutions of Thr-29 or Ser-39 to Ala residues in the mesophilic LDH from $B$. megaterium increased the enzyme's thermostability by $15^{\circ} \mathrm{C}$. When alanine was simultaneously introduced at both positions, a $20^{\circ} \mathrm{C}$ increase in thermostability was observed. The authors suggest that the more helix-forming alanine residues stabilize the $\alpha$-B helix of LDH, and serve to exclude water molecules across the Q-axis between the subunit $\alpha$-helices. Unfortunately, an increase in $\mathrm{K}_{\mathrm{m}}$ for pyruvate resulted, which led to a three-fold reduction in activity when compared to the wild type enzyme. The reverse double substitutions, Ala-29 to Thr and Ala-39 to Ser, in thermophilic LDH from B. stearothermophilus, did not alter the high thermostability. However, the LDH activity of this variant was increased two-fold. The results indicate the stability and activity of the $B$. stearothermophilus and $B$. megaterium LDH to be based on a highly cooperative system of noncovalent bonds which is influenced differentially by amino acid substitutions. 
A third approach to genetic modification of enzymes involves isolation of enzyme variants without structural information on the wild type protein. A gene encoding an enzyme from a mesophile is cloned, introduced into a thermophilic host, and enzyme activity is selected at the higher growth temperature of the host. The cloned gene for mesophilic kanamycin nucleotidyltransferase (KNTase) was introduced into B. stearothermophilus, and kanamycin resistant transformants were selected at $63^{\circ} \mathrm{C}$ [37]. All the purified $\mathrm{KNTase}$ variants were more thermostable than the wild type enzyme, and all had the same single amino acid replacement of Asp- 80 to Tyr. Variants even more thermostable were obtained from the first variant by selecting for B. stearothermophilus kanamycin resistance at $70^{\circ} \mathrm{C}$. All these Tyr- 80 variants carried the same additional substitution of Thr-130 to Lys. The authors suggest that the alterations at positions 80 and 130 act independently and additively to thermostabilize KNTase. Furthermore, all the KNTase variants had specific activities equivalent to that of the wild type enzyme. The advantage to this technique is that, by selecting for enzyme activity, thermostable variants are generated in which enhancement of stability was not made at the expense of catalytic efficiency. This biological selection strategy accounts for all variables of activity and structural stability simultaneously. As thermophilic host-vector cloning systems are further developed, the strategy can be readily extended to other mesophilic genes of greater industrial value. 
Another approach to achieving enzyme thermostability involves conversion of the entire cell of a mesophile into that of a thermophile [39]. Although less well studied, potentially any mesophile, producing a thermolabile enzyme(s) of commercial interest, could be converted to a thermophile by transforming it with DNA from a related thermophilic species. This method does not rely upon structural knowledge of the mesophilic enzyme, nor does it rely upon one's ability to predict appropriate amino acid substitutions. The high temperature transformant carries out all the necessary changes to convert a thermolabile enzyme to a thermostable form. Another advantage is that it does not rely on gene cloning, mutagenesis, transformation, and screening for expression of the variant cloned gene. In theory, the transfer of a small number of genes to the mesophile would exert wide pleiomorphic effects in which translationally modified proteins are produced with increased thermostability.

\section{Microbial Amylases in Starch Bioprocessing}

Amylases are starch degrading enzymes that have several industrial applications in the production of corn syrups that contain varied amounts of maltooligosaccharides, maltose, and glucose. Although amylases are widely distributed in nature and are produced by a variety of microorganisms, most commercial amylases are produced from Bacillus species. The composition profile of the corn syrup produced from starch hydrolysis depends upon the nature of the amylase, and 
the reaction conditions employed. The three basic types of amylolytic enzymes used in starch conversion are (a) endo-amylase ( $\alpha$-amylase) (b) exo-amylase ( $\beta$-amylase and glucoamylase) and (c) debranching enzyme (pullulanase and isoamylase). $\alpha$-Amylases hydrolyze the internal $\alpha-1,4$-glucosidic bonds in amylose and amylopectin to produce short-chained maltodextrins, but the $\alpha$-1,6-glucosidic branches in amylopectin are not attacked. Depending on the length of malto-oligosaccharides produced and the source of enzyme, $\alpha$-amylases are further classified as saccharifying or liquefying. For example, the B. subtilis saccharifying enzyme produces large quantities of maltotriose, a slow decrease in starch viscosity, and a rapid increase in reducing power, while the $B$. amyloliquefaciens liquefying enzyme produces mainly maltohexaose, with a slower increase in reducing power but a rapid decrease in starch viscosity. Because of their extremely high thermostability $\left(85^{\circ} \mathrm{C}\right.$ $100^{\circ} \mathrm{C}$ ), the $\alpha$-amylases from $B$. licheniformis and B. amyloliquefaciens are the most commercially significant and most widely employed $[9,20,21,72]$.

Glucoamylase and B-amylase act in exo-fashion by consecutively cleaving glucose and maltose units, respectively, from the non-reducing ends of amylose, amylopectin, and maltodextrins. Although all commercial glucoamylases are of fungal origin and have low thermostability $\left(40^{\circ} \mathrm{C}-60^{\circ} \mathrm{C}\right)$, they are used for the production of high glucose syrups subsequent to starch liquefaction. B-amylase, which produces maltose in the $B$-anomeric form, is found widely in higher plants. However, several bacteria, including B. polymyxa, B. megaterium, and B. circulans, 
produce B-amylases similar to those of plant origin. Although bacterial B-amylases are also of low thermostability $\left(40^{\circ} \mathrm{C}-60^{\circ} \mathrm{C}\right)$, their industrial application is in the production of high maltose syrups in excess of $80 \%$ maltose $[9,20]$.

The industrially-employed Klebsiella pneumoniae or Bacillus acidopullulyticus pullulanase catalyses the hydrolysis of $\alpha-1,6$-glucosidic linkages in amylopectin and pullulan to produce linear maltodextrins and maltotriose, respectively. Because it also has low thermostability $\left(45^{\circ} \mathrm{C}-60^{\circ} \mathrm{C}\right)$, it generally is used in combination with glucoamylase or B-amylase to improve the yields of syrups high in glucose or maltose, respectively $[9,20,72]$. Recently, novel highly-thermostable $\left(>90^{\circ} \mathrm{C}\right)$ pullulanases have been isolated from thermophilic anaerobic bacteria. Although these enzymes cleave the $\alpha-1,4$-glucosidic linkages of starch, they are classified as either isopullulanase or neopullulanase based on their hydrolysis of $\alpha-1,4$ linkages of pullulan to produce isopanose or panose, respectively $[72,81]$.

The industrial conversion of starch to glucose or maltose syrups currently suffers several drawbacks $[20,21,72]$. While liquefaction rapidly occurs within 2 hours at $95^{\circ} \mathrm{C}, \mathrm{pH} 6.5$, saccharification requires a drop in temperature to $55^{\circ} \mathrm{C}-60^{\circ} \mathrm{C}$, and $\mathrm{pH}$ to $4.0-4.5$ (glucoamylase) or 5.0-5.5 (B-amylase). Furthermore, the saccharification step requires a $48-96$ hour holding time in order to achieve maximal levels of glucose or maltose. Other problems include the formation of reversion products and the possibility of microbial growth at the lower saccharification temperature $[20,72]$. Consequently, the development of glucogenic, 
maltogenic, and debranching enzymes with exceptionally high thermostabilities and more neutral $\mathrm{pH}$ optima would make industrial starch processing more costefficient. Ideally, the production of corn syrups would be a single step process in which liquefaction, debranching, and saccharification occur simultaneously. Furthermore, these enzymes must be produced from microorganisms that have GRAS status by the Food and Drug Administration. To this end, protein engineering techniques of starch degrading enzymes may eventually produce variant enzymes with the desired catalytic properties that will optimize any type of starch conversion process.

\section{$\underline{\text { Bacterial Cyclomaltodextrinases }}$}

Many amylolytic microorganisms capable of catalyzing the hydrolysis of starch by the production of $\alpha$-amylases, also produce intracellular and extracellular maltodextrinases and $\alpha$-glucosidases. These latter enzymes play an essential role in the microbial conversion of starch to glucose, by hydrolyzing maltodextrins and maltose produced from amylolytic hydrolysis of $\operatorname{starch}[4,20,91,96]$. Several bacterial species also produce cyclomaltodextrinases (CDase) (EC 3.2.1.54), which rapidly cleave cyclodextrins and linear maltodextrins, but hydrolyze starch at significantly slower rates $[30,31,53]$. Cyclodextrins (CDs) are cyclic oligosaccharides composed of six $(\alpha-C D)$, seven (B-CD), eight ( $\gamma-C D)$, or more $\alpha$-linked glucose units. Because CDs lack terminal non-reducing glucose residues, they resist the hydrolytic action 
of exo-amylases. They may competitively inhibit many $B$-amylases and pullulanases. Due to their cyclic nature, they are very slowly cleaved, if at all, by endo-amylases $[20,51,71,89]$. Consequently, CDases appear to be a separate, special amylase class in which they often share common biochemical characteristics, substrate specificities, and end-product profiles.

The purified cyclodextrinase from $B$. coagulans had a molecular weight, as determined by SDS-PAGE, of 62,000, and an isoelectric point of 5.0 [31]. The enzyme optimal activity at $\mathrm{pH} 6.2$ and $50^{\circ} \mathrm{C}$, and was thermostable at $45^{\circ} \mathrm{C}, \mathrm{pH} 7.0$ for two hours. The enzyme hydrolyzed maltotetraose, maltopentaose, maltohexaose, and $\alpha-, \beta-$, and $\gamma, C D$ saster than maltotriose and short chain amylose, but did not cleave maltose. The enzyme recognized and cleaved the $\alpha$-maltosyl group in the non-reducing end [30]. The hydrolysis products had the $\alpha$-configuration and were mainly maltose. Starch, amylose, and amylopectin were hydrolyzed at rates $1 \%$ that for $B-C D$.

The intracellular cyclodextrin-hydrolyzing enzyme from B. sphaericus was purified and estimated to be a homodimer having a native molecular weight of 144,000, and subunit molecular weight of 72,000 [53]. The enzyme had a pH optimum of 8.0 , was stable at $25^{\circ} \mathrm{C}, \mathrm{pH} 5.5-9.5$ for 24 hours, and was inactivated at $50^{\circ} \mathrm{C}$ for 10 minutes. The enzyme most rapidly hydrolyzed $\mathrm{B}-\mathrm{CD}$, followed by maltoheptaose, maltopentaose, $\alpha-C D$, and maltohexaose. Starch, amylopectin, amylose, and pullulan were degraded at less than $4 \%$ the rate of $B-C D$ cleavage. 
The purified cyclodextrinase from $B$. macerans had a $\mathrm{pH}$ and temperature optimum of $6.2-6.4$ and $30-40^{\circ} \mathrm{C}$, respectively $[15,16]$. The enzyme cleaved $\alpha$-, $B$-, and $\gamma \mathrm{CDs}$, maltoheptaose, maltohexaose, maltoheptaose, maltotetraose, and maltotriose to mainly maltose. Amylose, amylopectin, glycogen, or starch were negligibly degraded. For $\mathrm{CDs}$, the enzyme initially opened the ring to give a linear molecule with the corresponding number of glucose units. Linear maltooligosaccharides were then degraded by removal of maltose units from the nonreducing end.

A pullulan hydrolase from B. stearothermophilus KP1064 rapidly cleaved $\alpha$ and $B-C D, \alpha$-limit dextrins, amylose, and the maltotriose analogue, p-phenyl- $\alpha-D-$ maltoside [92]. Amylopectin, starch, and B-limit dextrins were hydrolyzed significantly slower. Maltose was the main product from these substrates, while pullulan was slowly cleaved to mainly panose. The ability to split $C D$ rings and cleave pullulan indicated that hydrolytic action could be of the endo type. The enzyme had a native molecular weight of 115,000 and consisted of two identical subunits. The enzyme had an isoelectric point of $4.4, \mathrm{pH}$ optimum of 5.8 , temperature optimum of $55^{\circ} \mathrm{C}$, and was thermostable at $65^{\circ} \mathrm{C}$ for ten minutes. Sulfhydryl reagents (p-chloromercuribenzoate, 5,5'-dithio-bis(2-nitrobenzoate) strongly inhibited activity, which indicated that cysteine was required for catalysis. 
The authors suggested assignment of the pullulan hydrolase to a unique type of maltogenic $\alpha$-amylase.

The intracellular cyclomaltodextrinase was purified from an alkalophilic Bacillus species that was identified as closely relating B. circulans [110]. The enzyme had an isoelectric point of 4.2 , a native molecular weight of 126,000 , and consisted of two subunits of 67,000 . The $\mathrm{pH}$ and temperature optima were 6.0 and $50^{\circ} \mathrm{C}$, respectively, but heating at $60^{\circ} \mathrm{C}$ for $10 \mathrm{~min}$ led to inactivation. The enzyme rapidly hydrolyzed $\alpha-C D$, maltotriose, and maltotetraose, while $B$ - and $\gamma-C D$, maltopentaose, maltohexaose, and maltoheptaose were cleaved 2-3 times slower. For all substrates, maltose was the main product. Maltose and starch were not degraded. Thiol reagents inhibited the enzyme, which suggested that sulfhydryl groups may exist in the active site.

The purified maltogenic $\alpha$-amylase from Bacillus thermoamyloliquefaciens KP 1071 had a native and subunit molecular weight of 115,000 and 67,000 , respectively [94]. The pl, pH optimum, and temperature optimum were $4.7,6.2$, and $63^{\circ} \mathrm{C}$, respectively. Maltogenic $\alpha$-amylase was thermostable for 10 minutes at $65^{\circ} \mathrm{C}$, $\mathrm{pH} 6.8$, in the presence of $5 \mathrm{mM}$ EDTA. However, a decrease in thermostability resulted when EDTA was absent or calcium was present. The enzyme rapidly hydrolyzed $\alpha$ - and $\beta-C D$, maltotriose, maltotetraose, maltopentaose, p-phenyl- $\alpha$ maltoside, $\alpha$-limit dextrin, and short chained amylose, while amylopectin, starch, and glycogen were slowly degraded. Maltose was the major product for all substrates, 
except maltotriose. Amylopectin was degraded in exo-fashion by preferential cleavage of maltose units from the nonreducing ends, and hydrolysis of it's $\alpha$-1,6branch points. While the enzyme slowly cleaved pullulan at the $\alpha$-1,4-bonds to give mainly panose, small amounts of glucose and maltose indicated the $\alpha-1,6$-bonds were cleaved at a lower frequency. Although activity was completely inhibited by p-chloromercuribenzoate, the enzyme did not contain a cysteine or a cystine residue. Comparison of amino acid compositions indicated the maltogenic $\alpha$-amylase to be homologous to the B. stearothermophilus KP 1064 maltogenic $\alpha$-amylase [92]. The authors suggest the $B$. thermoamyloliquefaciens to be the first maltogenic exo-acting $\alpha$-amylase able to cleave $\alpha$-1,6-bonds in amylopectin.

The thermostable cyclodextrinase from Clostridium thermohydrosulfuricum 39E [73] is the first and, thus far, only CDase to be isolated from a thermophilic anaerobe. The enzyme had optimal activity at $\mathrm{pH} 6.0$ and $65^{\circ} \mathrm{C}$, and had a halflife of three hours at $65^{\circ} \mathrm{C} . \alpha-\mathrm{CD}$ was rapidly hydrolyzed, while $B-C D$, starch, and amylose were degraded at rates $67 \%, 50 \%$, and $53 \%$, respectively, to that of $\alpha$-CD. p-Chloromercuribenzoate inhibited activity, which suggested sulfhydryl groups are involved in activity.

An intracellular amylase from Pseudomonas MSI had a molecular weight of 96,000, and optimal activity at $\mathrm{pH} 5.5$ and $50^{\circ} \mathrm{C}$ [29]. The enzyme rapidly hydrolyzed $\alpha-, \beta-$, and $\gamma-\mathrm{CD}$, linear maltodextrins, and amylose, while amylopectin, B-limit dextrin, and glycogen were hydrolyzed approximately 20 times slower. The 
amylase had endo-type activity in which equimolar amounts of glucose and maltose were produced as final products for all substrates.

A CD-degrading, cell-bound glucoamylase was isolated from a Flavobacterium species [6]. $\alpha-, \beta-$, and $\gamma-C D$, maltotriose, and amylose were rapidly degraded, with the final product exclusively glucose. Amylopectin and glycogen were poor substrates. The enzyme had a $\mathrm{pH}$ optimum of 5.5-6.5, required calcium for activity, and was inactive at $55^{\circ} \mathrm{C}$. The enzyme resembled human intestinal glucoamylase. Although there is a limited amount of published research on microbial cyclomaltodextrinases, the characterization of the CDases from the various Bacillus species indicates several common features shared among the enzymes: (a) They are dimers that have identical subunits. (b) They rapidly cleave CDs and linear malto-oligosaccharides at varying rates, while starch polymers are degraded much slower. (c) They produce mainly maltose with small quantities of glucose as the final degradation products, by apparent exo-cleavage of maltose units from the nonreducing ends. (d) In most cases, thiol reagents inhibit activity. Due to the high relatedness among Bacillus species, it is very probable that other species of bacilli also produce their own forms of CDase. To this date, there are no reports of purifications and characterizations of a CDase from either B. subtilis or B. caldolyticus. Consequently, the information presented in the following chapters should be considered new and unique with respect to bacterial CDases. 


\section{CHAPTER 3 \\ PURIFICATION, CHARACTERIZATION, AND COMPARISON OF THE CYCLOMALTODEXTRINASE FROM B. SUBTILIS 25S, B. CALDOLYTICUS C2, AND B. SUBTILIS HIGH TEMPERATURE GROWTH TRANSFORMANT H-17}

Enzymology is currently experiencing unprecedented growth and expansion in the development of thermostable industrial enzymes, particularly amylolytic enzymes for commercial starch processing [100]. Comparisons between thermolabile and thermostable enzymes may help to elucidate the molecular basis of enzyme thermostability, thus facilitating future protein engineering. The ideal enzymes for comparison should be derived from the same genus, and have similar physical, chemical, and structural properties but differ only in thermostability.

B. subtilis high temperature growth (HTG) transformants were previously generated by transformation of mesophilic, amylolytic $B$. subtilis $25 \mathrm{~S}$ with DNA from the obligate thermophile $B$. caldolyticus $C 2$ [39]. This chapter describes the purification, characterization, and comparison of a p-nitrophenyl- $\alpha$-D-maltosidehydrolyzing cyclomaltodextrinase (CDase) from B. subtilis 25S, B. caldolyticus C2, and B. subtilis $\mathrm{HTG}$ transformant $\mathrm{H}-17$. 
Materials and Methods

\section{Organisms and Growth Conditions}

The methodology for generation of $B$. subtilis $25 \mathrm{~S}, \mathrm{~B}$. caldolyticus $\mathrm{C} 2$, and B. subtilis $\mathrm{H}-17$ has been described previously $[38,39]$. All strains were grown aerobically, to late log phase, in $4 \mathrm{~L}$ batches $(250 \mathrm{rpm}$, airflow $0.5 \mathrm{~L} / \mathrm{min})$ at $37^{\circ} \mathrm{C}$ (25S) and $60^{\circ} \mathrm{C}(\mathrm{C} 2, \mathrm{H}-17)$ in a Queue Systems Mouse Fermenter (Parkersburg, WV). The growth medium consisted of $0.5 \%$ maltose (autoclaved separately), $0.5 \%$ starch, $2.5 \%$ Bacto peptone, 0.3\% Bacto yeast extract, $0.2 \%$ Bacto meat extract, $0.3 \%$ dipotassium hydrogen phosphate, and $0.1 \%$ potassium dihydrogen phosphate, $\mathrm{pH} 7.2$.

\section{Enzyme Purification}

Four liters of $25 \mathrm{~S}, \mathrm{C} 2$, or $\mathrm{H}-17$ cells were harvested by centrifugation at $9,000 \times \mathrm{g}$ in a Sorvall $\mathrm{RC}-5 \mathrm{~B}$ GSA rotor, at $4^{\circ} \mathrm{C}$ for $20 \mathrm{~min}$. The pellet was suspended in $20 \mathrm{mM}$, pH 8.0 potassium phosphate buffer, and lysozyme was added to a final concentration of $100 \mu \mathrm{g} / \mathrm{ml}$. The suspension was stirred at $37^{\circ} \mathrm{C}$ for $3 \mathrm{~h}$, after which the cell debris was removed by centrifugation at $27,000 \mathrm{x} g$ in a Sorvall RC-5B SS-34 rotor, at $4^{\circ} \mathrm{C}$ for $15 \mathrm{~min}$. Nucleic acids were precipitated by slow addition of a neutralized $10 \%(\mathrm{wt} / \mathrm{vol})$ solution of streptomycin sulfate (1/10 volume of the supernatant) [74], and after $1 \mathrm{~h}$ of stirring at $4^{\circ} \mathrm{C}$, the suspension was 
centrifuged at $27,000 \mathrm{x}$ g at $4^{\circ} \mathrm{C}$ for $15 \mathrm{~min}$. Solid ammonium sulfate was added to the supernatant and the $40-80 \%$ fraction was retained, and redissolved in $20 \mathrm{mM}, \mathrm{pH} 7.0$ potassium phosphate buffer containing $0.05 \%$ 2-mercaptoethanol (2-Me) (buffer A). Phenylmethylsulfonyl fluoride was added to a final concentration of $2 \mathrm{mM}$, and the solution was dialyzed for $24 \mathrm{~h}$ against $4 \times 2 \mathrm{~L}$ volumes of buffer A. Precipitated protein was removed from the dialysate by centrifugation at $27,000 \times \mathrm{g}$ at $4^{\circ} \mathrm{C}$ for $15 \mathrm{~min}$. The dialysate was applied to a $2.5 \times 35 \mathrm{~cm}$ DEAE-cellulose (Pharmacia, Uppsala, Sweden) column previously equilibrated with buffer $\mathrm{A}$, after which the column was washed with $500 \mathrm{ml}$ of buffer $\mathrm{A}$ at $30 \mathrm{ml} / \mathrm{h}\left(25^{\circ} \mathrm{C}\right)$ to remove unretained protein. The enzyme was then eluted at $15 \mathrm{ml} / \mathrm{h}$ with a $1 \mathrm{~L}$ linear $0-0.25 \mathrm{M}, \mathrm{pH} 7.0 \mathrm{NaCl}$ gradient, in buffer $\mathrm{A}$. Peak active fractions were pooled, concentrated (to approximately $10 \mathrm{ml}$ ) by ultrafiltration with a YM30 Amicon membrane, and applied to a $2.75 \times 75 \mathrm{~cm}$ Sephadex G-75 (Pharmacia) column previously equilibrated with buffer A. The enzyme was eluted at a rate of $10 \mathrm{ml} / \mathrm{h}\left(25^{\circ} \mathrm{C}\right)$ with buffer A. Peak active fractions were pooled, concentrated (to approximately $6 \mathrm{ml}$ ) by ultrafiltration with a YM30 membrane, and then equilibrated with $5 \mathrm{mM}, \mathrm{pH} 7.0$ phosphate buffer containing $0.05 \%$ (2-Me) (buffer B) by three ultra-filtrations with the same YM30 membrane. The retentate was applied to a $2.5 \times 20 \mathrm{~cm}$ hydroxyapatite (HA-Ultrogel) column previously equilibrated with buffer B. The column was then washed with $200 \mathrm{ml}$ of buffer $\mathrm{B}$ at $16 \mathrm{ml} / \mathrm{h}\left(25^{\circ} \mathrm{C}\right)$ to remove unretained protein. The enzyme eluted 
immediately behind the void volume which eliminated the need for a phosphate gradient. Peak active fractions were pooled, concentrated (to approximately $6 \mathrm{ml}$ ) by ultrafiltration with a YM30 membrane, and applied to a $2.75 \times 50 \mathrm{~cm}$ Sephacryl S-200 (Pharmacia) column previously equilibrated with buffer A. The enzyme was eluted at a rate of $12 \mathrm{ml} / \mathrm{h}\left(25^{\circ} \mathrm{C}\right)$ with buffer $\mathrm{A}$, and peak active fractions were pooled and concentrated (to approximately $2 \mathrm{ml}$ ) by ultrafiltration with an Amicon Centriprep-30. The enzyme sample was sterile-filtered, and stored aseptically with $0.05 \% 2-\mathrm{Me}$ or $0.01 \mathrm{mM}$ EDTA.

\section{Enzyme Assay}

Cyclomaltodextrinase (CDase) activity was determined by the release of p-nitrophenol from p-nitrophenyl- $\alpha$-D-maltoside (PNM) using a Beckman DU-7 spectrophotometer with an electrically-heated (pelltier) temperature control $\left(0-99^{\circ} \mathrm{C}+/-0.02^{\circ} \mathrm{C}\right)$. The standard reaction mixture $(1.0 \mathrm{ml})$ contained $33.3 \mathrm{mM}$, potassium phosphate buffer, $1.98 \mu \mathrm{mol} \mathrm{PNM}$, and $0-0.1 \mathrm{ml}$ of enzyme preparation. $25 \mathrm{~S}$ and $\mathrm{H}-17 \mathrm{CDase}$ were assayed at $\mathrm{pH} 7.5$ in the presence of $0.02 \% 2-\mathrm{Me}$, while $\mathrm{C} 2 \mathrm{CDase}$ was assayed at $\mathrm{pH} 7.0$ in the presence of $0.01 \mathrm{mM}$ EDTA. The reaction mixture was incubated at $35^{\circ} \mathrm{C}, 60^{\circ} \mathrm{C}$, or $65^{\circ} \mathrm{C}$ for the $25 \mathrm{~S}, \mathrm{C} 2$, or $\mathrm{H}-17$ enzyme, respectively. The complete mixture $(0.9 \mathrm{ml})$ without substrate was allowed to thermally equilibrate for $1 \mathrm{~min}$ after which $0.1 \mathrm{ml}$ of warmed substrate was added. The increase in absorbance/min at $400 \mathrm{~nm}$ was automatically calculated at $25 \mathrm{sec}$ 
intervals for approximately 5 min. A molar extinction coefficient of 9,600 $\mathrm{M}^{-1} \mathrm{~cm}^{-1}$ was used to calculate the amount of $\mathrm{p}$-nitrophenol released/min [93]. One unit of enzyme activity was defined as the amount of enzyme required for the release of $1 \mu \mathrm{mol}$ of $\mathrm{p}$-nitrophenol/ $\mathrm{ml} / \mathrm{min}$. Protein was estimated by the method of Lowry et al. [45], with bovine serum albumin as the standard.

To perform activity stains on polyacrylamide and isoelectric focusing gels, the gel was soaked in $2 \times 200 \mathrm{ml}$ volumes of $100 \mathrm{mM}$, pH 7.5 potassium phosphate buffer for $10 \mathrm{~min}$, and then incubated at $35^{\circ} \mathrm{C}$ or $60^{\circ} \mathrm{C}$ for $10-20 \mathrm{~min}$ in $33 \mathrm{mM}, \mathrm{pH}$ 7.5 potassium phosphate buffer containing $3 \mathrm{mg} / \mathrm{ml} \mathrm{PNM}$ and $0.02 \%$ 2-Me. Bands that displayed enzymatic activity stained yellow, while the gel remained clear. The gel was then rinsed in deionized water and stained for protein with Coomassie Brilliant Blue R-250 and Amidoschwartz 10B.

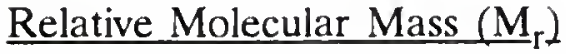

The $\mathrm{M}_{\mathrm{r}}$ of the enzymes was determined by polyacrylamide gel electrophoresis (PAGE) with and without sodium dodecyl sulfate (SDS) and 2-Me, using Bio-Rad Mini-Protean II slab gels and the buffer system of Laemmli [35]. Spacing and separating gels were $4.0 \%$ and $7.5 \%$ polyacrylamide, respectively. Molecular weight standards (26,600-180,000) were obtained from Sigma Chemical Co., St. Louis, Mo. 
Gels were stained with $0.15 \%$ Coomassie Brilliant Blue R-250 and $0.05 \%$ Amidoschwartz 10B in. 40\% ethanol/10\% glacial acetic acid for $2 \mathrm{~h}$.

\section{$\underline{\text { Isoelectric Point (pl) }}$}

The $\mathrm{pI}$ values were determined according to manufacture's instructions, using Isogel Agarose IEF Plates (FMC BioProducts) over a pH range of 3-10. IEF standards (pI 3.55-9.9) were purchased from Sigma. Isoelectric focusing was performed with a Hoeffer Isobox cooling chamber at $12^{\circ} \mathrm{C}$. After staining for activity (see Enzyme Assay), the gel was then rinsed in deionized water and stained for protein with Coomassie Brilliant Blue R-250 as described by the manufacturer.

\section{Effect of Temperature and $\mathrm{pH}$}

Temperature profiles for the $25 \mathrm{~S}, \mathrm{C} 2$, and $\mathrm{H}-17$ enzymes were determined under standard conditions over the range $10-52^{\circ} \mathrm{C}(25 \mathrm{~S})$ and $25-80^{\circ} \mathrm{C}(\mathrm{C} 2, \mathrm{H}-17)$. The $\mathrm{pH}$ profiles were determined under standard assay conditions in $33 \mathrm{mM}$ phosphate, over the $\mathrm{pH}$ range $4-10$ for the $25 \mathrm{~S}, \mathrm{C} 2$, and $\mathrm{H}-17$ enzymes. Initial velocities within the first $1.5 \mathrm{~min}$ were used to calculate relative activities (\% of maximum). 


\section{Effect of Chemicals}

To determine the effect of various cations, all solutions used were prepared from triple-deionized water. The $25 \mathrm{~S}, \mathrm{C} 2$, or $\mathrm{H}-17$ enzyme was dialyzed against $2 \times 0.5 \mathrm{~L}$ volumes of $\mathrm{pH} 7.5,7.0$, or 7.5 , respectively, $50 \mathrm{mM}$ sodium barbital/ 10 $\mathrm{mM}$ EDTA $/ 0.05 \%$ 2-Me, for $8 \mathrm{~h}$ at $4^{\circ} \mathrm{C}$. The enzymes were then dialyzed against $3 \times 0.5 \mathrm{~L}$ volumes of the same buffer without EDTA, for $16 \mathrm{~h}$ at $4^{\circ} \mathrm{C}$. Activity was determined under standard conditions, except that the assay buffer was $50 \mathrm{mM}$ sodium barbital/0.02\% 2-Me, and contained a final concentration of $5 \mathrm{mM}$ cation (chloride form). The reaction mixture without substrate was pre-incubated with the selected cation for $10 \mathrm{~min}$ at $35^{\circ} \mathrm{C}(25 \mathrm{~S})$ or $45^{\circ} \mathrm{C}(\mathrm{C} 2, \mathrm{H}-17)$. Residual activity was then determined at standard incubation temperatures. The effect of 2-Me, EDTA or Tris- $\mathrm{HCl}$ on $25 \mathrm{~S}, \mathrm{C} 2$, and $\mathrm{H}-17$ activity was examined under standard assay conditions. The final concentration ranges were $0.005-0.5 \%(2-\mathrm{Me}), 0.005-1.0 \mathrm{mM}$ (EDTA) or $5 \mathrm{mM}$ (Tris $\mathrm{HCl})$.

\section{Thermal Stability}

The effect of 2-Me (0.005-0.5\%) or EDTA $(0.005-1.0 \mathrm{mM})$ on thermostability was examined. Under standard assay conditions, the enzyme was incubated in closed cuvettes for $1 \mathrm{~h}$, at a single temperature maintained by the spectrophotometer heating unit. Incubation temperatures ranged from $35-45^{\circ} \mathrm{C}$ (25S) and $60-75^{\circ} \mathrm{C}(\mathrm{C} 2, \mathrm{H}-17)$. Assays were performed at 5-15 min intervals during 
the incubation period, by the addition of PNM. Initial velocities were calculated and related to those at time zero.

$\underline{\mathrm{K}}_{\mathrm{m}}$ Value Determination

The initial rates of hydrolysis of PNM were performed under standard assay conditions. The $K_{m}$ values were determined by plotting $1 / \mathrm{V}$ vs $1 / \mathrm{S}$ according to the Lineweaver-Burk method [42].

\section{Amino Acid Analysis}

Amino acid analyses were performed by the Protein Chemistry Core Facility in the Department of Biochemistry, University of Florida. Protein samples were prepared by hydrolysis in $6 \mathrm{~N} \mathrm{HCl}$, or $\mathrm{DMSO} / \mathrm{HCl}$ hydrolysis for cysteic acid determination. Amino acid analyses were performed in duplicate on a Beckman 6300 instrument, using a cationic exchange resin and ninhydrin-based quantification. Standards were run before and after each analysis, and internal standards were included for every analysis. 


\section{$\underline{\text { Results and Discussion }}$}

The purifications of the 25S, C2, and H-17 CDase are summarized in Tables $1-3$, respectively. Initial studies indicated that the $25 \mathrm{~S}$ enzyme required a minimum of $0.02 \% 2-\mathrm{Me}$ in order to maintain activity, while the $\mathrm{C} 2$ or $\mathrm{H}-17$ enzyme required a minimum of $0.02 \%$ 2-Me or $0.01 \mathrm{mM}$ EDTA for thermostability. Therefore, $0.05 \%$ 2-Me was included in all column chromatography buffers.

All three enzymes migrated as single bands during SDS-PAGE (Figures 1-3). The $M_{r}$ of the 25S, C2, and H-17 CDase was approximately 55,000, 60,000, and 55,000 as determined by SDS-PAGE, and, 110,000, 120,000, and 110,000 as determined by PAGE, respectively. This indicates that the native structure of all three enzymes is a dimer composed of two subunits of equivalent $M_{r}$. Table 4 summarizes the biochemical and biophysical characterization of the 25S, C2, and H-17 CDase. All three enzymes had the same pI (Figure 4), and similar pH optima (Figure 5), $\mathrm{K}_{\mathrm{m}}$ values for $\mathrm{PNM}$, and Tris- $\mathrm{HCl}$ inhibition. Neither enzyme had a cation requirement for activity or thermostability, while each enzyme exhibited similar cation inhibition (Table 5). However, the 25S, C2, and H-17 CDase exhibited strikingly different thermostabilities. The purified $25 \mathrm{~S}$ enzyme showed optimal activity between $35-37^{\circ} \mathrm{C}$ (Figure 6), and complete inactivation after incubation at $45^{\circ} \mathrm{C}$ for $10 \mathrm{~min}$, when assayed at $\mathrm{pH} 7.5$ (Figure 7). Although $0.02 \%$ 
Table 1. Purification of B. subtilis $25 \mathrm{~S}$ cyclomaltodextrinase.

\section{Enzyme Activity}

\begin{tabular}{lccccc}
\cline { 2 - 5 } $\begin{array}{l}\text { Purification } \\
\text { Step }\end{array}$ & $\begin{array}{r}\text { Total } \\
\text { Protein } \\
(\mathrm{mg})\end{array}$ & $\begin{array}{c}\text { Total } \\
\text { Activity } \\
\text { (Units) }\end{array}$ & $\begin{array}{c}\text { Specific } \\
\text { Activity } \\
(\mathrm{U} / \mathrm{mg} \text { Prot. })\end{array}$ & $\begin{array}{c}\text { Purification } \\
\text { (Fold) }\end{array}$ & $\begin{array}{c}\text { Yield } \\
(\%)\end{array}$ \\
$\begin{array}{l}\text { Cell-free extract } \\
650\end{array}$ & 42.0 & 0.065 & 1.0 & 100 \\
$\begin{array}{l}40-80 \%\left(\mathrm{NH}_{4}\right)_{2} \mathrm{SO}_{4} \\
\text { fraction }\end{array}$ & 217 & 28.6 & 0.12 & 1.8 & 64 \\
$\begin{array}{l}\text { DEAE-cellulose } \\
\text { chromatography }\end{array}$ & 28.5 & 9.8 & 0.34 & 5.2 & 23 \\
$\begin{array}{l}\text { Sephadex G-75 } \\
\text { chromatography }\end{array}$ & 15.4 & 6.7 & 0.44 & 6.8 & 16 \\
$\begin{array}{l}\text { Hydroxyapatite } \\
\text { chromatography }\end{array}$ & 2.5 & 6.3 & 2.52 & 38.8 & 15 \\
$\begin{array}{l}\text { Sephacryl S-200 } \\
\text { chromatography }\end{array}$ & 0.5 & 4.9 & 10.0 & 154 & 12
\end{tabular}


Table 2. Purification of $B$. caldolyticus $\mathrm{C} 2$ cyclomaltodextrinase.

Enzyme Activity

\begin{tabular}{lccccc}
\cline { 2 - 5 } $\begin{array}{l}\text { Purification } \\
\text { Step }\end{array}$ & $\begin{array}{r}\text { Total } \\
\text { Protein } \\
(\mathrm{mg})\end{array}$ & $\begin{array}{c}\text { Total } \\
\text { Activity } \\
\text { (Units) }\end{array}$ & $\begin{array}{c}\text { Specific } \\
\text { Activity } \\
\text { (U/mg Prot.) }\end{array}$ & $\begin{array}{c}\text { Purification } \\
\text { (Fold) }\end{array}$ & $\begin{array}{c}\text { Yield } \\
(\%)\end{array}$ \\
$\begin{array}{lcccc}\text { Cell-free extract } \\
550\end{array}$ & 28.0 & 0.051 & 1.0 & 100 \\
$\begin{array}{l}40-80 \%\left(\mathrm{NH}_{4}\right)_{2} \mathrm{SO}_{4} \\
\text { fraction }\end{array}$ & 160 & 15.0 & 0.09 & 1.8 & 54 \\
$\begin{array}{l}\text { DEAE-cellulose } \\
\text { chromatography }\end{array}$ & 22.1 & 8.2 & 0.37 & 7.4 & 29 \\
$\begin{array}{l}\text { Sephadex G-75 } \\
\text { chromatography }\end{array}$ & 11.4 & 8.0 & 0.70 & 14.0 & 29 \\
$\begin{array}{l}\text { Hydroxyapatite } \\
\text { chromatography }\end{array}$ & 2.0 & 7.3 & 3.7 & 74.0 & 26 \\
$\begin{array}{l}\text { Sephacryl S-200 } \\
\text { chromatography }\end{array}$ & 0.9 & 5.3 & 6.0 & 120 & 19
\end{tabular}


Table 3. Purification of B. subtilis $\mathrm{H}-17$ cyclomaltodextrinase.

Enzyme Activity

\begin{tabular}{lccccc}
\cline { 2 - 5 } $\begin{array}{l}\text { Purification } \\
\text { Step }\end{array}$ & $\begin{array}{c}\text { Total } \\
\text { Protein } \\
(\mathrm{mg})\end{array}$ & $\begin{array}{c}\text { Total } \\
\text { Activity } \\
\text { (Units) }\end{array}$ & $\begin{array}{c}\text { Specific } \\
\text { Activity } \\
\text { (U/mg Prot.) }\end{array}$ & $\begin{array}{c}\text { Purification } \\
\text { (Fold) }\end{array}$ & $\begin{array}{c}\text { Yield } \\
(\%)\end{array}$ \\
$\begin{array}{l}\text { Cell-free extract } \\
\text { (Un }\end{array}$ & 520 & 31.7 & 0.061 & 1.0 & 100 \\
$\begin{array}{l}40-80 \%\left(\mathrm{NH}_{4}\right)_{2} \mathrm{SO}_{4} \\
\text { fraction }\end{array}$ & 136 & 15.6 & 0.11 & 1.8 & 49 \\
$\begin{array}{l}\text { DEAE-cellulose } \\
\text { chromatography }\end{array}$ & 34.0 & 9.2 & 0.27 & 4.4 & 29 \\
$\begin{array}{l}\text { Sephadex G-75 } \\
\text { chromatography }\end{array}$ & 14.4 & 7.7 & 0.53 & 8.7 & 24 \\
$\begin{array}{l}\text { Hydroxyapatite } \\
\text { chromatography }\end{array}$ & 3.3 & 6.6 & 1.8 & 29.5 & 19 \\
$\begin{array}{l}\text { Sephacryl S-200 } \\
\text { chromatography }\end{array}$ & 0.9 & 5.7 & 6.3 & 103 & 18
\end{tabular}




\section{$180 \mathrm{~K}$}

$116 \mathrm{~K}$

$84 \mathrm{~K}$

$58 \mathrm{~K}$

\section{$48.5 \mathrm{~K}$}

\section{5}

Figure 1. SDS-PAGE of purified B. subtilis $25 \mathrm{~S}$ cyclomaltodextrinase on a $7.5 \%$ polyacrylamide gel. Lane 1: SDS molecular weight standards (1) $\alpha_{2}$-macroglobulin; (2) B-galactosidase; (3) fructose-6-phosphate kinase; (4) pyruvate kinase; (5) fumarase; (6) lactate dehydrogenase. Lane 2: $10-20 \mu \mathrm{g}$ of purified enzyme. 
$180 \mathrm{~K}$

$116 K$

$84 K$

$58 \mathrm{~K}$

$48.5 \mathrm{~K}$

Figure 2. SDS-PAGE of purified B. caldolyticus C2 cyclomaltodextrinase on a 7.5\% polyacrylamide gel. Lane 1: SDS molecular weight standards (1) $\alpha_{2}$-macroglobulin; (2) B-galactosidase; (3) fructose-6-phosphate kinase; (4) pyruvate kinase; (5) fumarase. Lane 2: 10-20 $\mathrm{gg}$ of purified enzyme. 


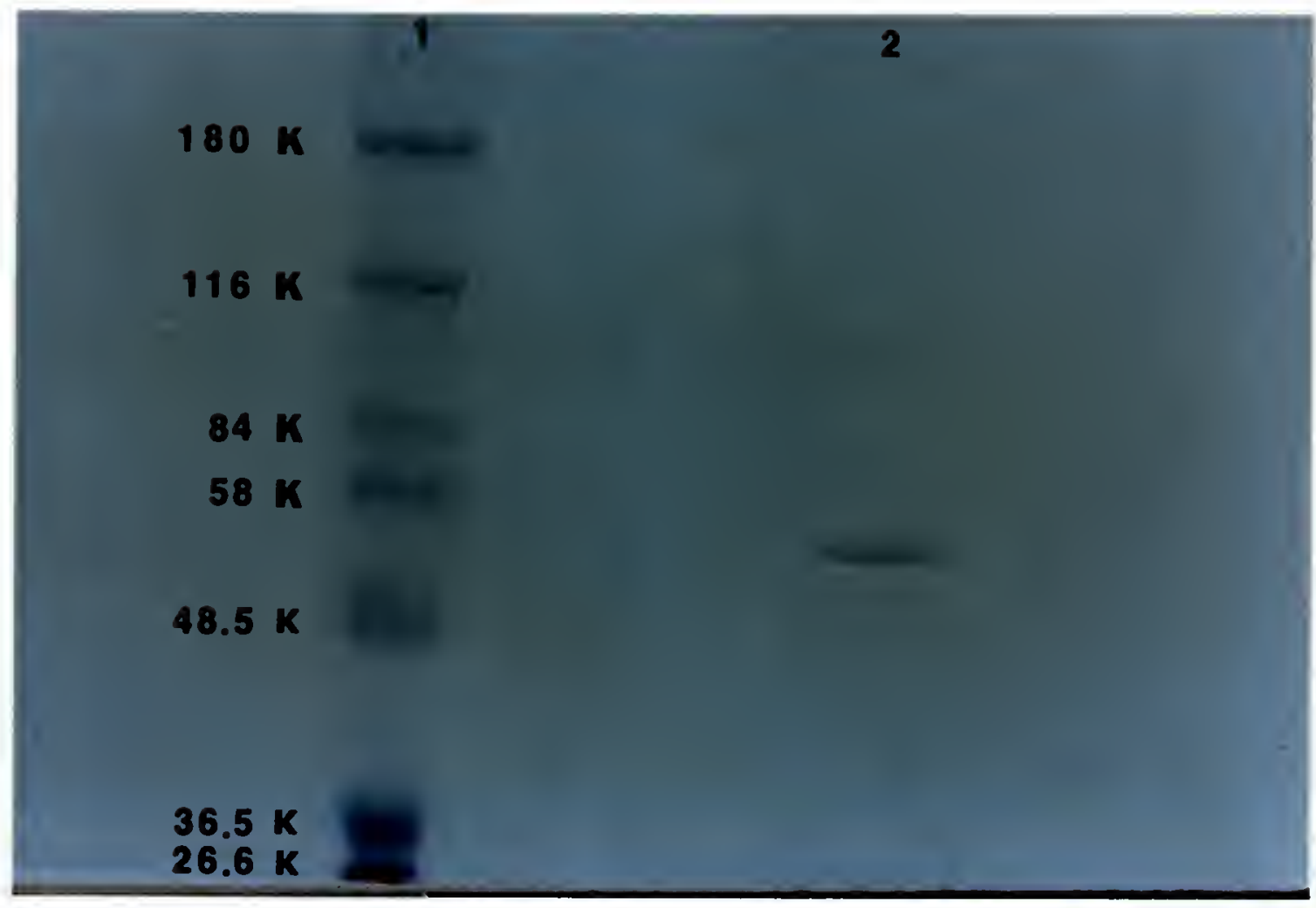

Figure 3. SDS-PAGE of purified B. subtilis $\mathrm{H}-17$ cyclomaltodextrinase on a $7.5 \%$ polyacrylamide gel. Lane 1: SDS molecular weight standards (1) $\alpha_{2}$ macroglobulin; (2) B-galactosidase; (3) fructose-6-phosphate kinase; (4) pyruvate kinase; (5) fumarase; (6) lactate dehydrogenase; (7) triosephosphate isomerase. Lane $2: 10-20 \mu \mathrm{g}$ of purified enzyme. 
Table 4. Biochemical and biophysical comparison of B. subtilis 25S, B. caldolyticus $\mathrm{C} 2$, and $B$. subtilis $\mathrm{H}-17$ cyclomaltodextrinase.

$\begin{array}{lccc} & \underline{\mathrm{H}-17} & \underline{25 \mathrm{~S}} & \underline{\mathrm{C} 2} \\ \text { Temperature Optimum } & 65-68^{\circ} \mathrm{C} & 35^{\circ} \mathrm{C} & 60^{\circ} \mathrm{C} \\ \text { \% Activity Remaining After } 1 \text { hr at } 65^{\circ} \mathrm{C} & 100 & 0 & 66 \\ \text { pH Optimum } & 7.5 & 7.5 & 7.0 \\ \text { Isoelectric Point } & 4.8 & 4.8 & 4.8 \\ \mathrm{~K}_{\mathrm{m}} \text { for PNM (mM) } & 1.46 & 2.96 & 1.31 \\ \text { Relative Molecular Mass (M }) \text { (SDS-PAGE) } & 55,000 & 55,000 & 60,000 \\ 0.02 \% \text { 2-Mercaptoethanol Requirement } & + & + & + \\ 0.005 \text { mM EDTA Requirement } & + & - & + \\ \text { Inhibition by } 5 \text { mM Tris } & + & + & +\end{array}$




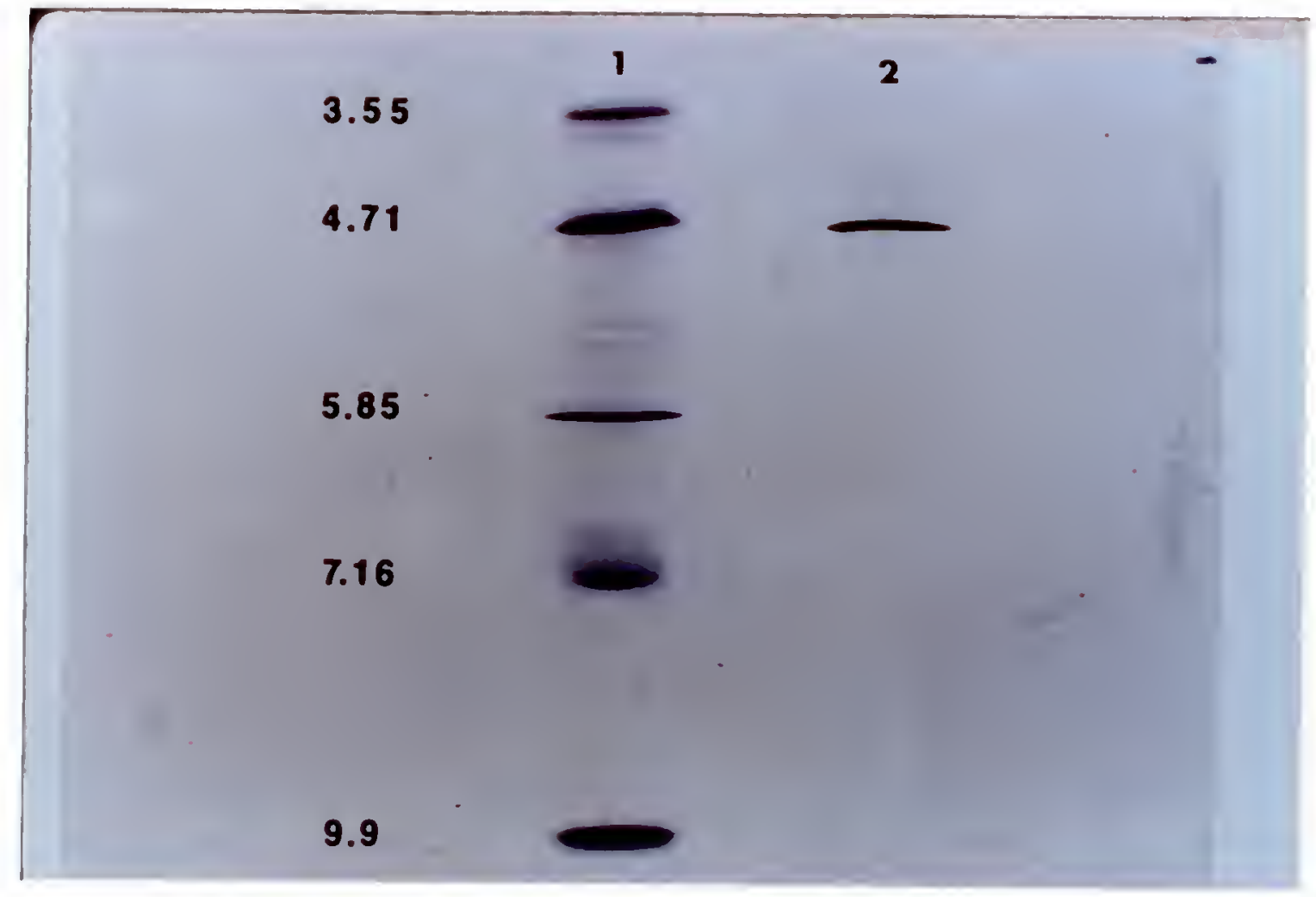

Figure 4. Isoelectric focusing gel of purified B. subtilis $25 \mathrm{~S}, B$. caldolyticus $\mathrm{C} 2$, or $B$. subtilis H-17 cyclomaltodextrinase. Lane 1: pI standards (1) amyloglucosidase; (2) ovalbumin; (3) carbonic anhydrase; (4) horse myoglobin (major and minor); (5) cytochrome C. Lane 2: 10-20 $\mu \mathrm{g}$ purified enzyme. 
Figure 5. Effect of $\mathrm{pH}$ on the activity of (A) B. subtilis $25 \mathrm{~S}$ cyclomaltodextrinase, (B) B. caldolyticus $\mathrm{C} 2$ cyclomaltodextrinase, and (C) B. subtilis $\mathrm{H}-17$ cyclomaltodextrinase. The $\mathrm{pH}$ profiles were determined under standard assay conditions in $33 \mathrm{mM}$ phosphate, over the $\mathrm{pH}$ range 4-10 for each enzyme. Initial velocities within the first 1.5 min were used to calculate relative activities (\% of maximum). 

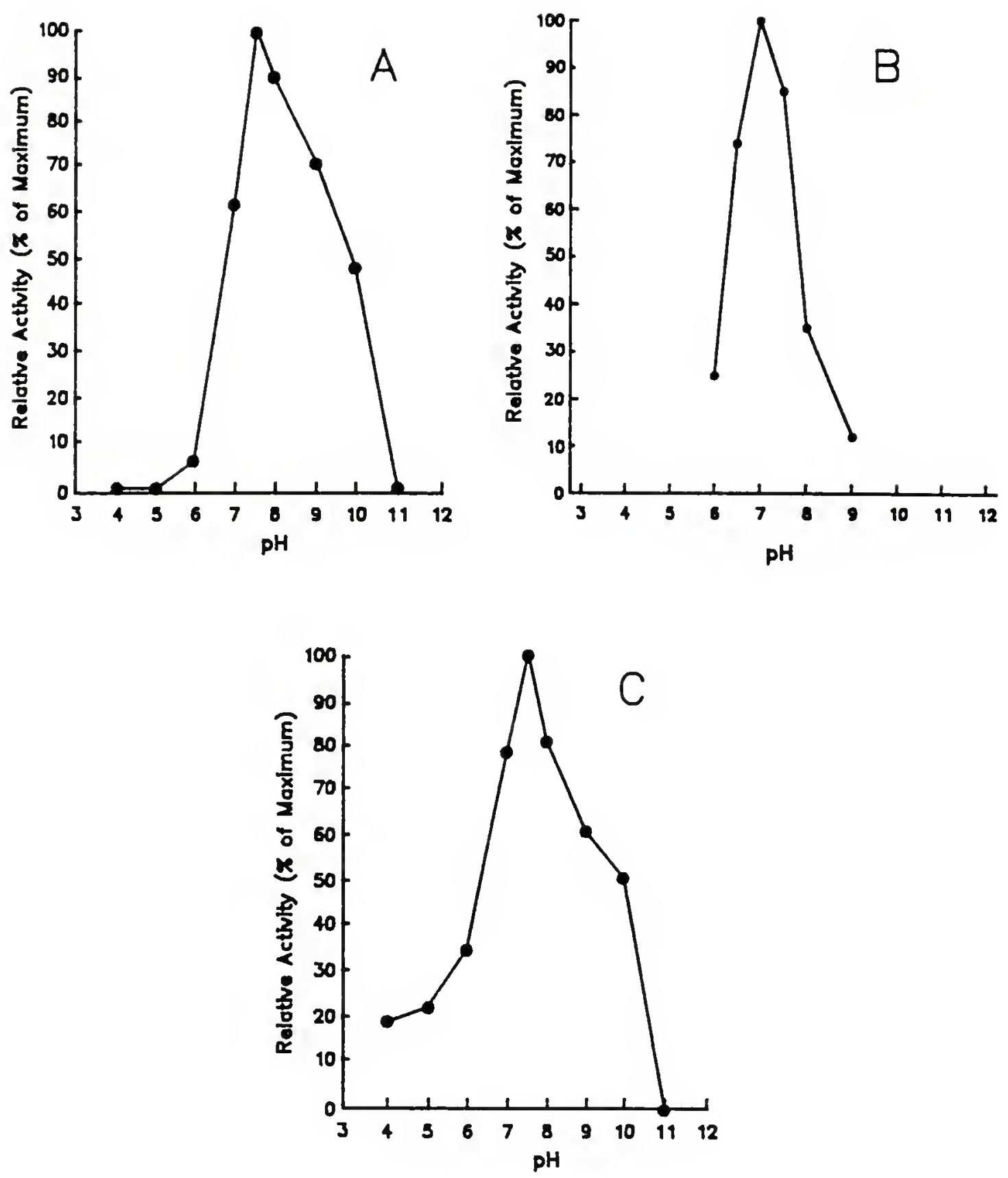
Table 5. Cationic inhibition of B. subtilis 25S, B. caldolyticus $\mathrm{C}$, and B. subtilis H-17 cyclomaltodextrinase.

$(5 \mathrm{mM}$ final conc.) \% Inhibition $25 \mathrm{~S} \%$ Inhibition $\mathrm{H}-17 \%$ Inhibition $\mathrm{C} 2$

$\begin{array}{lrrr}\mathrm{MgCl}_{2} & 69 & 42 & 41 \\ \mathrm{CaCl}_{2} & 90 & 72 & 66 \\ \mathrm{SrCl}_{2} & 78 & 38 & 47 \\ \mathrm{BaCl}_{2} & 87 & 50 & 40 \\ \mathrm{MnCl}_{2} & 100 & 100 & 100 \\ \mathrm{CoCl}_{2} & 100 & 100 & 100 \\ \mathrm{ZnCl} & 100 & 82 & 100 \\ & & & \\ \mathrm{LiCl} & 14 & 18 & 23 \\ \mathrm{NaCl} & 0 & 0 & 0 \\ \mathrm{KCl} & 0 & 0 & 0 \\ \mathrm{CsCl} & 0 & 0 & 0\end{array}$


Figure 6. Effect of temperature on the activity of (A) B. subtilis $25 \mathrm{~S}$ cyclomaltodextrinase, (B) B. caldolyticus $\mathrm{C} 2$ cyclomaltodextrinase, and (C) B. subtilis $\mathrm{H}-17$ cyclomaltodextrinase. Temperature profiles were determined under standard conditions over the range $10-52^{\circ} \mathrm{C}(25 \mathrm{~S})$ and $25-80^{\circ} \mathrm{C}(\mathrm{C} 2, \mathrm{H}-17)$. 

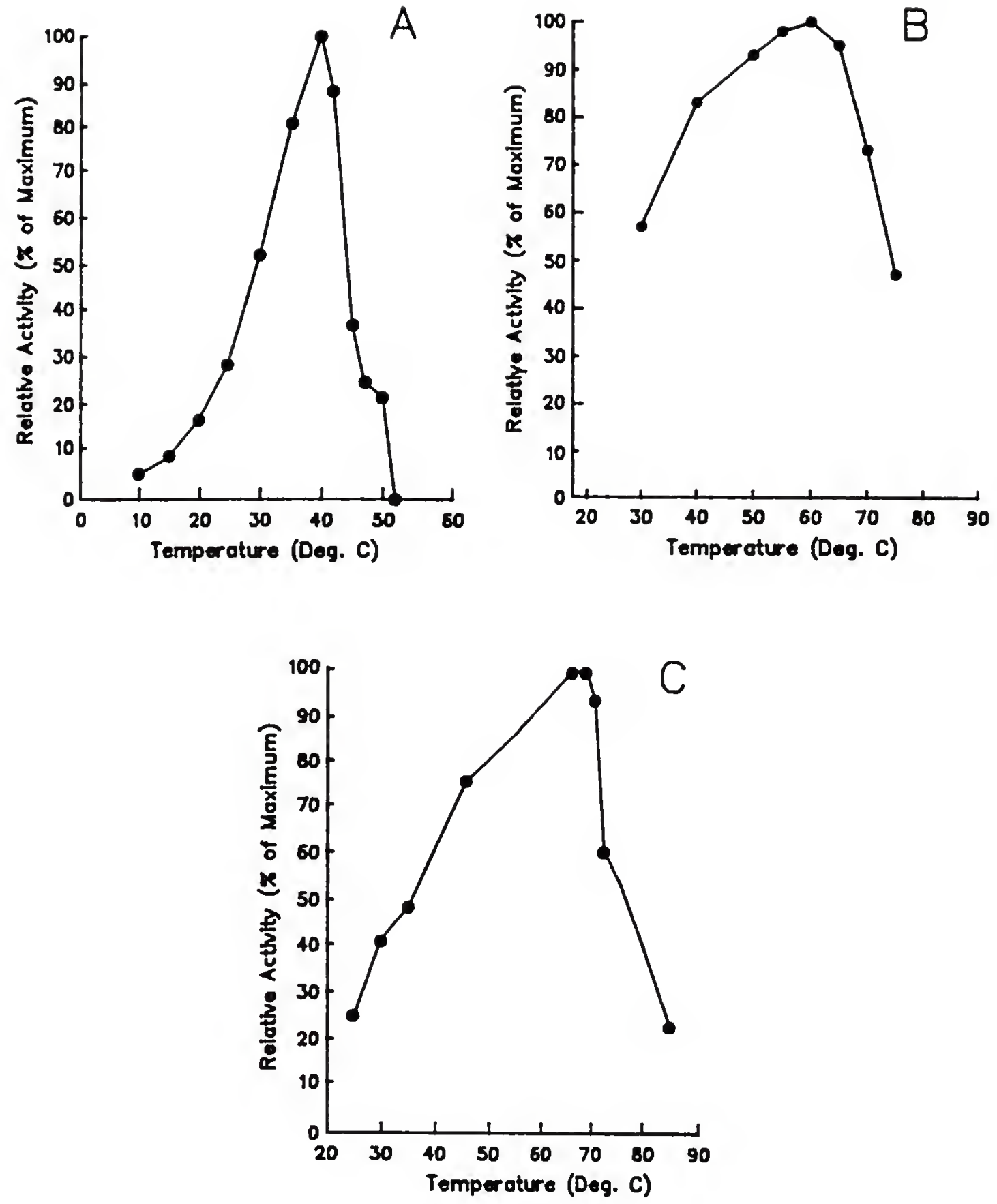
Figure 7. (A) Effect of temperature and incubation time on the thermostability of B. subtilis $25 \mathrm{~S}$ cyclomaltodextrinase. (B) Effect of temperature, incubation time, and $0.02 \% 2-\mathrm{Me}$ or $0.01 \mathrm{mM}$ EDTA on the thermostability of $B$. caldolyticus $\mathrm{C} 2$ cyclomaltodextrinase. (C) Effect of temperature, incubation time, and $0.02 \% \quad 2-\mathrm{Me}$ on the thermostability of the $B$. subtilis $\mathrm{H}-17$ cyclomaltodextrinase. (D) Effect of temperature, incubation time, and $0.005 \mathrm{mM}$ EDTA on the thermostability of $B$. subtilis $\mathrm{H}-17$ cyclomaltodextrinase. Under standard assay conditions, the enzyme was incubated in closed cuvettes for $1 \mathrm{~h}$, at a single temperature maintained by the spectrophotometer heating unit. Incubation temperatures ranged from $35-45^{\circ} \mathrm{C}(25 \mathrm{~S})$ and $60-75^{\circ} \mathrm{C}(\mathrm{C} 2, \mathrm{H}-17)$. Assays were performed at 5-15 min intervals during the incubation period, by the addition of PNM. Initial velocities within the first $0.5 \mathrm{~min}$ were calculated and related to those at time zero. 

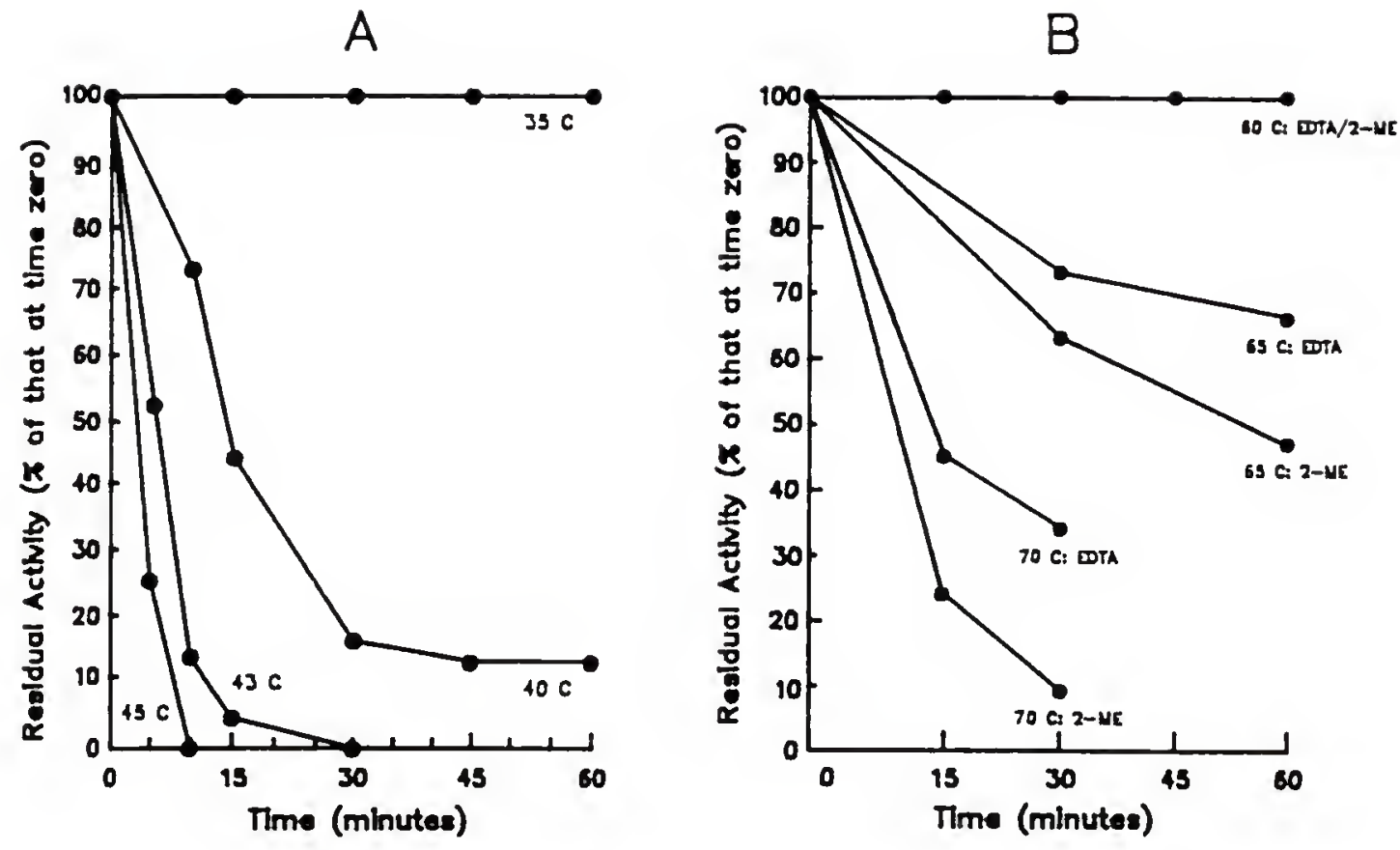

C
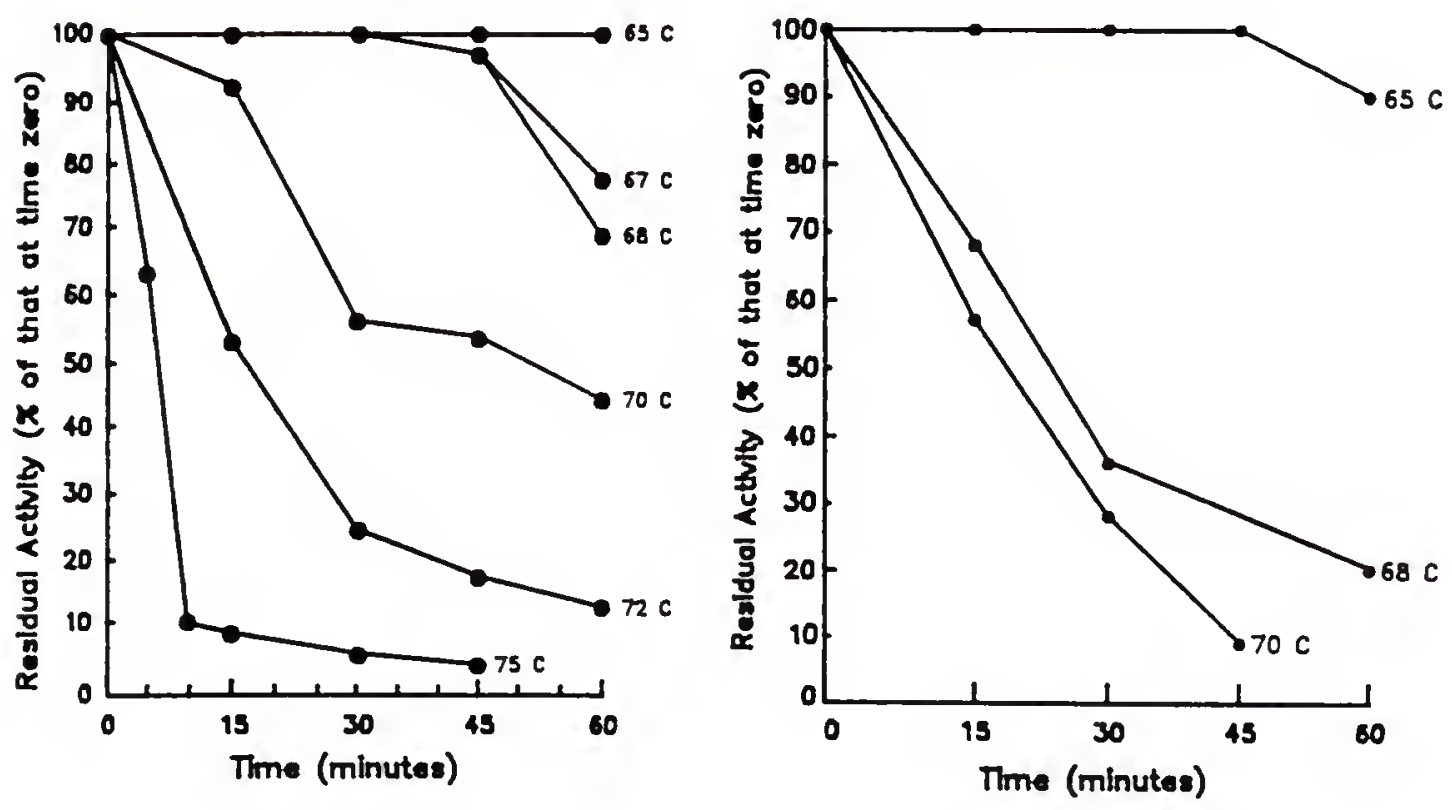
2-Me was required to maintain $25 \mathrm{~S}$ enzyme activity, neither 2-Me or EDTA, at all levels tested, enhanced the thermostability of $25 S$ enzyme.

This contrasts with the purified $\mathrm{C} 2$ enzyme which showed optimal activity at $60^{\circ} \mathrm{C}$ (Figure 6), and retained $100 \%$ of initial activity after incubation at $60^{\circ} \mathrm{C}$ for $2 \mathrm{~h}$ (Figure 7), when assayed at $\mathrm{pH}$ 7.0. However, a minimum concentration of $0.02 \%$ 2-Me or $0.01 \mathrm{mM}$ EDTA was required for thermostability of $\mathrm{C} 2 \mathrm{CD}$ ase, although EDTA more effectively stabilized the C2 enzyme, than did 2-Me. Furthermore, the $\mathrm{H}-17$ enzyme showed optimal activity between $65-68^{\circ} \mathrm{C}$ (Figure 6), and retained $100 \%$ of initial activity after incubation at $65^{\circ} \mathrm{C}$ for $1 \mathrm{~h}$ (Figure 7), when assayed at $\mathrm{pH} 7.5$. A minimum concentration of $0.02 \% 2-\mathrm{Me}$ or $0.005 \mathrm{mM}$ EDTA was required for thermostability of the H-17 enzyme. In contrast with the C2 enzyme, 2-Me more effectively stabilized the H-17 enzyme, than did EDTA. For both the $\mathrm{C} 2$ and $\mathrm{H}-17 \mathrm{CDase}$, higher levels of either compound did not enhance thermostability, and combinations of 2-Me and EDTA did not produce a synergistic effect whereby thermostability was increased.

The maintenance of $25 \mathrm{~S}$ enzyme activity by 2 -Me probably occurs by reduction of an oxidized sulfhydryl residue(s) (cysteine) at the active site, or by reduction of a disulfide bond that forms at the active site due to oxidation. However, the mechanism by which 2-Me confers $\mathrm{C} 2$ and $\mathrm{H}-17$ enzyme thermostability is unknown. The low level of 2 -Me may be sufficient to reduce oxidized sulfhydryl groups to allow them to undergo disulfide bond formation. 
Another, but less likely, mechanism could be 2-Me's intramolecular bifunctional hydrogen bonding with polar side groups. However, the use of an extrinsic factor such as 2-Me for stabilization may simply reflect the nature of the reducing atmosphere and presence of other sulfhydryl-containing molecules inside the cell which protect cysteine sulfhydryl groups. It is possible that EDTA confers $\mathrm{H}-17$ enzyme thermostability by either forming an ion pair bridge between its negatively charged carboxyl groups and positively charged amino side groups, or by chelating cations that interfere with intramolecular ion-pair formation between charged amino acid side groups.

Table 6 shows the amino acid compositions of the 25S, C2, and H-17 CDase. The most significant difference between the $25 \mathrm{~S}$ and $\mathrm{C} 2$ enzyme is the increase in the hydrophobic residues alanine, leucine, and proline. One of the most important mechanisms that confers enzyme thermostability is hydrophobic interaction $[3,50,99]$. Our results concur with a previous observation which reported a strong correlation between an increase in alanine, leucine and particularly proline, and the rise in thermostability of five Bacillus oligo-1,6-glucosidases [95]. Proline, due to its $\alpha$-helix breaking ability, can contribute to improved turn stabilization and a greater potential for close packing of protein domains. Thus, by increasing the number of proline residues in conjunction with other hydrophobic residues such as leucine and alanine, thermostability may be enhanced by strengthened hydrophobic interactions, thereby tightening the molecule as a whole. 
Table 6. Amino acid compositions of B. subtilis 25S, B. caldolyticus C2, and $B$. subtilis $\mathrm{H}-17$ cyclomaltodextrinase.

$\underline{25 \mathrm{~S}} \quad \underline{\mathrm{H}-17} \quad \underline{\mathrm{C} 2}$

Amino Acid Mol\% Res/Subunit Mol\% Res/Subunit Mol\% Res/Subunit

$\begin{array}{lrrrrrr}\text { Cys } & 1.51 & 8 & 1.60 & 8 & 2.05 & 11 \\ \text { Asx } & 11.94 & 60 & 7.30 & 37 & 9.36 & 51 \\ \text { Thr } & 3.82 & 19 & 3.27 & 16 & 5.00 & 27 \\ \text { Ser } & 4.20 & 21 & 4.33 & 22 & 4.72 & 26 \\ \text { Glx } & 10.16 & 51 & 9.66 & 48 & 11.05 & 60 \\ \text { Pro } & 3.79 & 19 & 4.53 & 23 & 4.86 & 27 \\ \text { Gly } & 18.31 & 92 & 22.65 & 113 & 9.63 & 53 \\ \text { Ala } & 6.58 & 33 & 8.75 & 44 & 12.02 & 66 \\ \text { Val } & 5.32 & 27 & 5.96 & 30 & 5.68 & 31 \\ \text { Met } & 0.22 & 1 & 0.23 & 1 & 0.15 & 1 \\ \text { Ile } & 4.68 & 23 & 4.15 & 21 & 4.75 & 26 \\ \text { Leu } & 7.13 & 36 & 7.59 & 38 & 9.73 & 53 \\ \text { Tyr } & 3.34 & 17 & 2.19 & 11 & 3.28 & 18 \\ \text { Phe } & 5.63 & 28 & 3.41 & 17 & 4.11 & 22 \\ \text { His } & 3.12 & 16 & 2.55 & 13 & 2.72 & 15 \\ \text { Lys } & 5.02 & 25 & 6.58 & 33 & 5.55 & 30 \\ \text { Arg } & 5.23 & 26 & 5.36 & 27 & 5.34 & 29\end{array}$


Similarly, the H-17 enzyme shows a significant decrease in (aspartate/asparagine), tyrosine and phenylalanine residues, accompanied by significant increases in glycine, alanine, proline and lysine residues, when compared to the thermolabile $25 \mathrm{~S}$ enzyme. The increase in alanine, glycine and proline may increase the H-17 enzyme's internal hydrophobicity, which in turn might influence the enzyme's thermostability. Interestingly, although there were changes in the amino acid composition between the two enzymes, there was no change in the pI value. For the $\mathrm{H}-17$ enzyme, the increase in lysine residues may be offset by the decrease in aspartate/asparagine, especially if the decrease was in asparagine residues.

The results indicate that protein thermostability may be achieved via a unique approach in which the entire cell of a mesophile is converted into that of a thermophile. Previous studies have proposed that transformation to thermophily involves a limited number of genes which exert wide pleiomorphic effects [39]. These effects manifest themselves in the production of thermostable cellular components and products, possibly by specific mistranslation of messenger RNA $[39,40]$. Thus far, none of the enzymes purified from the B. subtilis $25 \mathrm{~S}$ HTG transformants have been shown to be products of specific thermophilic genes transferred from donor to recipient during the transformation of $25 \mathrm{~S}$ to thermophily [13]. Because the donor, B. caldolyticus $\mathrm{C} 2$, also produces a thermostable CDase, it was necessary to exclude the possibility that the thermostable $\mathrm{H}-17$ enzyme was 
actually encoded by a cointegrated gene from $B$. caldolyticus $C 2$. This enzyme has a different $\mathrm{M}_{\mathrm{r}}, \mathrm{pH}$ optimum, temperature optimum, and effect of 2-Me or EDTA on thermostability, when compared to the $\mathrm{H}-17$ enzyme. The $\mathrm{C} 2$ enzyme appears to achieve thermostability by a mechanism different than $\mathrm{H}-17$. The $\mathrm{H}-17$ enzyme may, in part, derive its greatest thermostability through disulfide bond formation, whereas $\mathrm{C} 2$ may, in part, derive its greatest thermostability by undergoing an altered conformation in the presence of EDTA. It is therefore believed that the H-17 and C2 enzymes are not products of the same gene, and that the B. caldolyticus $\mathrm{C} 2$ enzyme is not produced by the HTG transformant H-17.

In conclusion, amino acid sequence analyses of several mesophilic enzymes and their thermophilic counterparts have suggested that a few specific amino acid substitutions at critical regions may account for very subtle structural and conformational differences, that lead to large alterations in thermostability $[32,50,99,115]$. Cloning and nucleic acid sequencing of the $25 \mathrm{~S}, \mathrm{C} 2$, and $\mathrm{H}-17$ CDase genes will allow determination of the primary amino acid sequences. This will aid in elucidating the structural mechanisms for increased thermostability in these enzymes, which is a fundamental requirement for future protein engineering. 
CHAPTER 4

SUBSTRATE SPECIFITIES, AFFINITIES, AND

CLEAVAGE PATTERNS OF THE CYCLOMALTODEXTRINASE

FROM B. SUBTILIS 25S, B. CALDOLYTICUS C2,

AND THE $B$. SUBTILIS HIGH TEMPERATURE

GROWTH TRANSFORMANT H-17

Cyclomaltodextrinase (EC 3.2.1.54) (CDase) hydrolyses cyclodextrins (CDs) and linear maltodextrins much more rapidly than starch and other related polymers $[30,31,53]$. This chapter describes how the $25 \mathrm{~S}, \mathrm{C} 2$, and $\mathrm{H}-17$ enzymes described in Chapter 1, were further characterized by their classification as CDases. Hydrolytic activity was also determined to indicate whether the H-17 CDase has commercial application as a saccharifying and/or debranching enzyme.

\section{Materials and Methods}

\section{Organism and Growth Conditions}

B. subtilis $25 \mathrm{~S}, B$. caldolyticus $\mathrm{C} 2$, and $B$. subtilis $\mathrm{H}-17$ were grown aerobically to late log phase as described previously. 
Enzyme Purification and Standard Assay

The 25S, $\mathrm{C} 2$ and $\mathrm{H}-17$ enzymes were purified as described previously. To eliminate any possible low levels of contaminating enzyme activity during substrate hydrolysis assays, the 25S, C2, and H-17 enzymes were further purified by preparative native PAGE. Two Bio-Rad Mini-Protean II gels were stained for activity, as described previously, and the active band was precisely cut from each gel with a razor blade. The polyacrylamide strips were pulverized in $2-3 \mathrm{ml}$ of standard assay buffer in a hand-held, glass tissue homogenizer. The polyacrylamide suspension was centrifuged at $6,000 \mathrm{xg}$ for $5 \mathrm{~min}$ at $25^{\circ} \mathrm{C}$, and the supernatant removed. The polyacrylamide was washed with $2 \mathrm{ml}$ of the same buffer and recentrifuged. The supernatants were combined, sterile-filtered, and concentrated and equilibrated in standard assay buffer by ultrafiltration with an Amicon Centricon-30. Enzyme activity was determined by following the release of p-nitrophenol from p-nitrophenyl- $\alpha$-D-maltoside under previously described standard assay conditions.

\section{Substrate Specificity}

Enzyme activity was determined for p-nitrophenyl- $\alpha$-D-glucopyranoside (PNG), maltose (G2), maltotriose (G3), maltotetraose (G4), maltopentaose (G5), maltohexaose (G6), maltoheptaose (G7), isomaltose (IG2), isomaltotriose (IG3), panose (Pan), $\alpha$-cyclodextrin $(\alpha-C D), \beta$-cyclodextrin $\beta$-(CD), pullulan, soluble potato 
starch, potato amylose, and potato amylopectin. All malto-oligosaccharide and CD solutions were sterile-filtered and stored at $4^{\circ} \mathrm{C}$. All substrates were purchased from Sigma, and all substrate solutions were screened for purity using thin-layer chromatography.

Hydrolysis assays employed $10 \mathrm{mM}$ malto-oligosaccharides, $10 \mathrm{mM} \mathrm{CDs}$, or $2 \%$ polysaccharides. The reaction mixture $(500 \mu \mathrm{l})$ contained $470 \mu \mathrm{l}$ of substrate in $0.02 \% 2$-mercaptoethanol, $33 \mathrm{mM}$ phosphate buffer ( $\mathrm{pH} 7.5$ ), plus $30 \mu \mathrm{l}$ (0.05-0.1 units) of purified enzyme. Samples were incubated at $37^{\circ} \mathrm{C}, 60^{\circ} \mathrm{C}$, or $65^{\circ} \mathrm{C}$ for $25 \mathrm{~S}, \mathrm{C} 2$, or $\mathrm{H}-17$, respectively. The reaction was terminated at various intervals (5-120 $\mathrm{min}$ ) by boiling $100 \mu \mathrm{l}$ aliquots of the mixture for $3 \mathrm{~min}$. and then assayed for glucose and reducing power. Reducing sugars were determined by the dinitrosalicylic acid method [7], and glucose was determined with a peroxidase/ glucose oxidase colorimetric diagnostic kit (Sigma No. 510-A). Initial rates of hydrolysis were used to determine relative substrate specificities. Enzyme activity for PNG was determined under standard assay conditions.

$\underline{\mathrm{K}}_{\mathrm{m}}$ and $\mathrm{V}_{\max } \underline{\text { Determination }}$

Initial velocities were determined under the above assay conditions and were expressed as $\mu$ moles of reducing groups $/ \mathrm{min} / \mathrm{mg}$ protein, with glucose as the standard. Protein was determined by the method of Lowry et al. [45] with bovine serum albumin as the standard. $\mathrm{K}_{\mathrm{m}}$ and $\mathrm{V}_{\max }$ values were determined according 
to the Lineweaver-Burk method [42]. Soluble potato starch and potato amylopectin concentrations ranged over $0.2-4.0 \%$, while maltoheptaose and $\alpha$-cyclodextrin ranged over $0.2-10 \mathrm{mM}$.

\section{Thin-Layer Chromatography (TLC)}

The products of malto-oligosaccharide, $\mathrm{CD}$, and polysaccharide hydrolysis were analyzed by TLC using precoated Silica Gel G Redi/Plates (Fisher Scientific, Orlando). The plates were developed by a single ascent at $25^{\circ} \mathrm{C}$, with the solvent system n-butanol-ethanol-water (3:4:1.25, vol/vol) in a pre-equilibrated $10 \times 25 \times 29$ $\mathrm{cm}$ developing tank. Dried plates were stained for carbohydrate by spraying with a $6.5 \mathrm{mM}$ solution of $\mathrm{N}$-(1-naphthyl) ethylenediamine dihydrochloride in methanol containing $3 \%$ sulfuric acid [8], followed by heating at $110^{\circ} \mathrm{C}$ for $15 \mathrm{~min}$. Reference standards were commercial malto-oligosaccharides obtained from Sigma.

\section{$\underline{\text { Results and Discussion }}$}

The 25S, $\mathrm{C} 2$, or $\mathrm{H}-17$ CDase hydrolyzed p-nitrophenol- $\alpha$-D-maltoside in a linear fashion, regardless of enzyme or substrate concentration. This suggested that maltose and p-nitrophenol were released from PNM. If glucose and PNG were initially released from PNM, then the assay would show a delayed color formation due to the eventual hydrolysis of PNG. Neither enzyme was active against p-nitrophenyl- $\alpha$-D-glucopyranoside, maltose, isomaltose, isomaltotriose, or panose. 
Table 7 shows the experimental initial relative rates of hydrolysis of linear malto-oligosaccharides, $\alpha$ - and $B-C D$, and polysaccharides, as determined by reducing power and glucose liberation. The 25S, C2, and $\mathrm{H}-17$ enzymes demonstrated similar substrate specificities as the greatest increase in reducing power was produced with maltohexaose, maltoheptaose, and $\alpha$ - and B-CD, while starch, amylose, amylopectin, and pullulan were hydrolyzed significantly less (some data for $\mathrm{C} 2$ not shown). For either enzyme, hydrolysis of $\mathrm{G} 3$ produced the greatest quantity of glucose, while G7 hydrolysis produced the greatest increase in reducing power. It appeared that the enzyme preferred to sequentially cleave a maltose unit from the nonreducing end of the oligosaccharide, since less glucose was produced from the longer-chained substrates. However, there was, in part, random endoactivity since G4 and G6 hydrolysis also produced glucose, instead of only G2. Figure 8 shows the TLC analyses of the $10 \mathrm{~min}, 1 \mathrm{~h}$, and $3 \mathrm{~h}$ products of linear malto-oligosaccharide hydrolysis by either the $25 \mathrm{~S}, \mathrm{C} 2$, or $\mathrm{H}-17$ enzyme. The TLC results confirmed that the endo-hydrolysis by either enzyme was also, in part, nonspecific, since G4 was a low level intermediate produced from both G5 and G7 hydrolysis. Furthermore, in addition to $\mathrm{G} 2$ and $\mathrm{G} 4, \mathrm{G} 3$ was an intermediate produced from G6 hydrolysis. The subsequent hydrolysis of the G3 intermediate would account for the production of glucose from G6 cleavage. The enzymes also exhibited slight transglucosylase activity as seen with $\mathrm{G} 4$ hydrolysis. 
Table 7. Experimental relative rates of hydrolysis of malto-oligosaccharides, cyclodextrins, and polysaccharides by $B$. subtilis $25 S, B$. caldolyticus $\mathrm{C} 2$, and $B$. subtilis $\mathrm{H}-17$ cyclomaltodextrinase.

(expressed as \% maximum)

$\underline{\text { Substrate }}$

G2

G3

G4

G5

G6

G7

IG2, IG3, Panose

$\alpha$-Cyclodextrin

B-Cyclodextrin

Starch

Amylopectin

Amylose

Pullulan
Glucose Assay

\section{$\underline{25 \mathrm{~S}} \quad \underline{\mathrm{H}-17} \quad \underline{\mathrm{C} 2}$}

$\begin{array}{rrr}0 & 0 & 0 \\ 100 & 100 & 100 \\ 11 & 36 & 41 \\ 45 & 52 & 71 \\ 29 & 39 & 64 \\ 32 & 45 & 65 \\ 0 & 0 & 0\end{array}$

$\underline{\text { Reducing Sugar Assay }}$

$\underline{25 \mathrm{~S}} \underline{\mathrm{H}-17} \quad \underline{\mathrm{C} 2}$

$\begin{array}{rrr}0 & 0 & 0 \\ 20 & 16 & 24 \\ 35 & 43 & 45 \\ 67 & 63 & 85 \\ 81 & 68 & 98 \\ 100 & 100 & 100 \\ 0 & 0 & 0\end{array}$

$85 \quad 90$

$95 \quad 70$

$10 \quad 11$

$22 \quad 25$

$12 \quad 10$

$7 \quad 7$ 


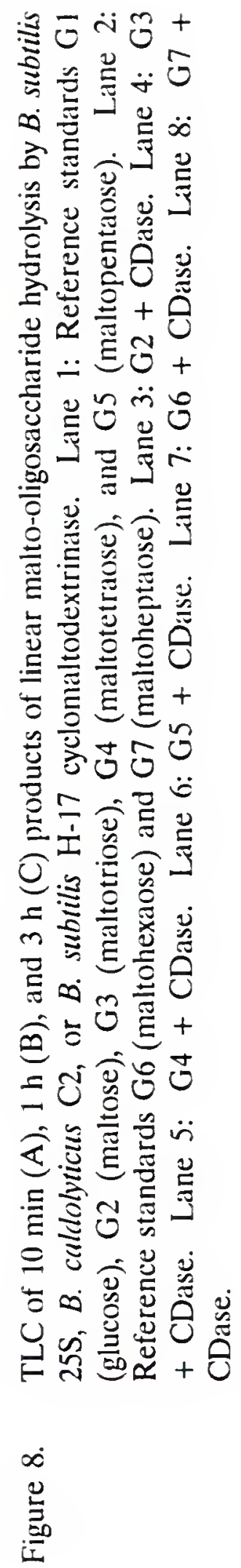




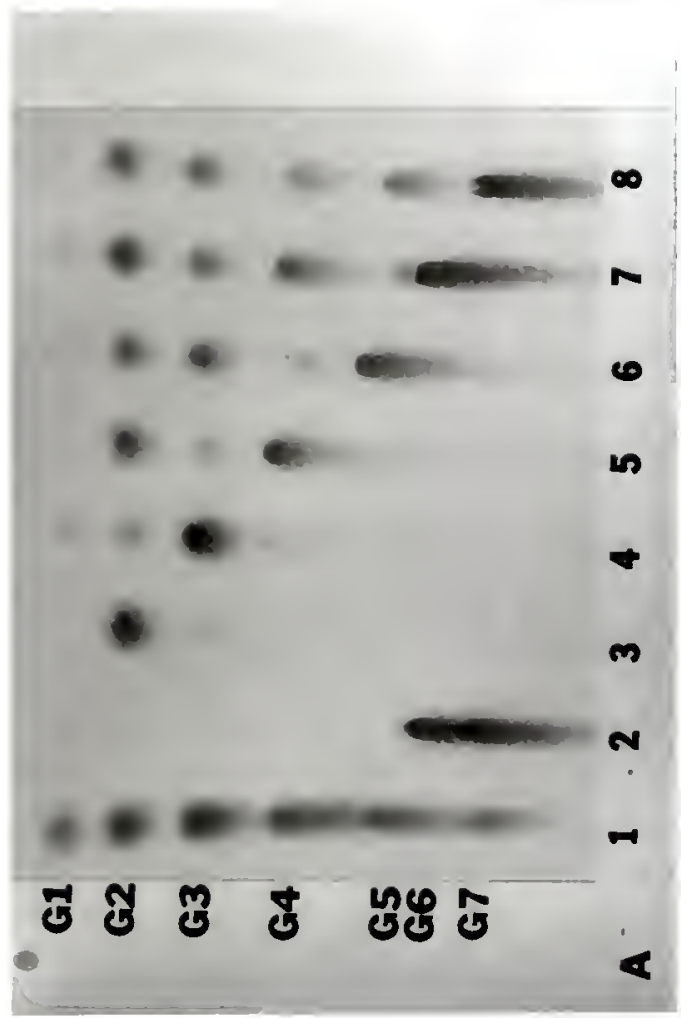


The $25 \mathrm{~S}$ and $\mathrm{H}-17 \mathrm{~K}_{\mathrm{m}}$ and $\mathrm{V}_{\max }$ values for maltoheptaose, $\alpha-\mathrm{CD}$, starch, and amylopectin are presented in Table 8. Both enzymes showed greater affinities for maltoheptaose and $\alpha-\mathrm{CD}$ than for starch and amylopectin. Consequently, the $25 \mathrm{~S}$ and H-17 enzymes were classified as cyclomaltodextrinases, based on substrate specificity and affinity. It may be inferred that the C2 enzyme is also a cyclomaltodextrinase based upon the enzyme's similar characteristics. One may note that the $\mathrm{H}-17 \mathrm{CD}$ ase attacked $\alpha-\mathrm{CD}$ faster than $\mathrm{B}-\mathrm{CD}$, while the $25 \mathrm{~S}$ CDase cleaved $B-C D$ faster than $\alpha-C D$. Perhaps the increase in the H-17 enzyme's internal hydrophobicity over its $25 \mathrm{~S}$ counterpart tightens the molecule as a whole through strengthened hydrophobic interaction. While this may enhance thermostability, the larger ring structure of $B-C D$ may become less accessible than $\alpha-\mathrm{CD}$ to the active site of the $\mathrm{H}-17$ enzyme.

Figure 9 shows the TLC analysis of the 20 min hydrolysis products of $\alpha$ - and B-CD, and $1.5 \mathrm{~h}$ cleavage products of amylose, amylopectin, and starch by either the $25 \mathrm{~S}$ or H-17 enzyme. TLC indicates that the enzymes initially open the ring of $\alpha$ - or $B-C D$ forming a linear molecule with the corresponding number of glucose units. Degradation of the linear molecule to shorter malto-oligosaccharides follows, with the accumulation of maltose as the final main product. However, it is unclear whether the hydrolysis of $\mathrm{CDs}$ by $25 \mathrm{~S}$ or $\mathrm{H}-17$ CDase proceeds via a multiple attack, or a multiple site attack model [20]. The enzymes appear to exhibit a preferred attack model [20] for starch, amylopectin, and amylose, in which maltose 
Table 8. $\quad \mathrm{K}_{\mathrm{m}}$ and $\mathrm{V}_{\max }$ values of $B$. subtilis $25 \mathrm{~S}$ and $B$. subtilis $\mathrm{H}-17$ cyclomaltodextrinase.

$\underline{25 \mathrm{~S}}$

Substrate

$\mathrm{V}_{\max }^{\mathrm{a}}$

$\mathrm{K}_{\mathrm{m}}$

$\underline{\mathrm{H}-17}$

$\mathrm{K}_{\mathrm{m}} \quad \mathrm{V}_{\max }^{\mathrm{a}} \quad \mathrm{K}_{\mathrm{m}} \quad \mathrm{V}_{\max }^{\mathrm{a}}$

Maltoheptaose

$1.1 \mathrm{mg} / \mathrm{ml}(0.96 \mathrm{mM}) \quad 42$

$1.0 \mathrm{mg} / \mathrm{ml}(0.91 \mathrm{mM}) \quad 45$

$\alpha$-Cyclodextrin

$1.1 \mathrm{mg} / \mathrm{ml}(1.10 \mathrm{mM}) \quad 36$

$0.9 \mathrm{mg} / \mathrm{ml}(0.93 \mathrm{mM}) \quad 33$

Starch

$20 \mathrm{mg} / \mathrm{ml}$

15

$22 \mathrm{mg} / \mathrm{ml}$

16

Amylopectin

$20 \mathrm{mg} / \mathrm{ml}$

20

$20 \mathrm{mg} / \mathrm{ml}$

17

a

$\mu$ moles of reducing groups $/ \mathrm{min} / \mathrm{mg}$ of protein 
Figure 9. TLC of $20 \mathrm{~min}$ hydrolysis products of CDs and $1.5 \mathrm{~h}$ hydrolysis products of polysaccharides by $B$. subtilis $25 \mathrm{~S}$ or $B$. subtilis $\mathrm{H}-17$ cyclomaltodextrinase. Lane 1: reference standards G1 (glucose), G2 (maltose), G3 (maltotriose), G4 (maltotetraose), G5 (maltopentaose), G6 (maltohexaose). Lane 2: $\alpha$-cyclodextrin + CDase. Lane 3: $\beta$ cyclodextrin + CDase. Lane 4: amylose + CDase. Lane 5: amylopectin + CDase. Lane 6: starch + CDase. Lane 7: reference standards G1 and IG2 (isomaltose).

Figure 10. TLC of products of pullulan hydrolysis by $B$. subtilis $25 \mathrm{~S}$ and $B$. subtilis H-17 cyclomaltodextrinase. Lane 1: Reference standards G1 (glucose), G2 (maltose), and G3 (maltotriose). Lane 2: Pullulan (no enzyme). Lanes 3 and 4: $30 \mathrm{~min}$ and $2 \mathrm{~h}$ hydrolysis of pullulan by 25S CDase, respectively. Lanes 5 and 6: $30 \mathrm{~min}$ and $2 \mathrm{~h}$ hydrolysis of pullulan by $\mathrm{H}-17$ CDase, respectively. Lane 7: Reference standards IG2 (isomaltose) and PAN (panose). 

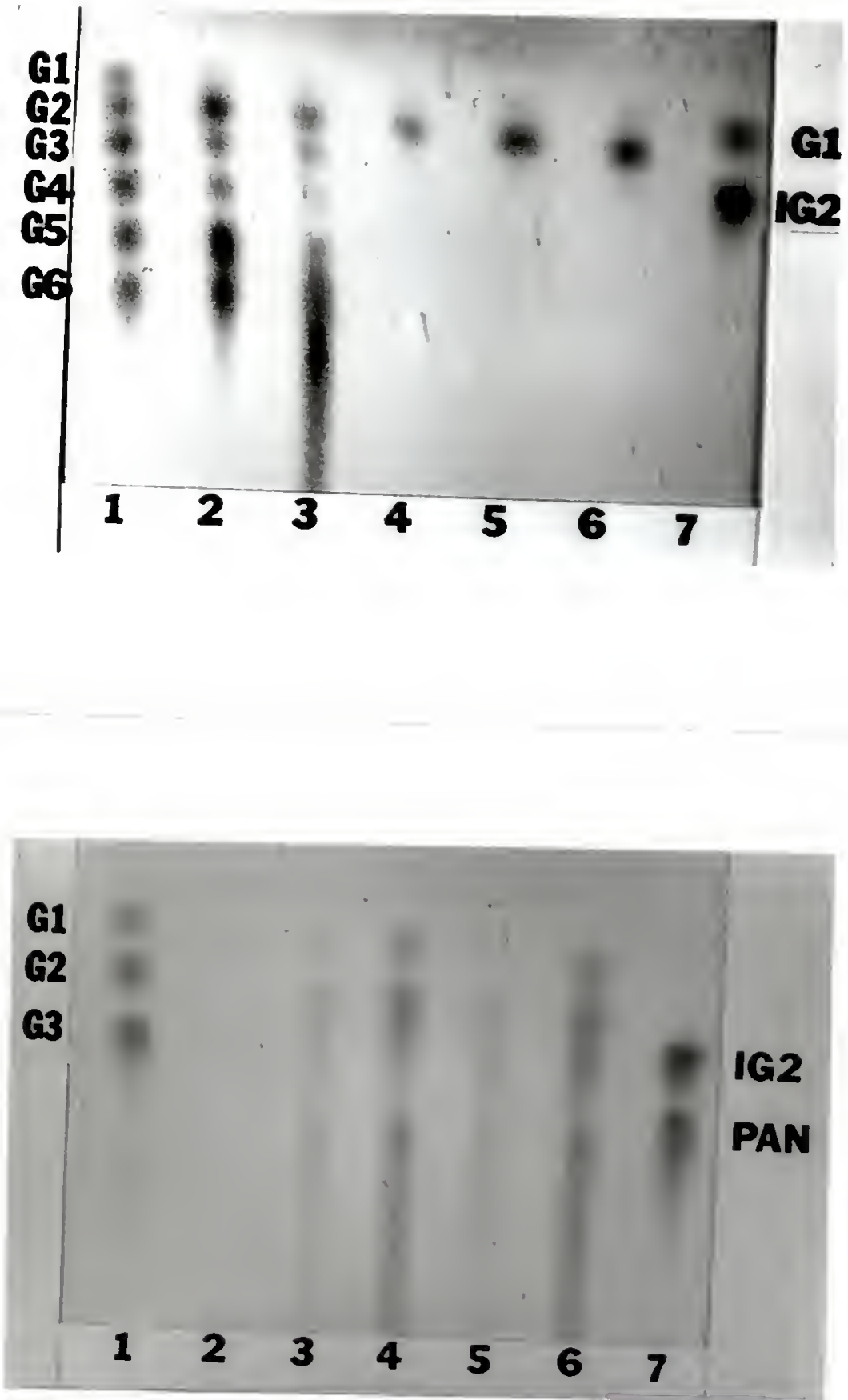
is the main end product. TLC indicates these polysaccharides were degraded in exo-fashion by preferential cleavage of maltose units from non-reducing ends, although small amounts of glucose were detectable.

Both $25 \mathrm{~S}$ and $\mathrm{H}-17$ CDase's ability to cleave $\alpha-1,4$ bonds of pullulan, together with their rapid attack of $\alpha$ - and $\beta-C D$ rings indicate that the enzymes do not necessarily require a non-reducing terminal end and that their action can be of the endo-type. Although the hydrolysis of pullulan was slow, it's 1,6-branch structure suggests that the presence of amylopectin's 1,6-branch points, may be a factor in both $25 \mathrm{~S}$ and H-17 CDase's slightly faster cleavage of amylopectin over starch or amylose. Figure 10 shows TLC analysis of the $30 \mathrm{~min}$ and $2 \mathrm{~h}$ products of pullulan hydrolysis by $25 \mathrm{~S}$ and H-17 CDase. It appears both enzymes produced glucose, maltose, and panose from pullulan. Identical cleavage patterns were observed for the C2 CDase. Traditional pullulanases hydrolyze only the $\alpha-1,6$-glycosidic linkages of pullulan, releasing maltotriose. Consequently, the $25 \mathrm{~S}, \mathrm{H}-17$, and C2 CDases demonstrated either isopullulanase (hydrolysis of $\alpha-1,4$ linkages to produce isopanose), or neopullulanase (hydrolysis of $\alpha-1,4$ linkages to produce panose) activity [72].

The $\mathrm{C} 2$ and $\mathrm{H}-17$ thermostable CDase are very similar to the B. thermoamyloliquefaciens KP 1071 thermostable $\alpha$-amylase II [94], and the B. stearothermophilus KP 1064 thermostable maltogenic $\alpha$-amylase [92] in that they all, (a) behave as low active, exo-acting, maltogenic enzymes against starch, amylose, 
and amylopectin, (b) demonstrate pullulan hydrolase activity with panose as a final product, and (c) exhibit a highly-active endo-type attack on $\mathrm{CDs}$, in addition to other similar physiochemical characteristics. The 25S, H-17, and C2 CDase also resemble the $B$. coagulans cyclodextrinase $[30,31]$, which hydrolyses $C D s$ and linear malto-oligosaccharides much faster than starch polysaccharides, and the B. stearothermophilus TRS40 [33] neopullulanase which produces panose, maltose and glucose from pullulan, and maltose from starch. However, the H-17 CDase is different from the B. subtilis saccharifying $\alpha$-amylase [20] in that the latter (a) removes maltotriosyl units from the non-reducing end of malto-oligosaccharides [55], (b) hydrolyses maltopentaose and maltohexaose at a very slow rate [61], (c) hydrolyses maltose [80], and (d) produces significant amounts of glucose from starch $[20]$.

Current problems in the industrial production of glucose syrups include the large $\mathrm{pH}$ and temperature drop required for the transition from starch liquefaction to maltodextrin saccharification, and the unacceptably long holding times (48-96 h) required for saccharification by fungal glucoamylase $[20,24,72]$. Unfortunately the H-17 CDase does not appear to fulfill the need for a neutrophilic, highly thermostable glucoamylase. However, the enzyme does have potential applications in beer brewing and in the production of high maltose (high conversion) syrups following $\alpha$-amylase liquefaction, although the latter would require the removal of calcium ions subsequent to liquefaction. High maltose syrups in food system 
applications have several desirable properties such as resistance to color formation and crystallization, low hygroscopicity, mild sweetness, no aftertaste, low viscosity, good heat stability, and easy fermentability. Applications of high maltose syrups include confectioneries, jellies, jams, dessert formulations, baking and brewing, and intravenous feeding (no glucose shock) [20,24]. However, major factors which would limit the commercial application of the $\mathrm{H}-17$ CDase include the low amounts of CDase produced by $B$. subtilis, and sufficient purification of the CDase from the multitude of other B. subtilis intracellular and cell wall-bound enzymes. 


\section{CHAPTER 5}

CLONING OF THE CYCLOMALTODEXTRINASE

GENE FROM B. SUBTILIS HIGH TEMPERATURE GROWTH TRANSFORMANT H-17

The CDase from $B$. subtilis $\mathrm{H}-17$ is a novel type of $\alpha-1,4$ glucan hydrolase. Unfortunately, the limitations of low yields and tedious purification may hinder the commercial application of the H-17 CDase. However, the enzyme's potential could be improved by cloning the CDase gene and studying its expression in order to develop genetic strategies to amplify production of the enzyme. Subsequent development of a host-vector system, which would direct extracellular secretion of the cloned CDase, could simplify enzyme purification. Additional investigations would (a) determine if the cloned H-17 CDase maintains its thermostability in a mesophilic host, and (b) may determine the origin of the H-17 CDase gene by its hybridization to genomic DNA from B. subtilis $25 \mathrm{~S}$ or $B$. caldolyticus $\mathrm{C} 2$. No reports to date have genetically characterized a bacterial CDase gene by cloning and sequencing. This chapter describes the approaches taken to clone the H-17 CDase gene and the problems encountered in its expression in the hosts $E$. coli and B. subtilis. 


\section{Materials and Methods}

\section{Bacterial Strains and Growth Media}

For preparation of genomic DNA, B. subtilis $\mathrm{H}-17$ was grown aerobically to late $\log$ phase as previously described. E. coli DH5a and B. subtilis YB886 were maintained on Luria-Broth (LB) [46] agar. E. coli XL1-Blue carrying the $l a c 1^{\mathrm{q}}$ gene on the F' episome was maintained on LB agar supplemented with $12.5 \mu \mathrm{g} / \mathrm{ml}$ of tetracycline. E. coli transformants carrying the pUC18 plasmid were grown on LB agar supplemented with $50 \mu \mathrm{g} / \mathrm{ml}$ of ampicillin (LA agar). LA broth was the same medium without agar. B. subtilis YB886 transformants carrying the pPL708 plasmid were grown on LB agar supplemented with $10 \mu \mathrm{g} / \mathrm{ml}$ of kanamycin (LK agar). LK broth was the same medium without agar. E. coli XL1-Blue transformants carrying the pUC18 plasmid were grown on LB supplemented with $12.5 \mu \mathrm{g} / \mathrm{ml}$ of tetracycline plus $50 \mu \mathrm{g} / \mathrm{ml}$ of ampicillin (LAT agar). All antibiotics were sterile-filtered and added to media cooled to $50^{\circ} \mathrm{C}$.

\section{Agarose Gel Electrophoresis and Southern Blot Procedure}

All restriction enzyme digests of chromosomal or plasmid DNA preparations were analyzed by agarose gel electrophoresis for $2.5 \mathrm{~h}$ at $55 \mathrm{~V}$ using a Bio-Rad Mini Sub Cell. All gels were 0.8\% agarose in running buffer (TAE buffer), which was $0.04 \mathrm{M}$ Tris-acetate, $0.001 \mathrm{M}$ EDTA ( $\mathrm{pH} 8.0)$, containing $1 \mu \mathrm{g} / \mathrm{ml}$ of ethidium bromide. Preparative gels were in TAE buffer and consisted of $0.8 \%$ high purity 
Seakem LE agarose (FMC BioProducts, Rockland, ME). The molecular weight

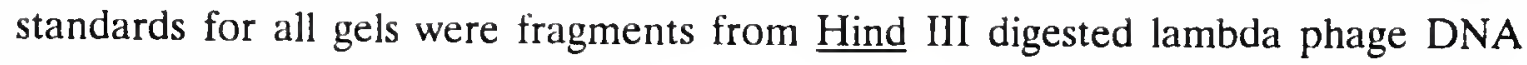
(Promega Corp., Madison, WI).

Southern Blots were carried out by the capillary transfer method as previously described [75], with the following modifications. The DNA was denatured by soaking the agarose gel, with gentle shaking, in several volumes of $1.5 \mathrm{M} \mathrm{NaCl}, 0.5 \mathrm{M} \mathrm{NaOH}$ for at least $1 \mathrm{~h}$, or until the tracking dye disappeared. The gel was neutralized by soaking, with gentle shaking, in several volumes of $1 \mathrm{M}$ Tris- $\mathrm{HCl}, 1.5 \mathrm{M} \mathrm{NaCl}(\mathrm{pH} 8.0$ ) for $1 \mathrm{~h}$. Two or three Scotch-Brite scour pads, stacked approximately $0.5-0.75$ inches, high were immersed to the top edge in $20 \times \mathrm{SSC}$ ( $3 \mathrm{M}$ sodium chloride, $0.3 \mathrm{M}$ trisodium citrate, $\mathrm{pH}$ 7.0). The neutralized gel was sandwiched on top of the scour pads and DNA was transferred overnight onto a Magnagraph nylon membrane (Micron Separations, Inc., Westboro, MA). After transfer, the nylon membrane was not washed, but immediately baked for $1 \mathrm{~h}$ at $>80^{\circ} \mathrm{C}$. The membrane was then used for DNA hybridization analysis.

\section{Preparation and Digestion of Chromosomal DNA}

Two liters of B. subtilis $\mathrm{H}-17$ cells were centrifuged at 9,000 $\mathrm{x} g$ in a Sorvall $\mathrm{RC}-5 \mathrm{~B}$ GSA rotor, for $15 \mathrm{~min}$ at $4^{\circ} \mathrm{C}$. The pellet (approx. $2 \mathrm{~g}$ ) was washed in $33 \mathrm{mM}$ phosphate-buffered saline solution ( $\mathrm{pH} 7.2$ ) (PBS) and recentrifuged. In a sterile $50 \mathrm{ml}$ centrifuge tube, the pellet was resuspended in $10 \mathrm{mM}$ EDTA, 
$25 \mathrm{mM}$ Tris- $\mathrm{HCl}, 10 \%$ glycerol $(\mathrm{pH} 8.0)$ to give a concentration of $100 \mathrm{mg}$ wet wt cells/ml. Lysozyme was added to give a final concentration of $1 \mathrm{mg} / \mathrm{ml}$ and the suspension was incubated overnight at $37^{\circ} \mathrm{C}$. DNase-free Proteinase $\mathrm{K}$ was added to give a final concentration of $200 \mu \mathrm{g} / \mathrm{ml}$ and the solution was incubated for 12 h at $50^{\circ} \mathrm{C}$. A $10 \%$ solution of $\mathrm{N}$-laurylsarcosine-sodium salt was added at a level of $100 \mu 1 / \mathrm{ml}$ of reaction mixture, and the solution was incubated overnight at $50^{\circ} \mathrm{C}$. Two volumes of $95 \%$ ethanol were added, and the precipitated DNA was spooled out, rinsed with $70 \%$ ethanol, and dried under vacuum in a sterile $50 \mathrm{ml}$ screw cap centrifuge tube. The DNA was dissolved in $33 \mathrm{ml}$ of $10 \mathrm{mM}$ Tris- $\mathrm{HCl}, 1 \mathrm{mM}$ EDTA ( $\mathrm{pH}$ 8.0) (TE buffer), and cesium chloride was added to a final concentration of $1 \mathrm{~g} / \mathrm{ml}$. The solution was centrifuged at $45,000 \times \mathrm{g}$, for $22 \mathrm{~h}$ at $20^{\circ} \mathrm{C}$, with a T865 rotor in a Sorval OTD-2 ultracentrifuge. The centrifuge tube was punctured at top and bottom with a 16 gauge needle, and drops of DNA were collected based upon a rapid increase in viscosity/stringiness. The DNA solution (approx. $3 \mathrm{ml}$ ) was dialyzed for $24 \mathrm{~h}$ against $4 \times 1$ liter volumes of TE buffer. DNA concentration was determined by its absorbance at $260 \mathrm{~nm}$, and purity by the absorbance ratio of $260 \mathrm{~nm} / 280 \mathrm{~nm}$. The DNA solution was stored at $-20^{\circ} \mathrm{C}$.

The $\mathrm{H}-17$ chromosomal DNA was partially digested with the restriction enzyme Sau 3A (Promega) as previously described [5], with the following modifications. Approximately $50 \mu \mathrm{g}$ of DNA in $500 \mu \mathrm{l}$ of $1 \mathrm{x}$ reaction buffer was dispensed in $50 \mu \mathrm{l}$ aliquots among eight microfuge tubes. To the remaining 
$100 \mu \mathrm{l}$ in tube one, $2 \mu \mathrm{l}$ of Sau $3 \mathrm{~A}$ was added. Enzyme activity was sequentially diluted by removing $50 \mu \mathrm{l}$ from tube one to tube two, and from tube two to tube three, etc. The tubes were incubated at $37^{\circ} \mathrm{C}$ for $20 \mathrm{~min}$, and the reactions terminated by the addition of $5 \mu \mathrm{l}$ of $0.5 \mathrm{M}$ EDTA and heating at $65^{\circ} \mathrm{C}$ for $10 \mathrm{~min}$. H-17 DNA was completely digested with the restriction enzymes $\underline{\text { Pst }}$ I, Bam HI,

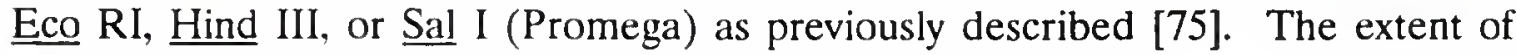
each digestion was analyzed by agarose gel electrophoresis.

\section{Construction and Amplification of Gene Libraries}

The Sau $3 \mathrm{~A}$ digestion that gave maximal size distribution at the 4-9 kilobase (kb) level was electrophoresed on a preparative agarose gel. The portion of gel containing the lambda Hind III standards in the outside lane was cut from the geI with a razor blade, visualized under UV light, and the $4.4 \mathrm{~kb}, 6.6 \mathrm{~kb}$, and $9.4 \mathrm{~kb}$ standards were marked. This strip of agarose was placed adjacent to the rest of the gel in order to cut out agarose sections that contained 4-6 kb fragments and 6-9 $\mathrm{kb}$ fragments. A similar procedure was employed to isolate fragments from either Eco RI, Bam HI, or Pst I complete digests from preparative agarose gels. The portion of gel containing the lambda Hind III standards in the outside lane, plus one lane-equivalent of the complete DNA digest was Southern blotted. The CDase gene was identified by Southern blot hybridization (see Construction and Detection of DNA Probe), and the nylon membrane was placed adjacent to the 
remaining preparative gel. The agarose section that contained fragments which hybridized to the DNA probe was precisely cut from the remainder of the gel. The narrow strips of agarose that contained 4-6 kb, 6-9 kb, or DNA probe-positive fragments were placed in microfilterfuge tubes with $0.45 \mu \mathrm{m}$ nylon-66 membranes (Rainin Instrument Co., Woburn, MA). The gel segments were gently macerated in the microfilterfuge tubes with a sterile wooden applicator stick, and the tubes were frozen at $-20^{\circ} \mathrm{C}$. Upon thawing, the tubes were centrifuged at $12,000 \mathrm{xg}$ for $3 \mathrm{~h}$. Filtrates containing the same DNA fragments were pooled and concentrated to $100 \mu \mathrm{l}$ by extraction with n-butanol [75]. The DNA solutions were extracted with an equal volume of phenol/chloroform/iso-amyl alcohol (25:24:1), and then with an equal volume of chloroform/ isoamyl alcohol (24:1) [75]. The DNA was precipitated with 2.5 volumes $(250 \mu \mathrm{l})$ of $95 \%$ ethanol, and pelleted by centrifugation at $12,000 \mathrm{xg}$ for $15 \mathrm{~min}$. The pellet was washed with $70 \%$ ethanol, centrifuged at $12,000 \times \mathrm{g}$ for $5 \mathrm{~min}$, and the pelleted DNA was dissolved in $50 \mu \mathrm{l}$ of TE buffer [75]. The DNA fragment solutions were stored at $-20^{\circ} \mathrm{C}$ until subsequent ligations.

The plasmid cloning vectors (Figure 11) for E. coli and B. subtilis were pUC18 (Boehringer Mannheim, Indianapolis, IN) and pPL708 (Dr. Paul Lovett, University of Maryland), respectively. Approximately $5 \mu \mathrm{g}$ of pUC18 or pPL708 was linearized by either a $\underline{\text { Pst }} \mathrm{l}$, $\underline{\text { Bam }} \mathrm{HI}$, or Eco RI digest as previously described 
Figure 11. Genetic map of E. coli plasmid cloning vector pUC18 (top) and B. subtilis plasmid cloning vector pPL708 (bottom). 

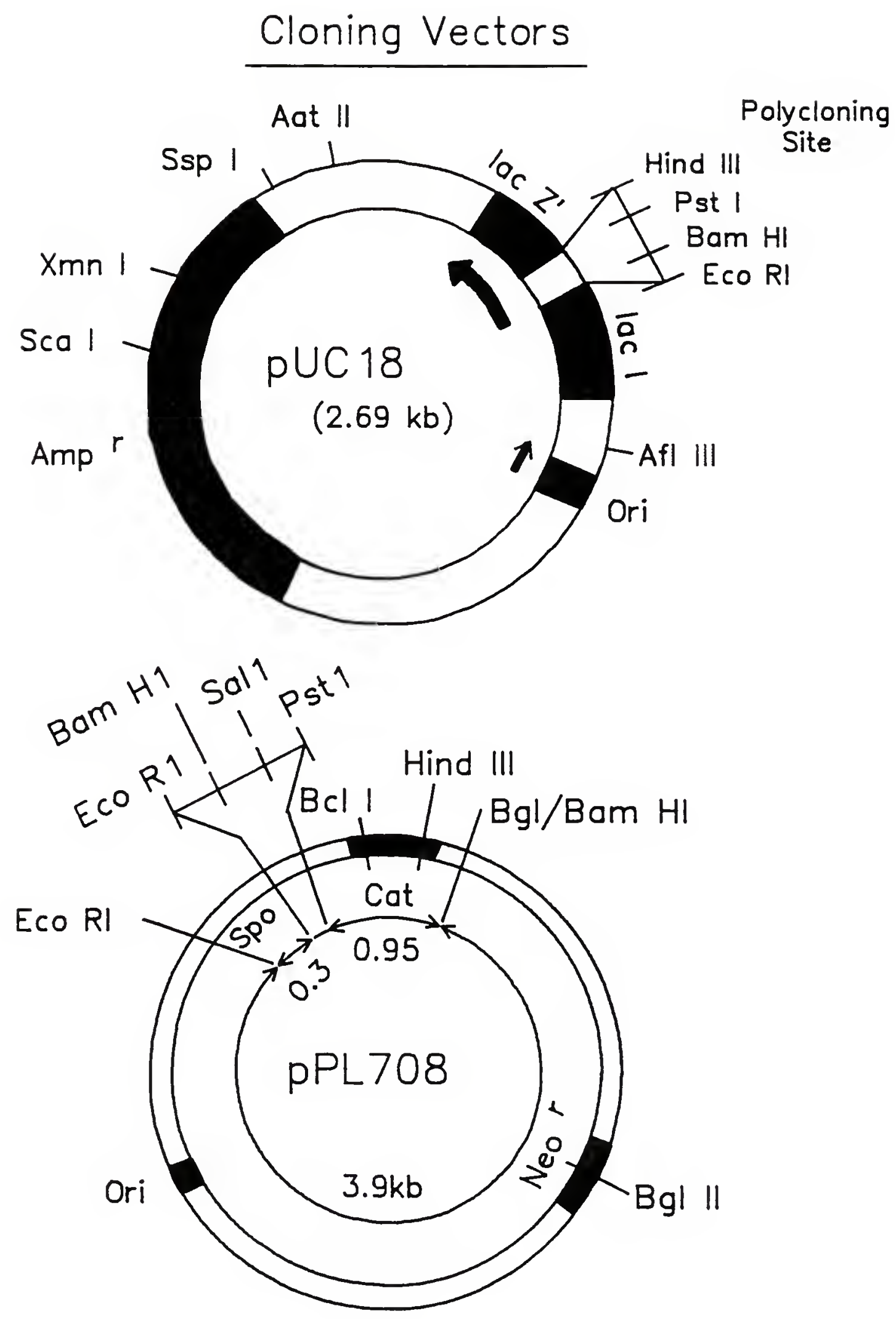
[75]. Linearized pUC18 was dephosphorylated with calf intestinal alkaline phosphatase (Promega) according to manufacturer's recommendations. Linearized pPL708 was not dephosphorylated. Linearized, dephosphorylated pUC18, and linearized pPL708 were each phenol/chloroform extracted, precipitated with 2.5 volumes of $95 \%$ ethanol, and redissolved in $50 \mu \mathrm{l}$ of TE buffer. For all ligations, pUC18 $(0.5 \mu \mathrm{g})$ and insert fragments were mixed 2:1, while pPL708 $(0.2 \mu \mathrm{g})$ and insert fragments were mixed $1: 3$. The $4-6 \mathrm{~kb}$ or $6-9 \mathrm{~kb}$ Sau $3 \mathrm{~A}$ fragments were ligated into the Bam HI site of pUC18, by T4 DNA ligase (Promega), as previously described [75]. In individual ligations, the $\underline{\text { Pst }} \mathrm{I}, \underline{\mathrm{Bam}} \mathrm{HI}$, or Eco RI probe-positive fragments were ligated into their respective restriction sites in either pUC18 or pPL708, by T4 DNA ligase. Each gene library was stored at $-20^{\circ} \mathrm{C}$ until host transformation.

E. coli DH5 $\alpha$ was made competent for transformation by the calcium chloride procedure [75]. Competent E. coli cells were transformed with separate pUC18 $\underline{\text { Sau }} 3 \mathrm{~A}, \underline{\text { Pst }}$ I, Bam HI, or Eco RI gene libraries as previously described [75], with the following modifications. After competent cells, mixed with plasmid DNA, were incubated on ice for $30 \mathrm{~min}$, the cells were incubated in a $37^{\circ} \mathrm{C}$ water bath for $2 \mathrm{~min}$ followed by incubation at room temperature for $10 \mathrm{~min}$. Luria broth was then added to the transformed cells and recovery was for $1 \mathrm{~h}$ at $37^{\circ} \mathrm{C}$. After recovery, transformants were selected by plating the cells on LA agar and incubating at $37^{\circ} \mathrm{C}$ for $20 \mathrm{~h}$. Colonies that were ampicillin resistant carried the 
pUC18 vector. Each gene library was now amplified, with approximately 10,000 colonies/library. The colonies were scraped from the LA plates with Luria broth, pooled by centrifugation at $5,000 \mathrm{xg}$ for $10 \mathrm{~min}$, and plasmid DNA was isolated from the pelleted cells by the alkaline lysis method [75]. Each amplified plasmid library was stored at $-20^{\circ} \mathrm{C}$, during which aliquots were removed to screen for the CDase gene by retransformation of E. coli. The amplified $\underline{\text { Pst I, Bam HI, and Eco }}$ RI libraries were analyzed for the presence of the CDase gene, by digestion with the respective enzymes to liberate the inserts from pUC18, followed by Southern blot hybridization.

B. subtilis YB886 was made competent for transformation (Dr. M. Barbosa, Univerity of Florida, personal communication) by growing cells to late log phase in Spizizen's minimal salts medium supplemented with casamino acids, yeast extract, glucose, calcium chloride, and magnesium chloride [10]. Competent $B$. subtilis cells were transformed with separate pPL708 $\underline{\text { Pst } I, ~ B a m ~ H I, ~ a n d ~ E c o ~ R I ~ l i b r a r i e s ~ b y ~}$ incubating cells with DNA at $37^{\circ} \mathrm{C}$ for $40 \mathrm{~min}$. Yeast extract and glucose $(1 \%$ an $2 \%$ final conc., respectively) were added to the transformed cells and recovery was for $1.5 \mathrm{~h}$, with shaking at $37^{\circ} \mathrm{C}$. Transformants were selected by plating the cells on LK agar and incubating at $37^{\circ} \mathrm{C}$ for $20 \mathrm{~h}$. Colonies that were kanamycin resistant carried the vector pPL708. The colonies were directly screened for the CDase gene without amplification of each gene library. 


\section{Screening Gene Libraries with Substrate Media}

All the pUC18 libraries were screened for the H-17 CDase gene by plating E. coli $\mathrm{DH} 5 \alpha$ transformants onto LA agar plates supplemented with various carbohydrate substrates. If no colonies initially demonstrated enzyme activity, colonies were made "leaky" by exposing plates to chloroform. Plates were uncovered, inverted, and placed over a wire mesh screen in a wide pan filled with $40 \mathrm{ml}$ of chloroform. The pan was tightly covered with aluminum foil, and plates were removed approximately 15 min later, or until the plastic just started to become soft. The plates were then reincubated at $37^{\circ} \mathrm{C}$ in a humid environment for 24-48 h. The pPL708 libraries were not screened for H-17 CDase activity using substrate media because B. subtilis YB886 produces its own CDase.

Pullulan-Reactive Red (PRR)-LA and Maltrin-Reactive Red (MRR)-LA agarose plates were made as previously described [68], with the following modifications. Pullulan (Hayashibara, Okayama, Japan) or Maltrin M050 (Grain Processing Corp, Muscatine, IA), a maltodextrin solid with average degree of polymerization of 22 , were covalently labelled with the dye Reactive Red 120 (Sigma). To remove excess salts and dye, the PRR was exhaustively dialyzed against distilled water, while MRR was precipitated with 95\% ethanol (50\% final conc.), centrifuged at 5,000 $\mathrm{xg}$ for $10 \mathrm{~min}$, and redissolved in distilled water. The procedure was repeated several times until the supernatant was clear. The PRR or MRR solution was diluted to $1 \%$ to make Luria broth. Agar was substituted 
with $1 \%$ agarose and the solution was autoclaved for $15 \mathrm{~min}$ before adding ampicillin. Hydrolysis of pullulan or maltrin would produce a clear zone around the colony while the surrounding media remained red.

Cyclodextrin-Phenol Red (CPR)-LA agar plates contained $1 \% \alpha-$ or B-CD (American Maize-Products Co., Hammond, IN) and $0.01 \%$ phenol red. Luria broth plus phenol red and $1.5 \%$ agar was adjusted to $\mathrm{pH} 7.7$, autoclaved for $15 \mathrm{~min}$, and sterile-filtered $\mathrm{CD}$ added. If CDase-producing E. coli transformants could degrade the $\mathrm{CD}$ to maltose and glucose, then the host would then ferment the available sugars to acid, which would cause phenol red to turn yellow around the colony. The system was developed using $1 \%$ glucose as a sole carbohydrate. CPR-LA broth was the same medium without agar. A change in broth color from red to yellow would also indicate acid production from utilization of CDs.

Starch-LA and p-nitrophenyl- $\alpha$-D-maltoside (PNM)-LA agar plates contained $1 \%$ soluble starch and $1 \mathrm{mg} / \mathrm{ml}$ PNM, respectively. Starch-LA plates were inverted, a few crystals of iodine were placed on the cover, and the plate was closed to allow iodine vapors to diffuse into the agar. Hydrolysis of starch would produce a clear halo around the colony while the surrounding agar turns purple due to the starchiodine complex. Hydrolysis of PNM would produce a yellow colony with a yellow halo due to the release of p-nitrophenol. 


\section{Construction and Detection of DNA Probe}

Highly purified $\mathrm{H}-17$ CDase from preparative native PAGE underwent TrisTricine-SDS PAGE with the previously described buffer system [78]. Protein was Western blotted onto a polyvinylidene difluoride (PVDF) membrane at $90 \mathrm{~V}$, for $2.5 \mathrm{~h}$ at $4^{\circ} \mathrm{C}$, with a Bio-Rad Trans-Blot Electrophoretic Transfer Cell. The transfer buffer was $10 \mathrm{mM}$ MES, pH 6, 10\% methanol. The PVDF membrane was stained for $5 \mathrm{~min}$ in $0.1 \%$ Coomassie Blue R-250 in 50\% methanol, destained in $50 \%$ methanol, $10 \%$ acetic acid for 3-5 min, rinsed in distilled water $3 \times 5$ min, air dried, and stored at $-20^{\circ} \mathrm{C}$. The $55,000 \mathrm{M}_{\mathrm{r}}$ band from four separate lanes was excised from the membrane and sequenced by Edman degradation on an Applied Biosystems Model 470A gas phase protein microsequencer, by the Protein Chemistry Core Facility, University of Florida. Amino acids were identified by reverse phase HPLC using a Novapak C-18 column. Based on the $\mathrm{N}$-terminal amino acid sequence, a degenerate DNA oligonucleotide was synthesized on an Applied Biosystems 380B Synthesizer, by the DNA Synthesis Core Laboratory, University of Florida.

The oligonucleotide $\left(\begin{array}{ll}6 & \mu \mathrm{g}\end{array}\right)$ was nonradioactively end-labelled with digoxigenin-11-dUTP (Boehringer Mannheim) by terminal transferase (Boehringer Mannheim), as recommended by the manufacturer. The labelled probe was ethanol precipitated, dissolved in $100 \mu \mathrm{l}$ of TE buffer containing $0.1 \%$ SDS, and stored at $-20^{\circ} \mathrm{C}$. 
Southern blot hybridizations were performed as recommended by the Genius $^{\mathrm{TM}}$ Nonradioactive DNA Detection Kit (Boehringer Mannheim). The ovenbaked Southern blot was prehybridized in $100 \mathrm{ml}$ of hybridization solution without probe at $68^{\circ} \mathrm{C}$ for $1 \mathrm{~h}$. The membrane was sealed in a Dow Heavy Duty Ziploc Freezer Bag and submerged in a shaking water bath $(50 \mathrm{rpm})$. Labelled probe was diluted in $10 \mathrm{ml}$ of hybridization solution to give a final concentration of about 600 $\mathrm{ng} / \mathrm{ml}$. This hybridization solution was reused several times and was stored at $-20^{\circ} \mathrm{C}$ between use. The prehybridized membrane plus $10 \mathrm{ml}$ of hybridization solution with probe were heat-sealed without air in the same bag and submerged. Hybridization and washing conditions were nonstringent. Hybridization was at $60^{\circ} \mathrm{C}$ overnight with shaking $(50 \mathrm{rpm})$, while the final wash was $0.5 \times$ SSC. Hybridized probe DNA was detected using the Genius ${ }^{\mathrm{TM}}$ Nonradioactive DNA Detection Kit, according to manufacturer's instructions. Detection employed an anti-digoxigenin antibody conjugated to alkaline phosphatase. Membrane location of this antibody conjugate was visualized using the substrates 5-bromo-4-chloro-3-indoylphosphate and nitroblue tetrazolium chloride.

Gene libraries were screened for the presence of the H-17 CDase gene by hybridization of the DNA probe to colony lifts of E. coli DH5 $\alpha$ transformants. Colony lifts were performed as recommended by the Genius ${ }^{\mathrm{TM}}$ Nonradioactive DNA Detection Kit, with the following modifications. After Magnagraph nylon membranes were placed on LA agar plates with $1 \mathrm{~mm}$ colonies, the membranes 
were lifted, inverted, placed colony side up on fresh LA plates, and incubated at $37^{\circ} \mathrm{C}$ for $4 \mathrm{~h}$. The master plates were also incubated at $37^{\circ} \mathrm{C}$ until transformant colonies regrew $(5-6 \mathrm{~h})$. The membranes were then removed from the agar and laid, colony side up, on Whatman \#3 filter paper saturated with $10 \%$ SDS for 5 min. The membranes were placed briefly on dry Whatman \#3 filter paper and the process was repeated for \#3 filter paper saturated with $0.5 \mathrm{M} \mathrm{NaOH}, 1.5 \mathrm{M} \mathrm{NaCl}$, followed by \#3 filter paper saturated with $1 \mathrm{M}$ Tris- $\mathrm{HCl}, \mathrm{pH} 8.0,1.5 \mathrm{NaCl}$. The lysed colonies were thoroughly rinsed from the membranes using a squirt bottle containing $5 \times \mathrm{SSC}$, and the membranes were baked at $>80^{\circ} \mathrm{C}$ for $1 \mathrm{~h}$. Hybridization and detection of hybridized probe DNA were essentially as that described for Southern blots, with the exception that hybridization was at $64^{\circ} \mathrm{C}$ in order to decrease colony background.

\section{Construction and Detection of Antibody Probe}

The purified H-17 CDase underwent preparative native PAGE, which yielded a $1 \mathrm{mg}$ sample of enzyme in $0.5 \mathrm{ml} 20 \mathrm{mM}, \mathrm{pH} 7.2$, phosphate buffer, to be used as the antigen. Polyclonal antiserum to the H-17 CDase was prepared by Kelfarms, Alachua, FL, using a $4-5 \mathrm{Kg}$ New Zealand white rabbit. Five days prior to antigen injection a volume of preimmune serum was collected from an ear vein as a negative control. One half $\mathrm{mg}$ of antigen $(250 \mu \mathrm{l})$ was emulsified with $1 \mathrm{ml}$ of Freunds Complete adjuvant, and a total of 5 injections ( 3 intradermal, 1 
subcutaneous, 1 intramuscular) were given. After 30 days, these injections were repeated using $0.5 \mathrm{mg}$ of antigen $(250 \mu \mathrm{l})$ emulsified with $1 \mathrm{ml}$ of Freunds Incomplete adjuvant. Test bleeds were taken from the ear vein at 7 day intervals after each injection series, and the titer followed. An adequate titer was reached after the second series of injections. At that time, the rabbit was anesthetized with a combination of Ketamine and Rompun, and bled out by cardiac puncture. The serum was separated by centrifugation, and stored in $25 \mathrm{ml}$ volumes at $-20^{\circ} \mathrm{C}$.

Serum proteins were precipitated from the polyclonal antisera by the addition of caprylic acid. Two volumes $(10 \mathrm{ml})$ of $60 \mathrm{mM}$ sodium acetate buffer ( $\mathrm{pH} 4.0$ ) were added to $5 \mathrm{ml}$ of serum in a centrifuge tube with stir bar. The $\mathrm{pH}$ was adjusted to 4.8 , and $0.375 \mathrm{ml}(0.75 \mathrm{ml}$ per $10 \mathrm{ml}$ original volume serum) of caprylic acid was added slowly (dropwise) with stirring. After continued stirring for $30 \mathrm{~min}$ at room temperature, the solution was centrifuged at $5,000 \times \mathrm{g}$ for $10 \mathrm{~min}$. The supernatant was decanted, brought to $50 \%$ ammonium sulfate, and stirred overnight at $4^{\circ} \mathrm{C}$. The precipitate was centrifuged at $3,000 \times \mathrm{g}$ for $30 \mathrm{~min}$, dissolved in 2-3 ml of PBS, and dialyzed overnight against $4 \times 1 \mathrm{~L}$ volumes of PBS.

To eliminate low levels of anti-bacterial antibodies, the dialysate was treated with an E. coli DH5 $\alpha$ whole cell acetone powder, prepared as follows. One liter of late $\log$ phase $E$. coli cells was centrifuged at $5,000 \times \mathrm{g}$ for $15 \mathrm{~min}$, and the pellet was resuspended $2 \mathrm{ml}$ of PBS. The cells were chilled on ice, and $8 \mathrm{ml}$ of acetone $\left(-20^{\circ} \mathrm{C}\right)$ was added. The suspension was incubated at $0^{\circ} \mathrm{C}$ for 30 min with 
occasional vigorous mixing, and then centrifuged at $10,000 \mathrm{x} \mathrm{g}$ for $10 \mathrm{~min}$. The pellet was resuspended in fresh acetone $\left(-20^{\circ} \mathrm{C}\right)$, mixed vigorously, allowed to sit at $0^{\circ} \mathrm{C}$ for $10 \mathrm{~min}$, and recentrifuged at $10,000 \mathrm{xg}$ for $10 \mathrm{~min}$. The pellet was airdried on filter paper, broken into a fine powder, and stored at $-20^{\circ} \mathrm{C}$. The acetone powder was added to the antiserum dialysate to a final concentration of $1 \%$, followed by incubation at $4^{\circ} \mathrm{C}$ for $30 \mathrm{~min}$. The suspension was centrifuged at 10,000 $\mathrm{x} \mathrm{g}$ for $10 \mathrm{~min}$, and the purified antiserum supernatant was stored at $-20^{\circ} \mathrm{C}$ until immunological screening and Ochterlony gel diffusion.

Gene libraries were immunologically screened for presence of the $\mathrm{H}-17$ CDase gene product by binding of the purified antiserum to colony lifts of $E$. coli DH5a, E. coli XL1-Blue, and B. subtilis YB886 transformants. Nitrocellulose membranes (Micron Separations, Inc., Westboro, MA) were placed on LA, LAT, or LK agar plates with $1 \mathrm{~mm}$ colonies for $5 \mathrm{~min}$. The membranes were lifted, inverted, placed colony side up on fresh LA, LAT, or LK plates, and incubated at $37^{\circ} \mathrm{C}$ for $5 \mathrm{~h}$. The master plates were also incubated at $37^{\circ} \mathrm{C}$ until transformant colonies regrew $(5-6 \mathrm{~h})$. The membranes were then lifted, exposed to chloroform vapors for $15 \mathrm{~min}$ as previously described, and the colonies lysed overnight in lysis buffer as previously described [75]. The membranes were washed, blocked, and hybridized with primary and secondary antibody as previously described [75], with the following modifications. (a) All washing, blocking, and hybridization volumes were approximately doubled per membrane. (b) The blocking buffer included 5\% 
nonfat dried milk. (c) The purified antiserum, which was the primary antibody, was diluted 1:500 in blocking buffer. (d) The antigen-bound antiserum was detected with an anti-rabbit IgG alkaline phosphatase conjugate (Sigma). This secondary antibody was diluted 1:1,000 in blocking buffer. The antigen-antibody-antibodyalkaline phosphatase complex was visualized using the substrates 5-bromo-4-chloro3-indoylphosphate and nitroblue tetrazolium chloride.

Plasmid Analysis of Probe-Positive E. coli DH5a and B. subtilis YB886 Transformants

All DNA probe-positive and immuno-positive $E$. coli and $B$. subtilis transformants were grown overnight in $5 \mathrm{ml}$ of LA or LK broth, respectively, at $37^{\circ} \mathrm{C}$, with shaking $(100 \mathrm{rpm})$. Plasmid DNA from $1.5 \mathrm{ml}$ of culture was prepared by the alkaline lysis mini-prep procedures as previously described $[10,75]$. B. subtilis YB886 carrying the DNA probe-positive Eco RI fragment in pPL708 was grown overnight in $100 \mathrm{ml}$ of $\mathrm{LK}$ broth at $37^{\circ} \mathrm{C}$, with shaking $(250 \mathrm{rpm})$. A large quantity of plasmid DNA from $100 \mathrm{ml}$ was prepared by the previously described alkaline lysis procedure [10], followed by cesium chloride density gradient centrifugation, as previously described [75]. Ethidium bromide was extracted from the density gradient-purified plasmid with isoamyl alcohol, as previously described [175]. All

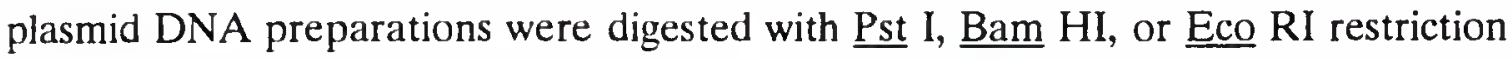
enzymes as previously described. Cloned inserts were analyzed for the presence of 
the H-17 CDase gene by agarose gel electrophoresis and Southern blot hybridization as previously described.

Determination of CDase Activity in Probe-Positive E. coli DH5 $\alpha$ and B. subtilis $\underline{\text { YB886 Transformants }}$

All DNA probe-positive and immuno-positive $E$ coli transformants were streaked onto PRR-LA, MRR-LA, CPR-LA, starch-LA, and PNM-LA agar plates and incubated at $37^{\circ} \mathrm{C}$ for $24-48 \mathrm{~h}$. The plates were then exposed to chloroform vapors as described above. The same transformants were also inoculated into $5 \mathrm{ml}$ of CPR-LA broth and incubated at $37^{\circ} \mathrm{C}$ for $48 \mathrm{~h}$. To determine if $\mathrm{H}-17 \mathrm{CDase}$ activity was intracellular in $E$. coli, the same transformants were each grown at $37^{\circ} \mathrm{C}$ overnight with shaking (100 rpm) in $50 \mathrm{ml}$ of LA broth supplemented with $1 \%$ maltrin M050. Forty $\mathrm{ml}$ of a culture was centrifuged at $5,000 \mathrm{x} \mathrm{g}$ for $10 \mathrm{~min}$, and the pellet was resuspended in $1.5 \mathrm{ml} 20 \mathrm{mM}$ phosphate buffer, $\mathrm{pH} 8.0$, and frozen at $-20^{\circ} \mathrm{C}$. The thawed cells were treated with one-half $\mathrm{ml}$ of lysozyme $(20 \mathrm{mg} / \mathrm{ml})$ in the same buffer, and the suspension was incubated at $37^{\circ} \mathrm{C}$ for $30 \mathrm{~min}$. The suspension was sonicated (Fisher Sonic Dismembrator) at $60 \%$ relative output, for $20 \mathrm{sec}$, with a $1 \mathrm{~cm}$ probe tip, and centrifuged at $12,000 \mathrm{x} \mathrm{g}$ for $15 \mathrm{~min}$. The supernatant (cell-free extract) was assayed for CDase activity at $37^{\circ} \mathrm{C}$ as previously described. 
Preparation of B. subtilis YB886 intracellular cell-free extracts was the same as that described under Ochterlony Gel Diffusion. These cell-free extracts were also used to determine specific activities at $37^{\circ} \mathrm{C}$ for CDase from B. subtilis YB886, and from the same host carrying the probe-positive Eco RI fragment cloned in pPL708. The substrates were $\alpha$ - and B-CD as previously described using the dinitrosalicylic acid method. Protein was determined by the method of Lowry [45].

\section{Ochterlony Gel Diffusion}

Ochterlony gels were $0.9 \%$ purified agar in PBS. Antiserum, purified as above, was undiluted. B. subtilis $25 \mathrm{~S}$, B. caldolyticus $\mathrm{C} 2$, B. subtilis $\mathrm{H}-17$, B. subtilis YB886, and B. subtilis YB886 carrying probe-positive Eco RI fragment in pPL708, were each grown to the same optical density in the previously described starchmaltose based broth. Kanamycin was included at $10 \mu \mathrm{g} / \mathrm{ml}$ for B. subtilis YB886 transformants. A colony from an overnight culture was inoculated into $50 \mathrm{ml}$ and grown at optimal growth temperature $\left(37\right.$ or $\left.60^{\circ} \mathrm{C}\right)$ for $8-10 \mathrm{~h}$, with shaking $(250$ $\mathrm{rpm})$. Cells were centrifuged at $5,000 \mathrm{x}$ g for $10 \mathrm{~min}$, resuspended in $1.5 \mathrm{ml}$ of 20 $\mathrm{mM}, \mathrm{pH} 8.0$, phosphate buffer, and frozen at $-20^{\circ} \mathrm{C}$. Thawed cells were treated with $0.5 \mathrm{ml}$ of lysozyme $(8 \mathrm{mg} / \mathrm{ml})$ in the same buffer, incubated at $37^{\circ} \mathrm{C}$ for $30 \mathrm{~min}$, and centrifuged at $12,000 \times \mathrm{g}$ for $15 \mathrm{~min}$. All supernatants (cell-free extracts) were verified for significant quantities of CDase by performing enzyme assays as previously described. Each cell-free extract was stored at $-20^{\circ} \mathrm{C}$. For gel diffusions, 
each cell-free extract was diluted 1:5 in PBS. Volumes of cell-free extracts and antiserum used in Ochterlony wells were $50 \mu \mathrm{l}$. The wells were chased with $50 \mu \mathrm{l}$ of PBS 2-3 h after the initial sample application. The gels were covered, wrapped in parafilm, and incubated at $37^{\circ} \mathrm{C}$ for $24-48 \mathrm{~h}$.

\section{Expression of Clones in lac ${ }^{\mathrm{q}}$ Host}

The DNA probe-positive Eco RI insert was liberated from pPL708, by digestion of the cesium chloride density gradient-purified plasmid with Eco RI, and the fragment was purified from a preparative agarose gel as described above. The fragment was ligated into the dephosphorylated Eco RI site of pUC18 and the recombinant plasmid was transformed into E. coli XL1-Blue, as previously described. In this host, pUC18 B-galactosidase (lac Z) gene expression is repressed by the $\operatorname{lacI}^{\mathrm{q}}$ gene product, which is encoded on the host's F' episome (plasmid). Therefore, expression of cloned genes that are under control of the pUC18 B-galactosidase promoter is repressed in XL1-Blue. If isopropyl-thiogalactoside (IPTG) is present, it induces $\beta$-galactosidase expression by preventing the ${ }^{2} a \mathrm{I}^{\mathrm{q}}$ protein from binding to the lac $\mathrm{Z}$ operator.

E. coli XL1-Blue transformants were plated onto LAT agar and the plates were incubated at $37^{\circ} \mathrm{C}$ overnight, until colonies were $0.5 \mathrm{~mm}$ in diameter. Colonies that were ampicillin and tetracycline resistant carried the pUC18 vector and the F' episome. The colonies were lifted onto nitrocellulose membranes as previously 
described, and the membranes were incubated colony side up on LAT plates supplemented with $20 \mathrm{mM}$ IPTG, at $37^{\circ} \mathrm{C}$ for $7 \mathrm{~h}$. In order to determine if expression of the $\mathrm{H}-17$ CDase gene is actually repressed in this host, some membranes were incubated on LAT plates without IPTG, under the same conditions. Immunological screening of nitrocellulose membranes, as previously described, was used to detect transformants carrying the Eco RI fragment.

\section{$\underline{\text { Results and Discussion }}$}

The first gene libraries constructed were from the 4-6 $\mathrm{kb}$ and 6-9 $\mathrm{kb}$ fragments isolated from a partial $\underline{\text { Sau }} 3 \mathrm{~A}$ digest of $\mathrm{H}-17$ DNA. Figure 12 illustrates the general strategy for cloning the $\underline{\text { Sau }} 3 \mathrm{~A}$ fragments in pUC18. Two different 4-6 kb libraries were actually made. Each amplified library was repetitively screened on all the substrate agar media (30,000 colonies/screening). Several transformations of E.coli $\mathrm{DH} 5 \alpha$ consistently produced several colonies $(1 / 3,000)$ with enzyme activity on the starch-LA agar, PRR-LA agar, and the MRR-LA agar. It was determined that the starch-hydrolyzing clones (Figure 13) actually produced liquefying $\alpha$-amylase that had no CDase activity. It was also determined that the pullulan-hydrolyzing clones (Figure 14) produced pullulanase that could rapidly cleave amylose but had no CDase activity. Although not shown, several clones on MRR-LA agar plates also produced liquefying $\alpha$-amylase but no CDase. The starch-hydrolyzing clones secreted $\alpha$-amylase extracellularly, but the pullulan- 
Figure 12. General strategy for cloning Sau 3A fragments into the Bam HI site of plasmid vector pUC18. 


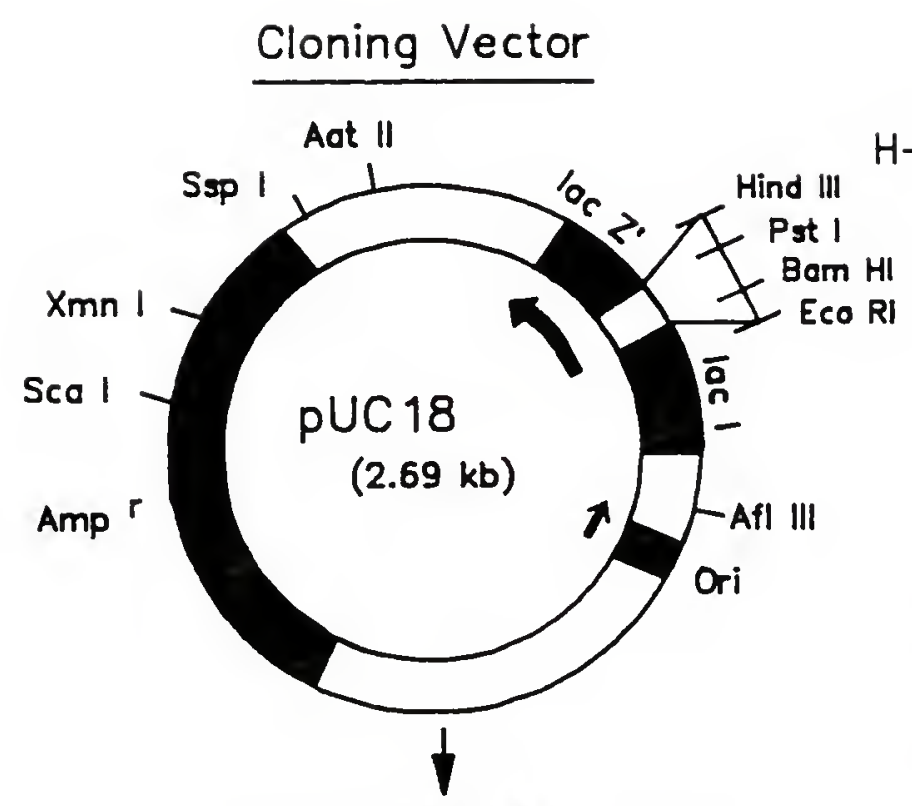

Bam HI digest.

Calf intestinal alkallne phophatose.

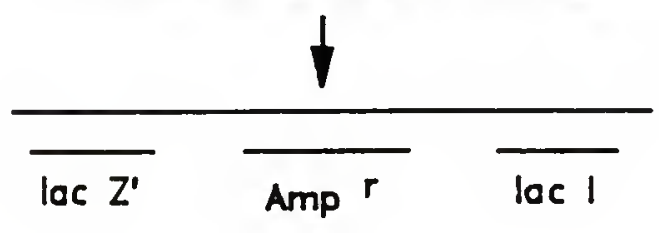

B. subtilis

HTG Transformant

H-17 Chromosomal DNA

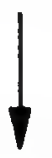

Sou 3A partial digest

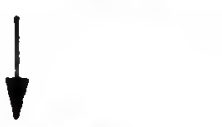

isolate 4-6

and 6-9 $\mathrm{kb}$ fragments

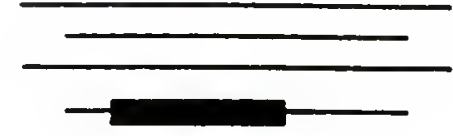

Cdose Gene

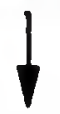

mix vector and fragments 2:1

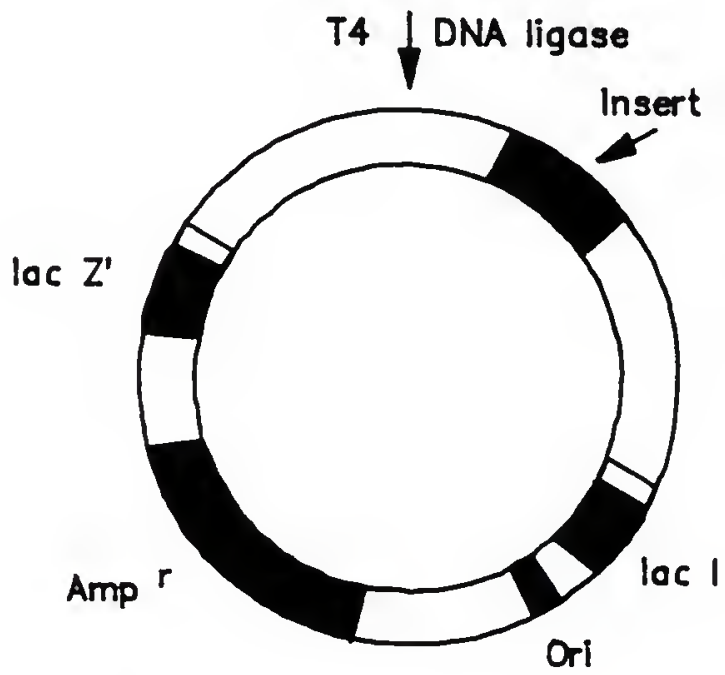

Transform competent $E$.coli DH5- $\alpha$ cells with recombinant plasmids and plate onto LB-ampicillin ogar. 


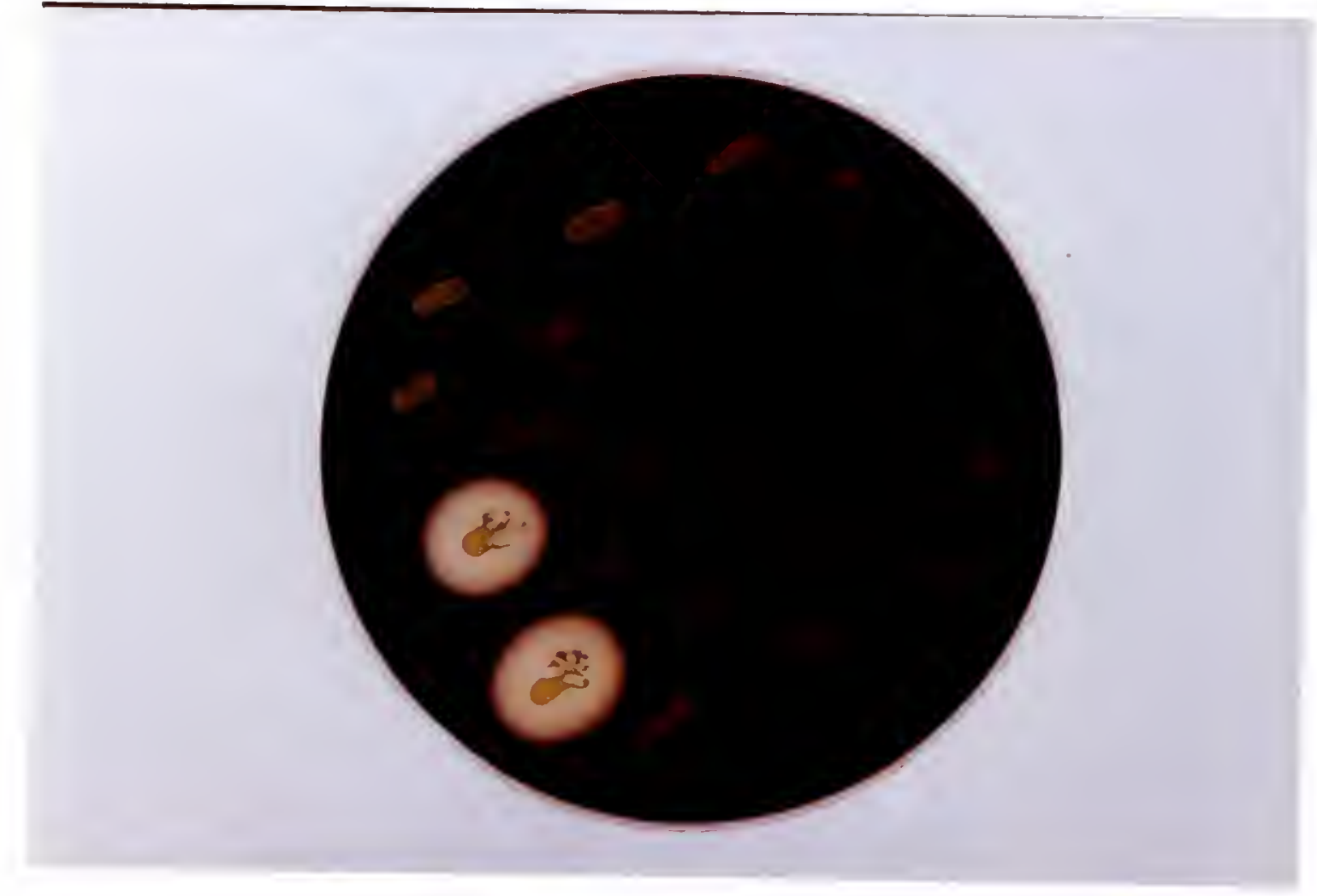

Figure 13. Starch-LA agar plate stained with iodine crystal vapors. Colonies with clear halos are starch-hydrolyzing $E$. coli transformants that carry the cloned $\alpha$-amylase gene. 


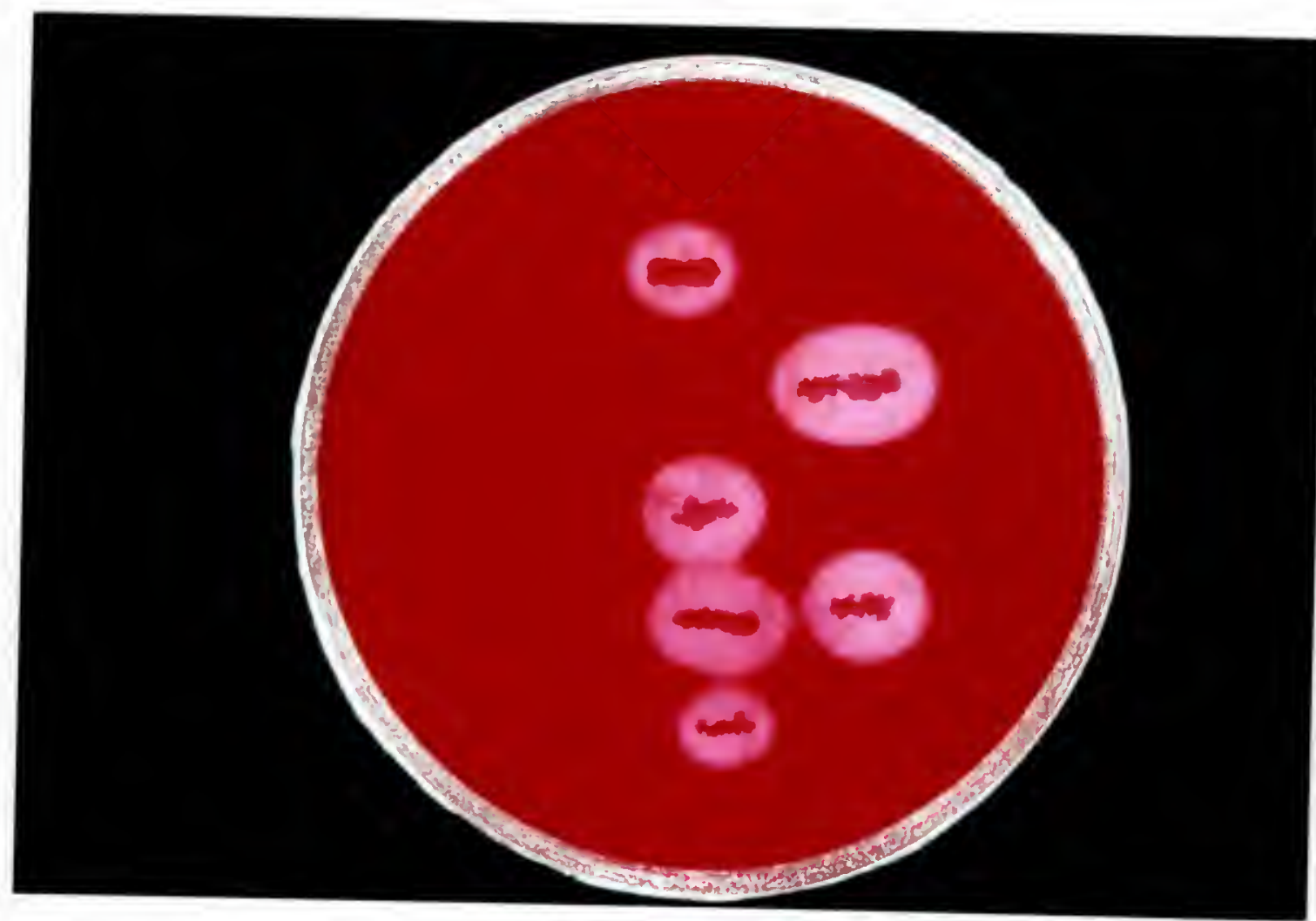

Figure 14. Pullulan-Reactive Red-LA agar plate which had been previously exposed to chloroform vapors. Colonies with clear halos are pullulanhydrolyzing $E$. coli transformants that carry the cloned pullulanase gene. 
hydrolyzing clones required exposure to chloroform vapors to demonstrate pullulanase activity. Unfortunately no CDase clones were isolated after several screenings, partly due to lack of an adequate substrate medium. Ideally, $\alpha$ - or $\beta$ $\mathrm{CD}$ covalently bound to Reactive Red may have been the best screening medium. However, attempts to label $\alpha$ - or $\beta$-CD with Reactive Red were unsuccessful, probably due to the carbohydrate ring structure.

The next approach to isolate the H-17 CDase gene involved construction of a DNA-probe based upon the N-terminal amino acid sequence of the H-17 CDase. Figure 15 shows positive identification of 47 out of 48 residues from the Nterminus, in which most of the amino acids had two or more possible codons. The lower lines in bold show the complementary nucleotide sequences chosen, based upon codon usage of several Bacillus $\alpha$-amylases, and an extensive analysis of B. subtilis codon usage [64]. The oligomer consisted of 42 nucleotides and had a degeneracy of 64 . The $\mathrm{N}$-terminal residue was valine, which implies that a signal sequence was probably cleaved during membrane transport.

The Southern blot in Figure 16 shows positive hybridization of the labelled

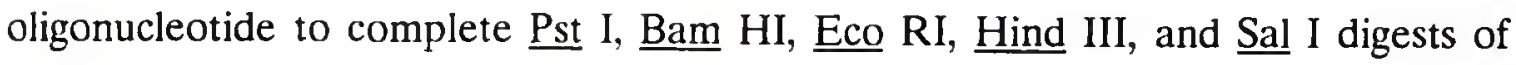
H-17 chromosomal DNA. The probe-positive $\underline{\text { Pst }}$ I, Bam HI, and Eco RI fragments were approximately $8 \mathrm{~kb}, 7 \mathrm{~kb}$, and $3 \mathrm{~kb}$, respectively. Since the H-17 CDase gene was estimated to be $1.5 \mathrm{~kb}$, then there was a fairly good chance that the entire CDase gene was on one or more of these three fragments. 


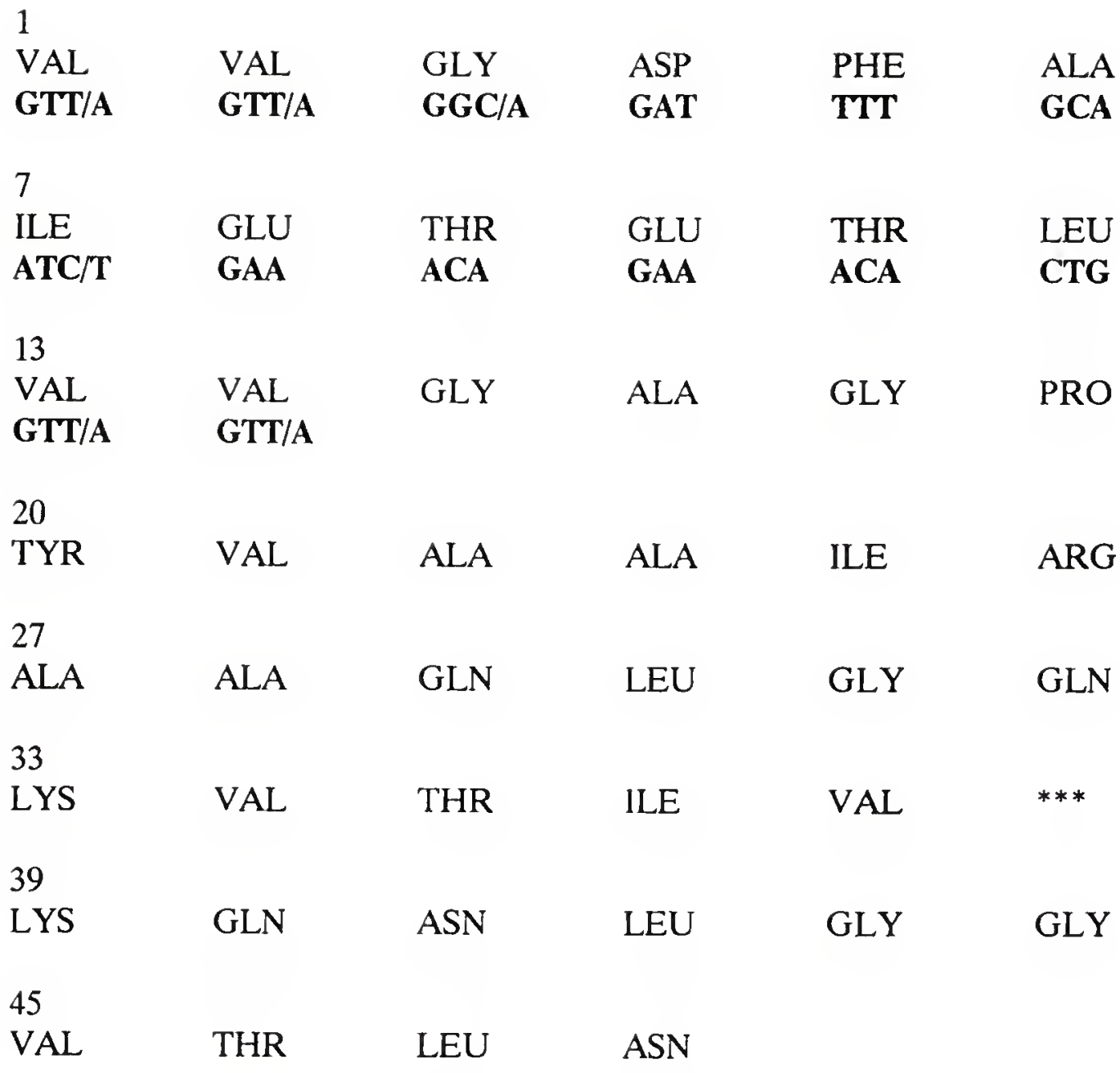

Figure 15. N-terminal amino acid sequence of the $B$. subtilis $\mathrm{H}-17$ thermostable cyclomaltodextrinase. The DNA bases chosen to make the synthetic degenerate oligonucleotide are in bold. The complementary DNA sequence was based on $B$. subtilis codon usage [64]. 


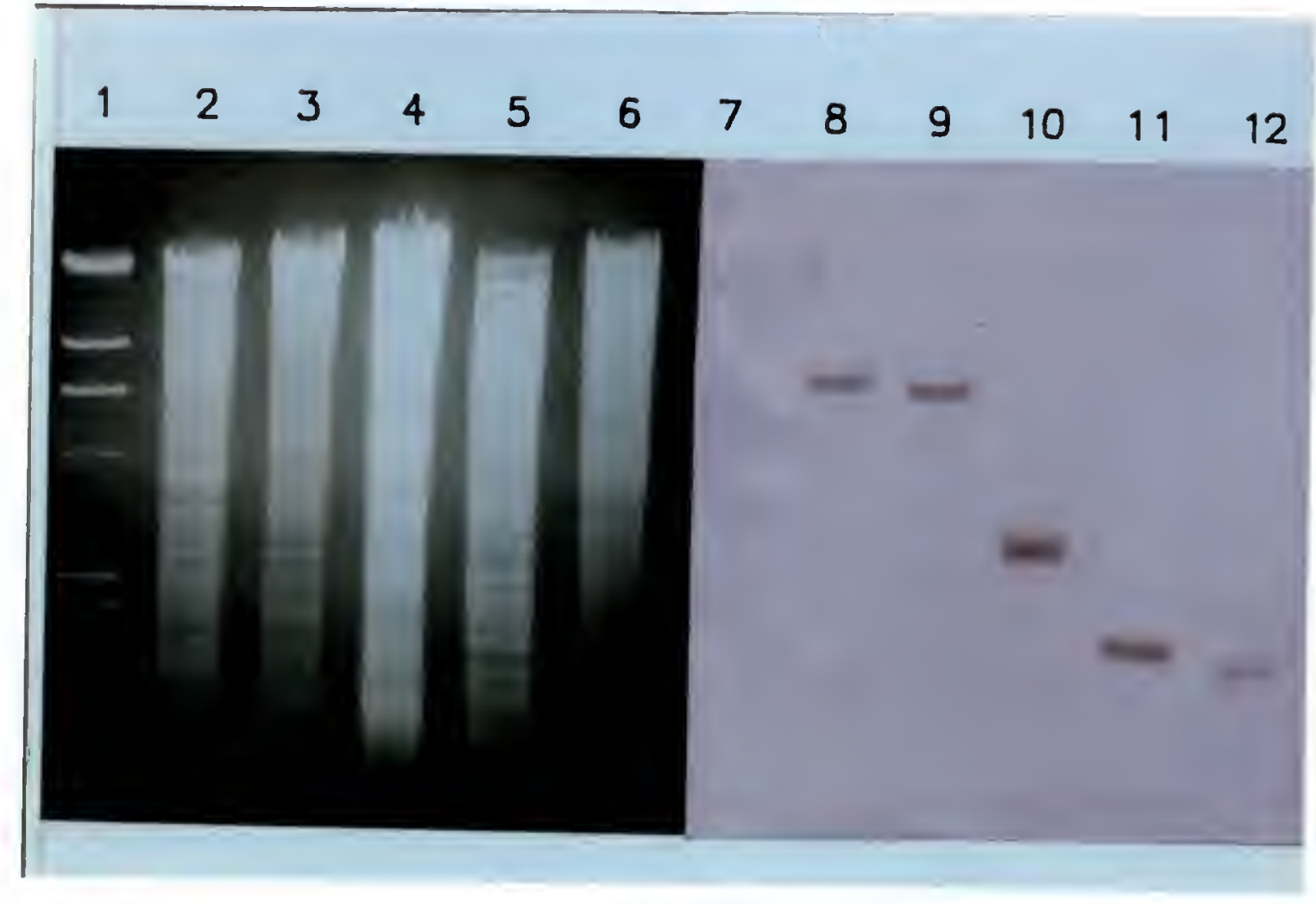

Figure 16. Southern blot hybridization of DNA probe to complete restriction enzyme digests of $B$. subtilis H-17 DNA. Lane 1: Lambda Hind III molecular weight standards $(23.1,9.4,6.6,4.4,2.3$, and $2.0 \mathrm{~kb})$. Lane 2: Pst I digest. Lane 3: Bam HI digest. Lane 4: Eco RI digest.

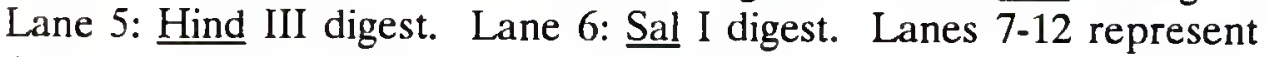
DNA blotted from lanes 1-6, respectively. 
The amplified gene libraries constructed from the Pst I, Bam HI, or Eco RI

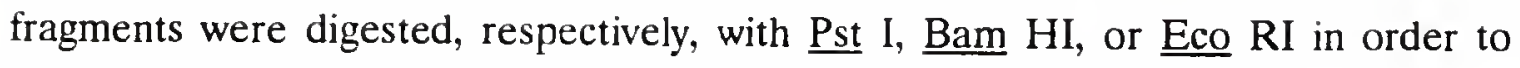
liberate the inserts from pUC18. The Southern blot in Figure 17 shows that the DNA probe hybridized to all three digests, which indicated that the H-17 CDase gene was present in each amplified library. Colony lifts of E. coli DH5 $\alpha$ transformed with either library (Figure 18) showed that the labelled oligonucleotide hybridized to a significant percentage (10-30\%) of transformants. Interestingly, only 10-20\% of the DNA probe-positive transformants regrew on the master plates while the probe-negative transformants rapidly regenerated. The probe-positive transformants were subcultured and colony lifts were verified for DNA probe hybridization. When these probe-positive transformants were streaked onto each type of substrate agar plate or grown in CPR-LA broth, no enzyme activity was detected, with or without plate exposure to chloroform vapors. Cell-free extracts of overnight cultures did not show CDase activity.

Although a part of, if not the entire, H-17 CDase structural gene was present in each library, it was unknown whether the gene was transcribed and translated in E. coli DH5 $\alpha$ to give an active or inactive gene product. Polyclonal antiserum, raised against purified $\mathrm{H}-17 \mathrm{CDase}$, was purified and used to screen $E$. coli DH5 $\alpha$ transformants for expression of the H-17 CDase gene. Colony lifts of

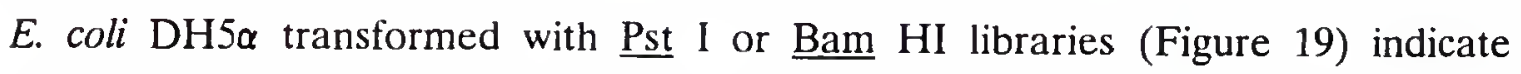
binding of the polyclonal antiserum (primary antibody) to the cloned CDase gene 


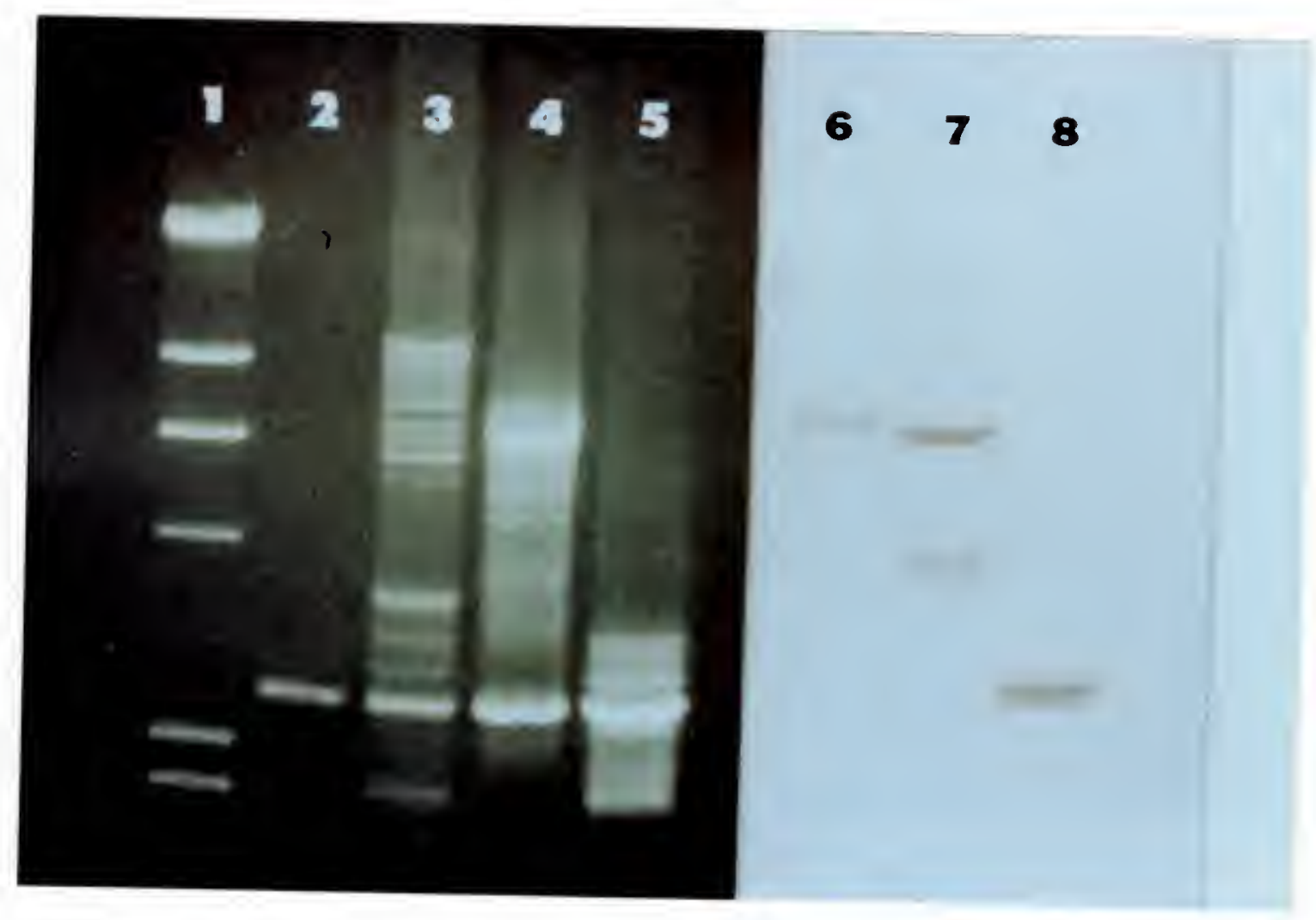

Figure 17. Southern blot hybridization of DNA probe to amplified gene libraries constructed in pUC18. Lane 1: Lambda Hind III standards. Lane 2: pUC18 linearized by an Eco RI digest. Lane 3: Complete Pst I digest of Pst I library. Lane 4: Complete Bam HI digest of Bam HI library. Lane 5: Complete Eco RI digest of Eco RI library. Lanes 6-8 represent DNA blotted from lanes $3-5$, respectively. 


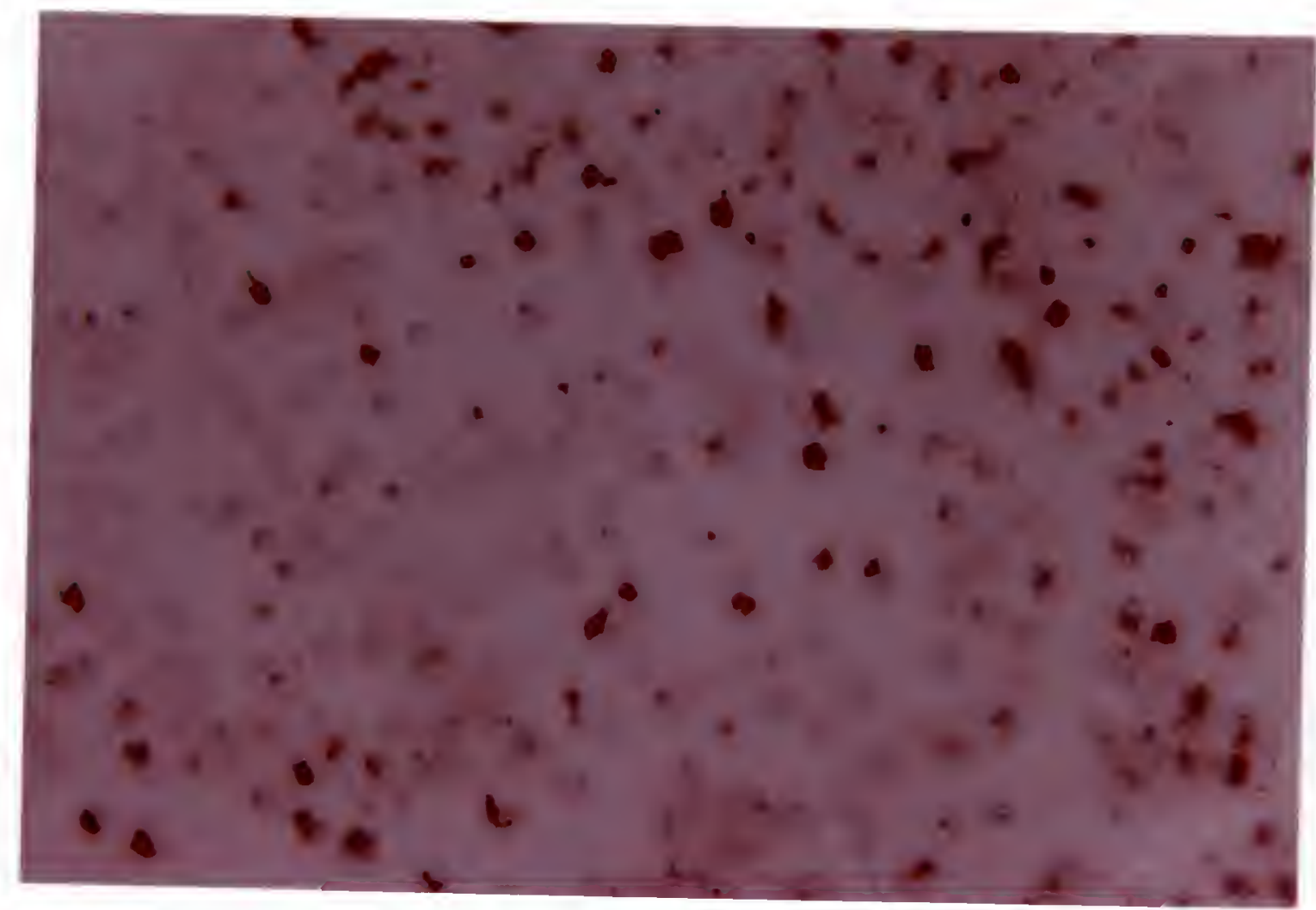

Figure 18. Hybridization of DNA probe to colony lift of E. coli DH5 $\alpha$

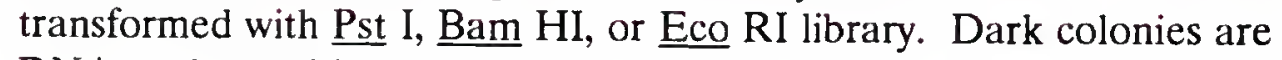
DNA probe-positive. 
Figure 19. Immunologically-screened colony lifts of $E$. coli DH5 $\alpha$ transformed with gene libraries constructed in pUC18. Top membranes: $E$. coli transformed with amplified Pst I library. Bottom membranes: $E$. coli transformed with amplified Bam HI library. 

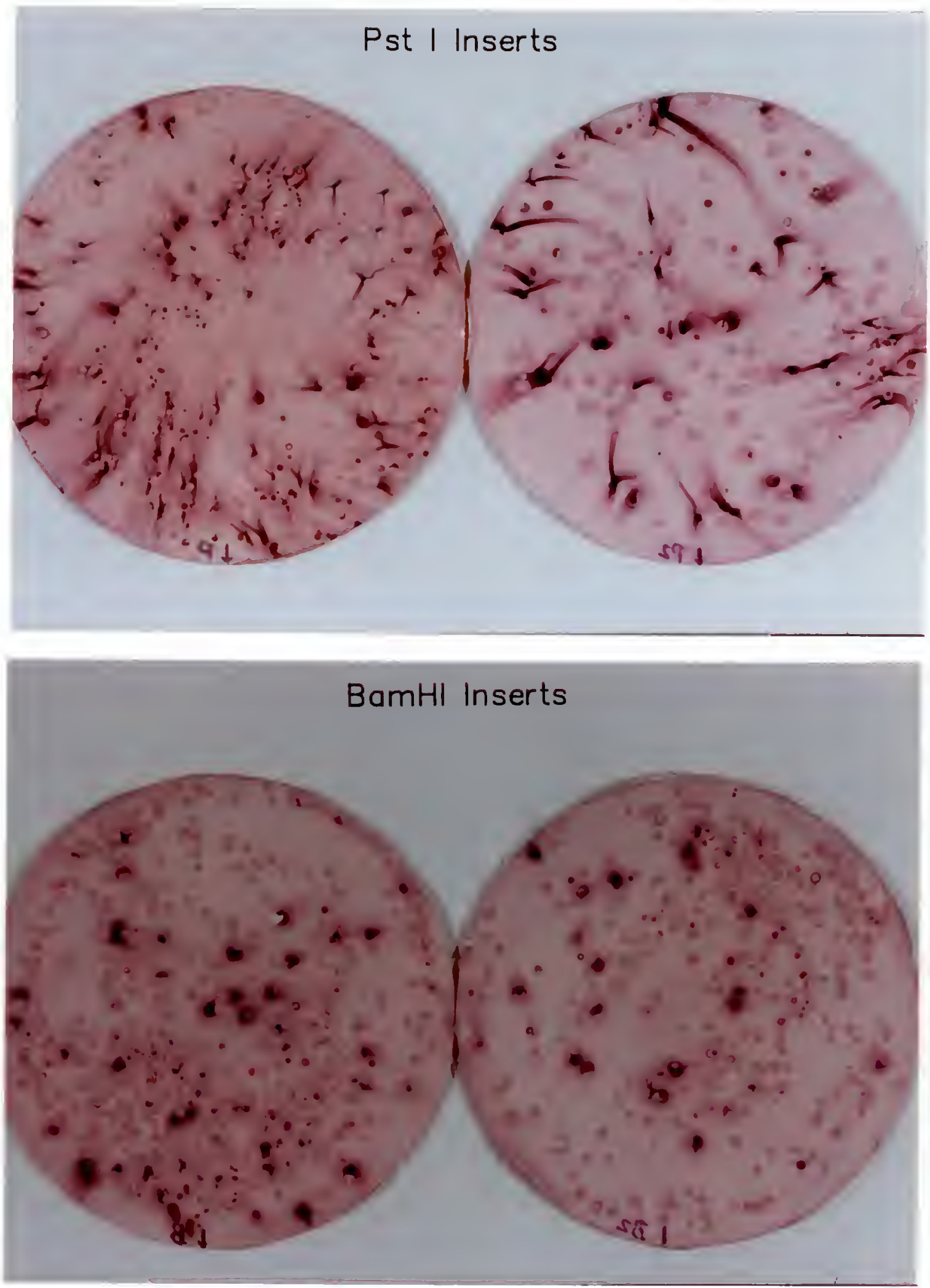
product. Although not shown, the same results were obtained when $E$. coli DH5 $\alpha$ was transformed with the Eco RI library. The frequency of immuno-positive transformants from each library was similar to, or slightly less than, that obtained for DNA probe-positive transformants. The extremely strong immunological signals observed with the colony lifts imply that the H-17 CDase gene is over-expressed. The cloned genes may have been actively transcribed due to the upstream lac $Z$ promoter on pUC18. Once again, only 10-20\% of immuno-positive transformants regrew on master plates. When these immuno-positive transformants were analyzed for CDase activity with each type of substrate media, no enzyme activity could be detected. Cell-free extracts from overnight cultures also produced no CDase activity. Plasmid DNA from several immuno-positive transformants was analyzed by liberating the $\underline{\text { Pst }}$ I, Bam HI, or $\underline{\text { Eco }}$ RI fragment from pUC18 with the respective restriction enzyme. Figure 20 shows agarose gel electrophoresis of

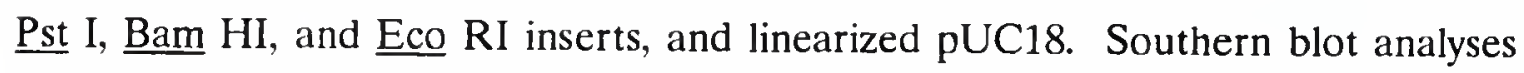
(Figure 21) of these, plus other digests did not show DNA probe hybridization to any of the cloned inserts from immuno-positive transformants. Furthermore, when the immuno-positive transformants carrying $\underline{\text { Pst }} \mathrm{I}$ and $\underline{B a m} \mathrm{HI}$ inserts were subcultured, their colony lifts (Figure 22) demonstrated a gradual loss of immunological detection of the H-17 CDase gene product. Immuno-positive transformants carrying an Eco RI insert did not become immuno-negative upon subculturing, although Southern blots of the inserts were DNA-probe negative. 


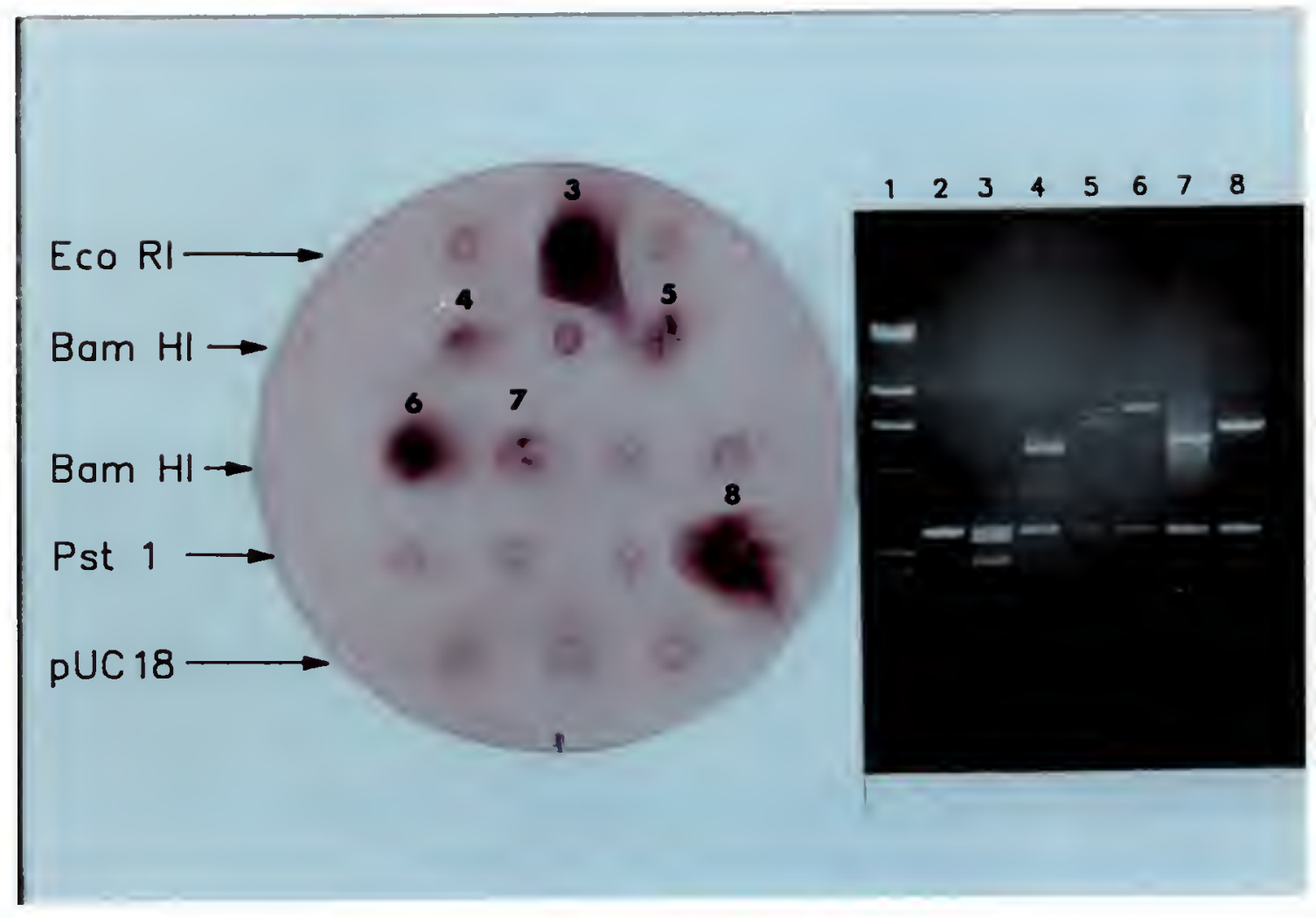

Figure 20. Agarose gel electrophoresis of digested plasmid DNA from several immuno-positive $E$. coli $\mathrm{DH} 5 \alpha$ transformants identified on the corresponding colony lift shown at left. Lane 1: Lambda Hind III standards. Lane 2: pUC18 linearized by an Eco RI digest. Lane 3: Eco RI digest of pUC18 carrying Eco RI inserts. Lanes 4-7: Bam HI

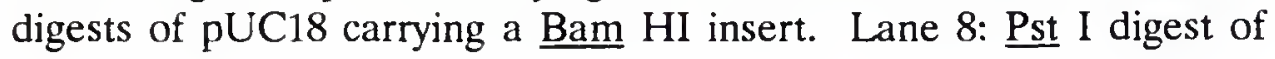
pUC18 carrying a Pst I insert. 
Figure 21. Top: Southern blot analysis of Pst I digested plasmid DNA from several immuno-positive $E$. coli $\mathrm{DH} 5 \alpha$ transformants carrying pUC18 with a Pst I insert. Far right lane is a complete Eco RI digest of $\mathrm{H}$ 17 chromosomal DNA as a positive control.

Bottom: Southern blot analysis of Bam HI digested plasmid DNA from several immuno-positive $E$. coli $\mathrm{DH} 5 \alpha$ transformants carrying pUC18 with a Bam HI insert. Far right lane is a complete Eco RI digest of $\mathrm{H}-17$ chromosomal DNA as a positive control. 


\section{Pst I Inserts}

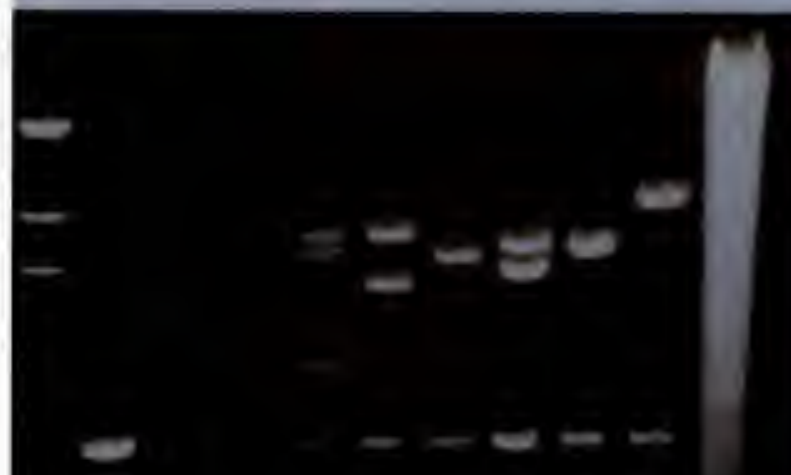

Immunopositive Transformants

BamHI Inserts

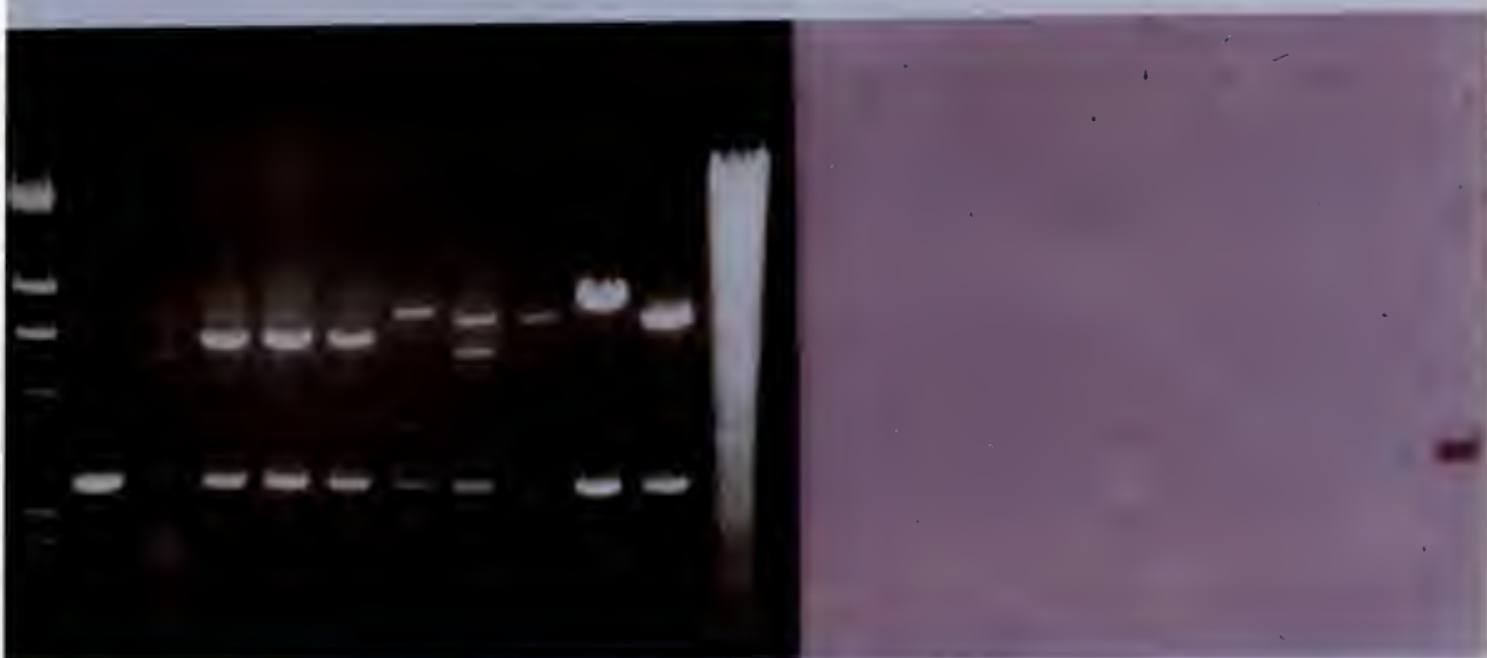

Immunopositive Transformants 


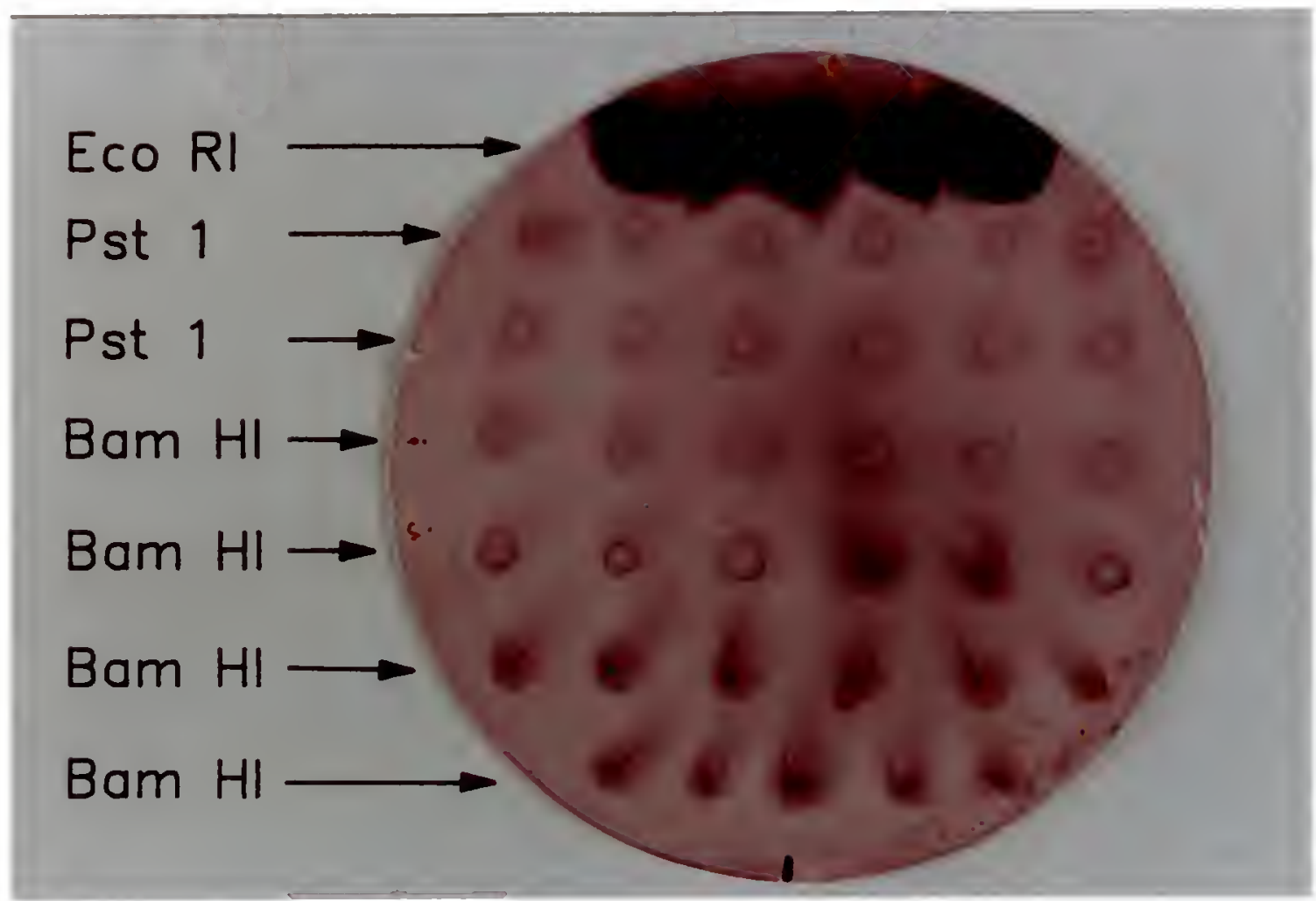

Figure 22. Colony lift of subcultured immuno-positive E. coli DH5 $\alpha$

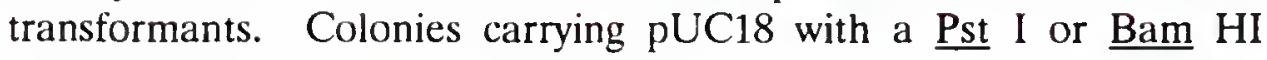
insert show loss of immunological signal. 
It appears that the high copy number of pUC18 plus the strong constitutive promoter activity by the lacZ promoter on pUC18 may have contributed to structural instability of the recombinant plasmids. The gene dosage effect from high level expression of the $\mathrm{H}-17$ CDase gene product probably was detrimental to the host cell, which lead to selection for deletions which remove either the promoter, or all or part of the deleterious gene. In the absence of the toxic CDase gene product, the host cell has a selective advantage which allows it to grow faster than cells without deletions. This was evident in immunologically-screened colony lifts (Figure 19), in which only portions of most colonies, if examined closely, were actually producing the antigen. The same was also evident with the colony lifts in Figure 22. The majority of each colony was immuno-negative because those cells outgrew cells producing a toxic gene product. Transformants carrying Eco RI inserts may have remained immuno-positive because the Eco RI fragment is much smaller than either the $\underline{\text { st }}$ I or Bam HI fragment, and therefore more stably maintained.

The H-17 CDase, although not secreted extracellularly by B. subtilis, is considered to be an exoenzyme, in that it appears to be cell wall-bound or periplasmic in B. subtilis. All the exoenzymes from bacilli that have been cloned and sequenced have a signal peptide or prepeptide at the amino terminal, which must be cleaved to produce a mature enzyme [76]. The general pattern among Bacillus signal peptides involves an $\mathrm{N}$-terminal hydrophilic/basic sequence of about 
10 residues, followed by the hydrophobic core, a stretch of about 20 uncharged residues probably required for membrane translocation. In comparison to $E$. coli, Bacillus signal peptides are longer, usually between 30 and 40 residues, and are more positively-charged at the amino end. When the signal peptide emerges from the ribosome, it interacts with receptor proteins on the inner side of the cell membrane. As the polypeptide chain traverses the membrane, a specific protease cleaves the signal peptide, thereby allowing the enzyme to assume its final native configuration outside the membrane. The cleavage point of the signal'peptide is usually within a sequence of hydrophobic residues, often containing alanine, valine, or glycine $[66,76]$. This is consistent with the first two residues at the $\mathrm{N}$-terminus of the mature $\mathrm{H}-17 \mathrm{CDase}$, which are valine. If the post-translational processing system in E. coli does not recognize the signal sequence of the H-17 CDase, then membrane/cell wall translocation, and/or signal peptide cleavage to give a mature protein may not occur. This would result in high level intracellular accumulation of the CDase gene product, which could be toxic to the host and lead to rapid selection of plasmid deletion derivatives. Consequently, the CDase may have accumulated as a crystalline-like structure (inclusion bodies) in which the enzyme is in a non-native state of little or no biological activity. It is interesting to note that when the $\alpha$-amylase (an exoenzyme) from B. subtilis was cloned in E. coli, it too was deleterious to the host [76]. 
The alternative host-vector system involved B. subtilis YB886 and the plasmid vector pPL708. Gene libraries were constructed from the Pst I and Bam HI DNA probe-positive fragments. However, the transformation frequency for each library was extremely low, probably because the recombinant plasmids were too large due to the long inserts. The transformation frequency of the gene library constructed from DNA probe-positive Eco RI fragments was sufficient to screen colonies for H-17 CDase production. Figure 23 illustrates the general strategy for cloning the Eco RI fragments in pPL708. Since B. subtilis YB886 produces its own CDase, substrate media were not employed to screen transformants. Colony lifts of B. subtilis YB886 transformants were screened immunologically. Unfortunately, the host colonies gave slightly more background since the antiserum was purified with a whole cell acetone powder from E. coli rather than from B. subtilis. However, four colonies in Figure 24 demonstrated a significantly stronger antigenic signal than other colonies. Plasmid DNA from each transformant was digested with Eco RI to liberate the insert from pPL708, and analyzed by agarose gel electrophoresis. Figure 25 shows the Southern blot of each digestion. Although each transformant carried an Eco RI fragment on pPL708, the DNA probe hybridized to only one insert. Plasmid DNA from $100 \mathrm{ml}$ of an overnight culture of the transformant carrying this probe-positive insert was purified by cesium chloride density gradient centrifugation. Southern blot hybridization (Figure 26) of an Eco RI digest of this purified plasmid demonstrates that the plasmid is stably maintained in $B$. subtilis 
Figure 23. General strategy for cloning DNA probe-positive Eco RI fragments into the Eco RI site of plasmid vector pPL708. 


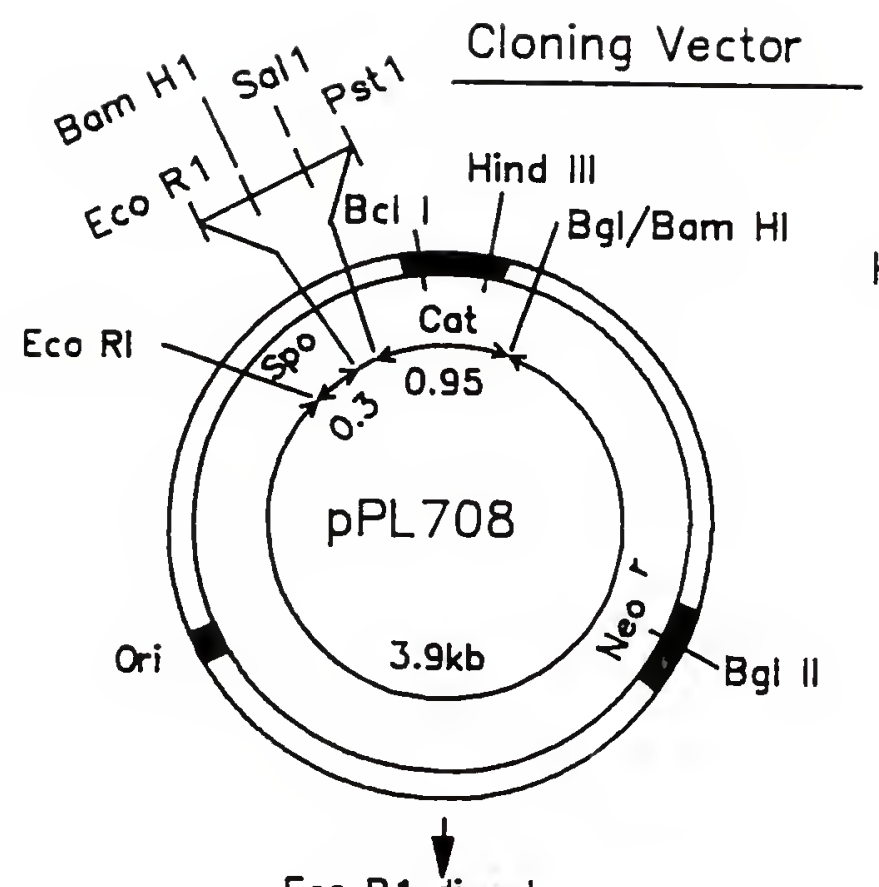

Eco R1 digest

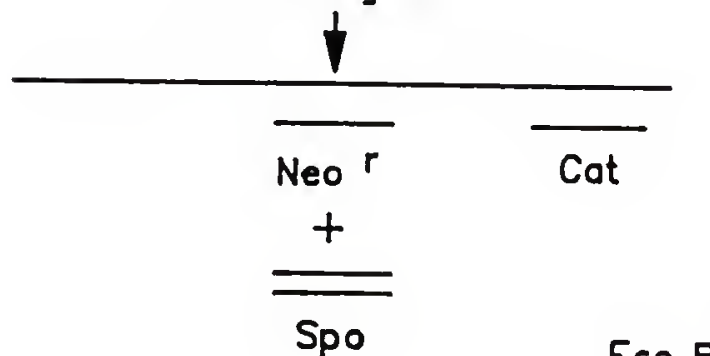

B. subtilis

HTG Transformant

H-17 Chromosomal DNA

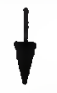

Eco R1 digest

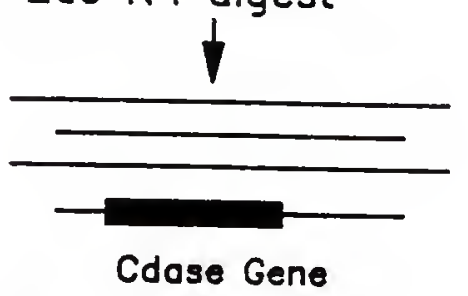

Isolate 2.3-3.2kb Eco R 1 fragments contoining probe positive frogment.

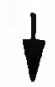

mix vector and

frogments $1: 3$

T4 DNA ligase

Pst 1 Bgl/Bom $\mathrm{H}_{1}$

Probe Positive Insert

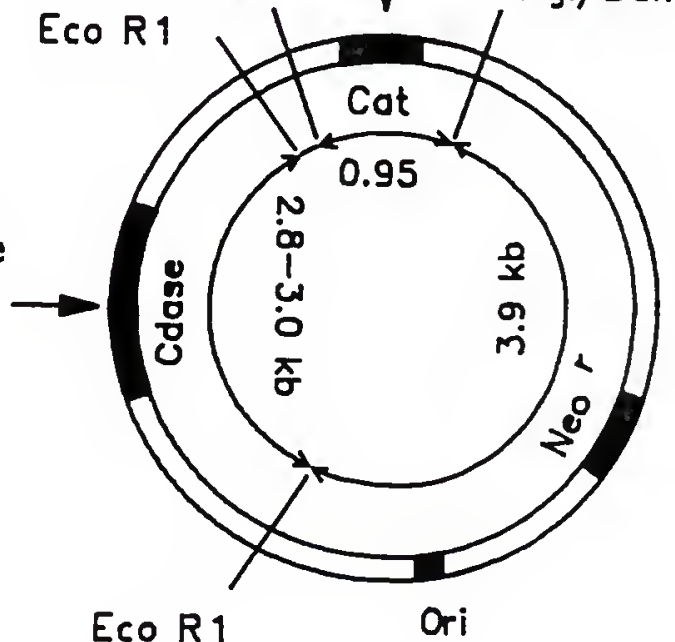

Competent $B$. subtilis YB886 cells transformed with recombinant vector and plated onto LB-kanamycin ogar. 


\section{B. subtilis yB886 Transformants}

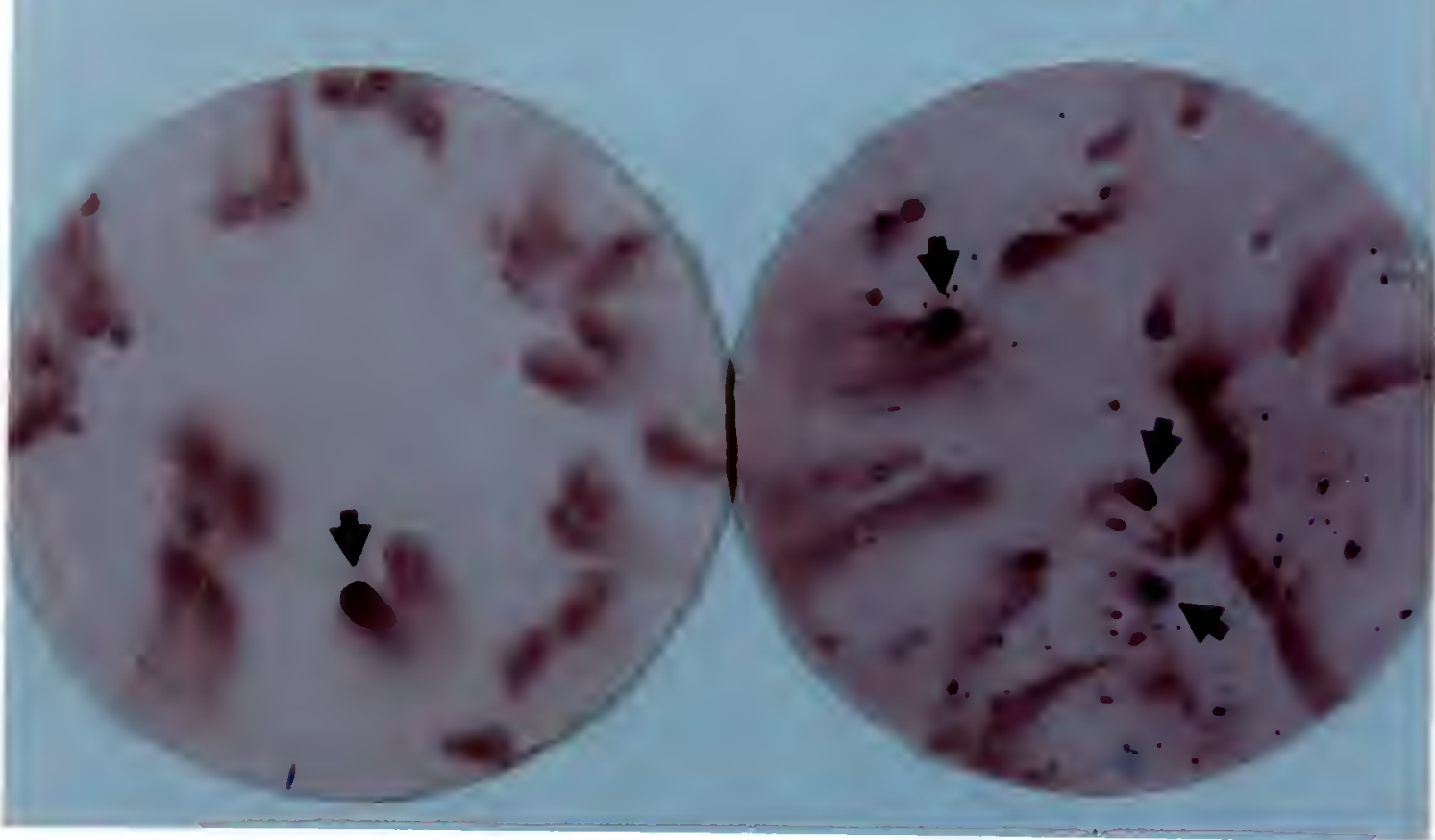

Figure 24. Immunologically-screened colony lifts of B. subtilis YB886 transformed with Eco RI library constructed in pPL708. Arrows indicate four colonies with strong antigenic signal. 


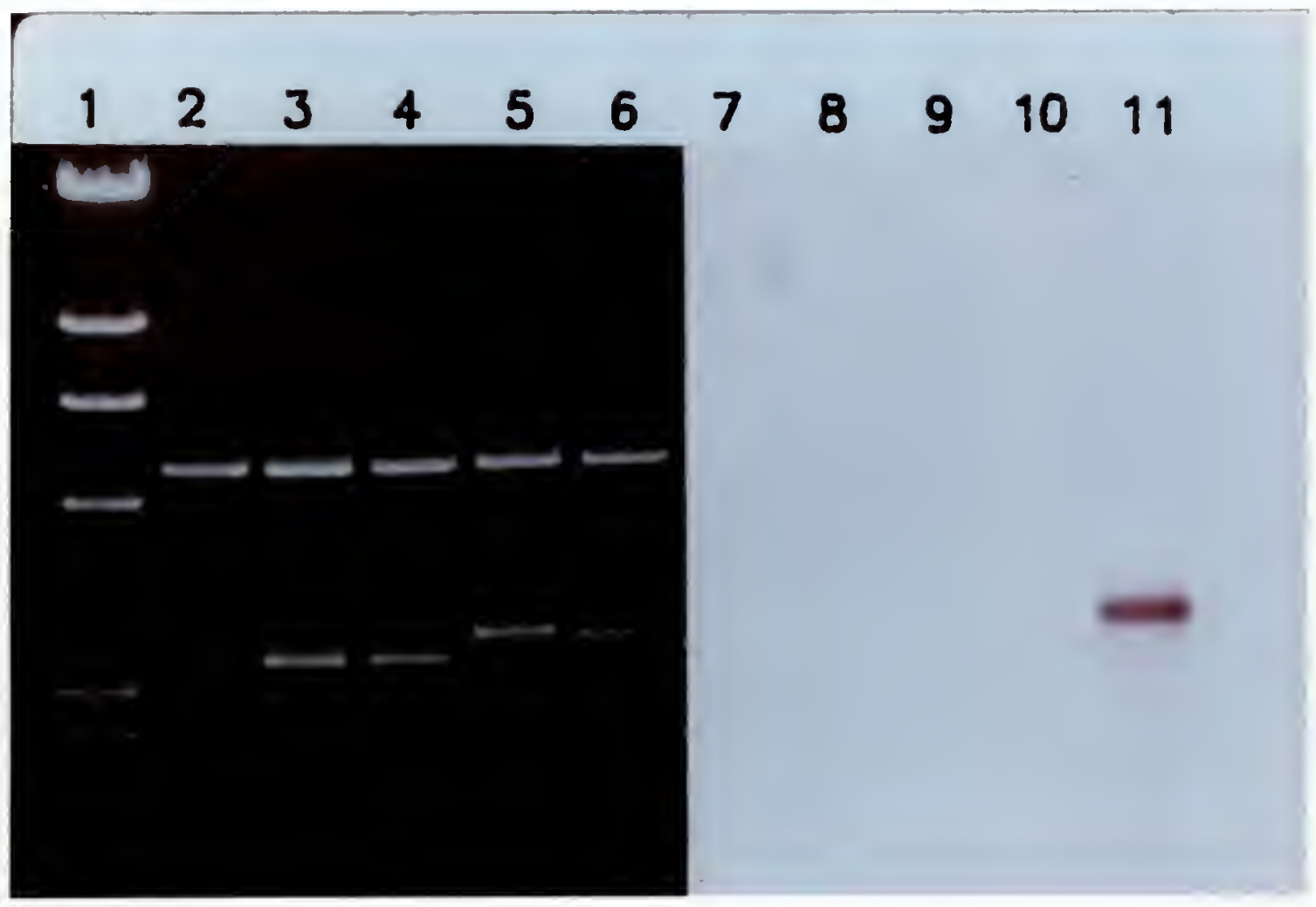

Figure 25. Southern blot hybridization of DNA probe to Eco RI digested plasmid DNA from four $B$. subtilis YB886 immuno-positive transformants. Lane 1: Lambda Hind III standards. Lane 2: pPL708 linearized by Eco RI digestion. Lanes 3-6: Eco RI digests of pPL708 carrying an Eco RI insert. Each lane represents plasmid DNA from one transformant. Lanes 7-11 represent DNA blotted from lanes 2-6, respectively. 


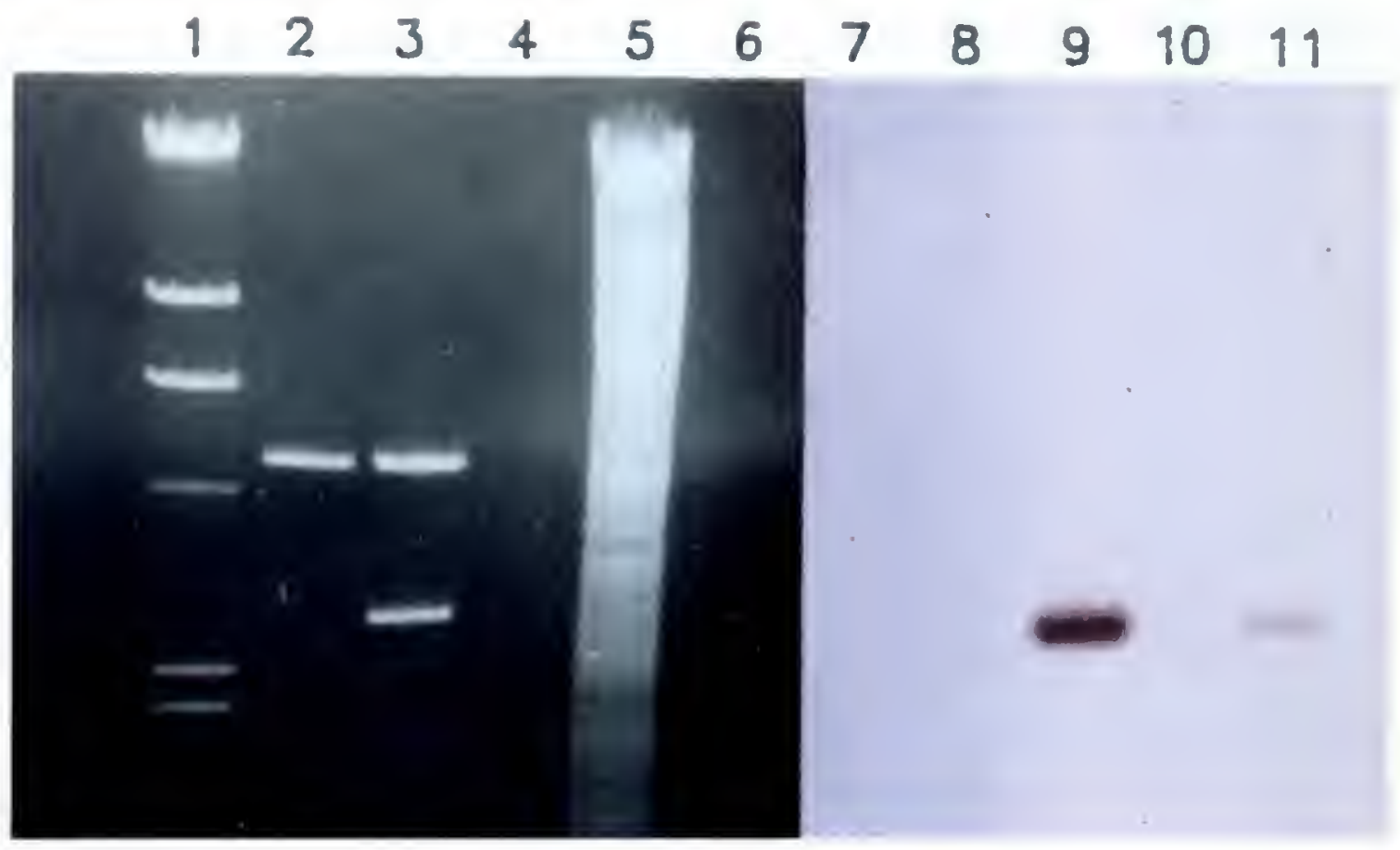

Figure 26. Southern blot hybridization of DNA probe to Eco RI digest of cesium chloride density gradient-purified pPL708 carrying the probe-positive Eco RI insert. Lane 1: Lambda Hind III standards. Lane 2: pPL708 linearized by Eco RI digest. Lane 3: Eco RI digest of density gradient-purified plasmid. Lane 5: Complete Eco RI digest of H-17 chromosomal DNA. Lanes 7-11 represent DNA blotted from lanes $1-5$, respectively. 
YB886 over many generations. Furthermore, the cloned Eco RI fragment is the same size (approximately $3 \mathrm{~kb}$ ) as the DNA-probe positive fragment from an Eco RI chromosomal digest of H-17 DNA (Figure 26).

A drawback in cloning Eco RI fragments into pPL708 is that the plasmid has two Eco RI sites that flank the $0.3 \mathrm{~kb}$ sequence that contains the spo 2 promoter (Figure 11). Consequently, there is a high probability of losing this promoter when ligating Eco RI fragments into pPL708 (Figure 23). The H-17 CDase gene appears to have been cloned with its own promoter on the $3 \mathrm{~kb}$ Eco RI fragment. Table 9 shows the specific activities of cell-free extracts from the B. subtilis host carrying pPL708 with no insert, and pPL708 with the probe-positive $3 \mathrm{~kb} \underline{\text { Eco }} \mathrm{RI}$ insert. Although the specific activities for the clone are slightly greater, preliminary results indicate total CDase activity to be thermolabile. This would seem logical if the $\mathrm{H}-17$ gene is a mesophilic gene that originated in B. subtilis 25S. Expression of the H-17 CDase gene could be enhanced if the gene could be placed downstream from the spo 2 promoter. This would require subcloning the H-17 CDase gene into the Pst I or Bam HI site downstream from the spo 2 promoter, possibly by ligating $\underline{\text { Pst }}$ I or $\underline{\text { Bam }} \mathrm{HI}$ adapters to the ends of the $3 \mathrm{~kb} \underline{\text { Eco }} \mathrm{RI}$ fragment.

The increase in CDase specific activity from the B. subtilis clone also suggests the entire structural $\mathrm{H}-17 \mathrm{CD}$ ase gene is on the probe-positive $3 \mathrm{~kb}$ Eco RI fragment. When this Eco RI fragment was subcloned into pUC18 and transformed 
into $E$. coli XL1-Blue, expression of the gene was not repressed in the absence of IPTG. Figure 27 shows immunologically-screened colony lifts of $E$. coli XL1-Blue in which one membrane was incubated on LAT agar containing IPTG while the other was incubated on LAT agar without IPTG. If expression of the CDase gene was under control of the lacZ promoter, then little or no gene product should be detected in the absence of IPTG. The results indicate that the H-17 CDase gene is efficiently transcribed off its own promoter in $E$. coli, and that the high copy number of pUC18 may be responsible for the detrimental gene dosage effect.

Ochterlony gel diffusion, shown in Figure 28, verified that the $3 \mathrm{~kb}$ Eco RI fragment cloned in pPL708 produced the $\mathrm{H}-17$ CDase gene product. As expected, the purified antiserum cross-reacted with the cell-free extracts from the B. subtilis YB886 clone and from B. subtilis $\mathrm{H}-17$, but not with that from B. subtilis YB886 carrying pPL708 with no insert. Surprisingly, the antiserum also cross-reacted with the cell-free extract from $B$. caldolyticus $C 2$, but not with that of $B$. subtilis $25 \mathrm{~S}$. One explanation may be that the $25 \mathrm{~S}$ CDase acquired sufficient alterations in antigenic determinants in its transition to a thermostable form in B. subtilis $\mathrm{H}-17$. Consequently, the enzyme resembled the $\mathrm{C} 2$ CDase in its antigenic determinants. Although Figure 28 indicates cross-reactivity of the polyclonal antiserum to the $\mathrm{C} 2$ and cloned enzyme, distinct lines of precipitation indicated non-identity between these two enzymes. This would indicate that the two enzymes do indeed share common antigenic determinants, but are non-identical. A second explanation may 
be that the $\mathrm{C} 2$ CDase gene was actually transferred to $B$. subtilis $25 \mathrm{~S}$ during the transformation to thermophily. In this case, the $\mathrm{H}-17 \mathrm{CDase}$ is the product of the C2 CDase gene in $B$. subtilis $\mathrm{H}-17$, and there could actually be two CDase genes in this HTG transformant. To further clarify this situation, the CDase gene on the cloned Eco RI fragment will be labelled, and then used to probe Southern blots of genomic DNA digests from B. subtilis $25 \mathrm{~S}$ and B. caldolyticus C2. This will hopefully identify the origin of the H-17 CDase gene, and perhaps clarify why the $\mathrm{H}-17$ CDase is thermostable. 
Table 9. Comparison of cyclomatodextrinase activity between $B$. subtilis YB886 carrying pPL708 with no insert, and $B$. subtilis YB886 carrying PPL708 with probe-positive $3 \mathrm{~kb}$ Eco RI fragment.

Specific Activity

( $\mu$ moles reducing groups $/ \mathrm{min} / \mathrm{mg}$ protein)

Cell Free Extract

$\underline{\alpha \text {-Cyclodextrin }}$

$\underline{\text { B-Cyclodextrin }}$

B. subtilis YB886

0.61

0.64

B. subtilis YB886 with cloned Eco RI fragment

0.98

0.93 


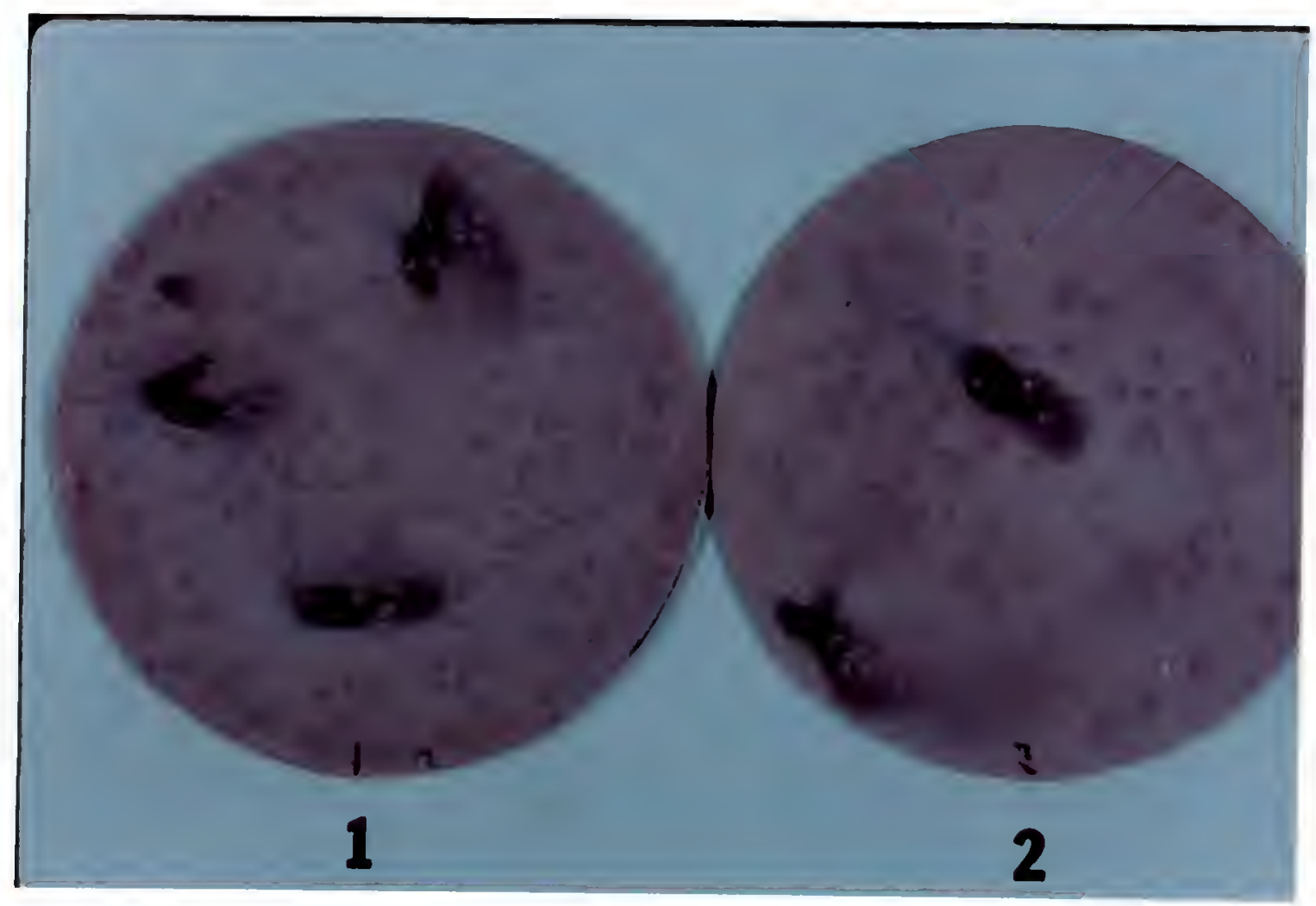

Figure 27. Immunologically-screened colony lifts of $E$. coli XL1-Blue transformed with pUC18 carrying the DNA probe-positive Eco RI fragment purified from pPL708. Left membrane (1) was incubated at $37^{\circ} \mathrm{C}$ for $7 \mathrm{~h}$ on LAT agar supplemented with $20 \mathrm{mM}$ IPTG, while right membrane (2) was incubated under identical conditions without IPTG. 


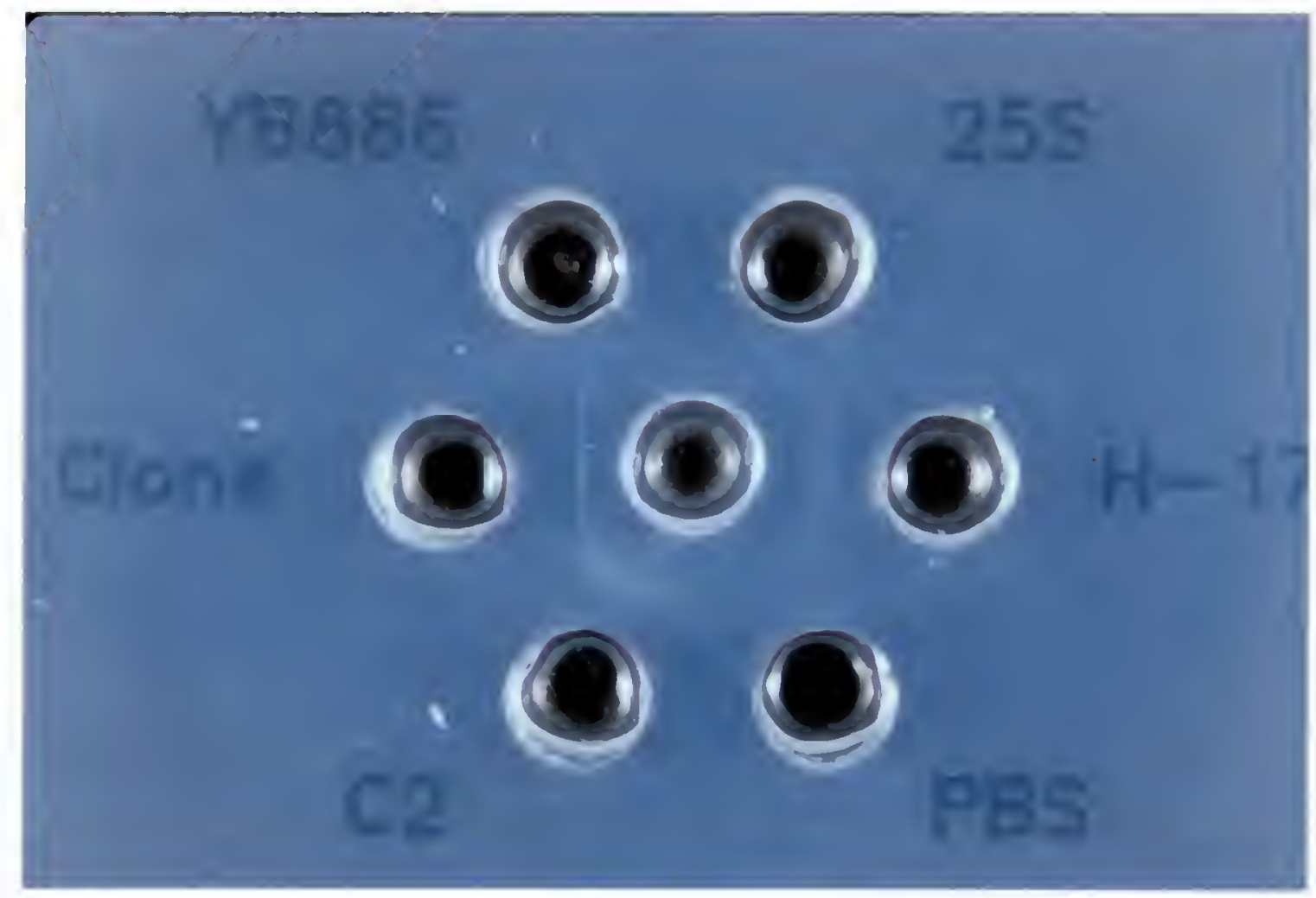

Figure 28. Ochterlony gel diffusion of purified rabbit polyclonal antisera against late log phase cell-free extracts. Center well: Purified antisera. Outer wells (clockwise from lower left): Cell-free extract from B. caldolyticus $\mathrm{C} 2$; B. subtilis YB886 clone carrying pPL708 with DNA probe-positive Eco RI insert; $B$. subtilis YB886 carrying pPL708 with no insert; B. subtilis 25S; B. subtilis H-17; Phosphate-buffered saline. 


\section{CHAPTER 6 \\ SUMMARY AND CONCLUSIONS}

The CDases produced by $B$. subtilis $25 \mathrm{~S}, B$. caldolyticus $C 2$, and $B$. subtilis H-17 are all highly related to each other both biochemically and biophysically. They each share common or very similar properties such as $\mathrm{M}_{\mathrm{r}}$, subunit structure, $\mathrm{pH}$ optimum, isoelectric point, cation inhibition, and substrate specificity and affinity. All behave as low active. exo-acting, maltogenic enzymes against starch polymers, but show a highly-active endo- and exo-type attack on cyclodextrins and maltodextrins. These characteristics, which closely resemble properties of similar enzymes from other Bacillus species, support the theory that thermophilic, mesophilic, and psychrophilic bacteria from the genus Bacillus evolved from common ancestors $[44,114,115]$. Despite these similarities, there is however, a significant difference between the $25 \mathrm{~S}, \mathrm{C} 2$, and $\mathrm{H}-17 \mathrm{CD}$ ase thermostability. This difference is probably attributable to alterations in the hydrophobic amino acid content between each enzyme, and confirms previous results for the histidinol dehydrogenase enzymes from $25 \mathrm{~S}, \mathrm{C} 2$ and the HTG transformants [41].

The results from this study support the previously proposed hypothesis that thermostable proteins produced by the HTG transformants are the result of either specific mistranscription or mistranslation of the B. subtilis 25S genes [39]. There 
are, however, several important and as yet unanswered questions. First, how does the presence of a reducing agent or chelating agent produce a difference in thermostability among the CDases? Second, are the requirements of these extrinsic factors for thermostability also a reflection of specific amino acid changes due to mistranscription or mistranslation of the 25S CDase gene? Third, are the requirements for 2-Me or EDTA not directly due to mistranscription or mistranslation, but are the consequence of an altered three-dimensional conformation due to an increase in hydrophobic residues? Fourth, why does 2-Me confer a greater thermostability for the H-17 CDase, while EDTA confers a greater thermostability for the $\mathrm{C} 2 \mathrm{CDase}$ ?

There appears to be a complex combination of different molecular mechanisms which produces an interactive, cooperative network of intramolecular interactions that are responsible for the differences in thermostability among the three enzymes. Since the CDases are not extracellular enzymes, perhaps 2-Me and EDTA are not required for thermostability, in vivo! An intracellular environment may protect these enzymes from thermostability inhibitors that are encountered in vitro studies. Conversely, thermostability per se may be attributable to a more simple mechanism, for example, a subtle change in proline content. Although supporting the previous hypothesis, the biochemical results alone provide no definitive insights into how proteins were made thermostable by the HTG transformants. Future research would involve both amino acid sequencing of the 
CDases and determination of the amino acid sequence derived from the nucleotide sequence of the CDase gene. This would determine which amino acid substitutions resulted due to either mistranscription or mistranslation.

While the $\mathrm{H}-17$ CDase was cloned in pUC18, its gene product was expressed in $E$. coli in an inactive form and was toxic to the cell. The problem of structural instability of the recombinant plasmid in E. coli was resolved by cloning the gene in pPL708 and expressing it in B. subtilis. By subcloning the gene into a Bacillus expression vector, the levels of enzyme could be greatly increased, as long as toxicity to the host is avoided. Preliminary results indicated the cloned H-17 CDase to be thermolabile in B. subtilis. Perhaps the cloned gene may also need to be expressed in a thermophilic Bacillus host in order to obtain a thermostable enzyme that still has industrial potential. Thus far, all genes encoding for thermostable enzymes that have been cloned and expressed in a mesophilic host, have produced an enzyme that retained its thermostable properties. Theoretically, the $\mathrm{H}-17 \mathrm{CDase}$ gene originated from a mesophile. This may explain the expected discrepancy in which the $\mathrm{H}-17$ CDase becomes thermolabile when transferred back to a mesophilic host. Current research involves determining the origin of the H-17 CDase gene. Southern blot analysis of genomic DNA from the parents, B. subtilis 25S and $B$. caldolyticus $\mathrm{C} 2$ may clarify the events that occurred in the transformation to thermophily. 
Although the H-17 CDase may have limited industrial applications, the results show that protein thermostability may be achieved via a unique, alternative approach, that is, by conversion of the entire cell of a mesophile into that of a thermophile. Therefore, the generation of HTG transformants from GRAS status mesophiles may be useful for the synthesis of thermostable enzymes with commercial value. One potential application of the $\mathrm{H}-17$ CDase is the industrial production of high maltose syrups. The enzyme's neutral $\mathrm{pH}$ optimum would allow it to be employed immediately prior to starch liquefaction by highly thermostable B. licheniformis $\alpha$-amylase, without any change in $\mathrm{pH}$. However, a drop in temperature would be required. Alternatively, the enzyme could be used simultaneously with a neutrophilic, thermostable $\alpha$-amylase with a lower temperature optimum. A possible drawback may be the necessary addition of a foodsafe reducing agent in order for the CDase to maintain thermostability. However, the H-17 CDase has been characterized for thermostability under relatively dilute substrate concentrations (less than $5 \% \mathrm{w} / \mathrm{v}$ ). Commercial starch conversion begins with $35-37 \%$ starch dry solids, a very high concentration. High levels of substrates tend to increase thermostability by stabilizing enzyme conformation and protecting the catalytic site [9]. The H-17 CDase has not been thermally-characterized under conditions of extremely high substrate concentrations. Future research which focusses on this aspect, may show it unnecessary to add a foodsafe reducing agent in an industrial condition, in which substrate concentrations are extremely high. 


\section{REFERENCES}

1. Alber T, Matthews BW (1987) The use of x-ray crystallography to determine the relationship between the structure and stability of mutants of phage $\mathrm{T} 4$ lysozyme. In; Oxender DL, Fox CF (eds) Protein Engineering. New York: Alan R. Liss, Inc., pp 289-297

2. Amelunxen RE, Murdock AL (1978) Mechanisms of thermophily. Crit Rev Microbiol 6:343-384

3. Argos P, Rossmann MG, Grau UM, Zuber H, Frank G, Tratschin JD (1979) Thermal stability and protein structure. Biochem 18:5698-5703

4. Aunstrup K (1978) Enzymes of industrial interest; traditional products. Ann Rep Ferment Proc 2:125-154

5. Ausubel FM, Brent R, Kingston RE, Moore DD, Seidman JG, Smith JA, Struhl K (1989) Current protocols in molecular biology. New York: WileyInterscience, pp 3.0.1-3.1.17

6. Bender H (1981) A bacterial glucoamylase degrading cyclodextrins. Eur J Biochem 115:287-291

7. Bernfeld B (1955) Amylases, $\alpha$ and B. In: Colowick S, Kaplan N (eds) Methods in enzymology, vol 1. New York: Academic Press, pp 149-158

8. Bounias M (1980) N-(1-napthyl)ethylenediamine dihydrochloride as a new reagent for nanomole quantification of sugars on thin-layer plates by a mathematical calibration process. Anal Biochem 106:291-295 
9. Boyce COL (1986) Novo's handbook of practical biotechnology. Bagsvaerd, Denmark: Novo Industri A/S, pp 35-41, 70-76, 101-103

10. Bron S (1990) Plasmids. In: Harwood CR, Cutting SM (eds) Molecular biological methods for Bacillus. New York: Wiley-Interscience, pp 139-149, $545-550$

11. Castenholz RW (1979) Evolution and ecology of thermophilic microorganisms. In: Shilo $M$ (ed) Strategies of microbial life in extreme environments. Dahlem Konferenzen. Berlin, 373-392

12. Chilton MD, McCarthy BJ (1969) Genetic and base sequence homologies in bacilli. Genetics 62:697-710

13. Creaser EH, Hughes GJ, Dhawale M, Kolber M, Lindsay JA (1977) Histidinoldehydrogenase: A model of evolutionary strategies. In: Matsubara $\mathrm{H}$, Yamanaka $\mathrm{T}$ (ed) Evolution of protein molecules. Tokyo: Japanese Science Society Press, pp 161-173

14. Debabov VG (1982) The industrial use of bacilli. In: Dubnau D (ed) The molecular biology of the bacilli. New York: Academic Press, pp 331-370

15. DePinto JA, Campbell LL (1968) Purification and properties of the cyclodextrinase of Bacillus macerans. Biochemistry 7:121-125

16. DePinto JA, Campbell LL (1968) Pattern and action of the amylase and the cyclodextrinase of Bacillus macerans. Arch Biochem Biophys 125:253-258

17. Droffner ML, Yamamoto N (1985) Isolation of thermophilic mutants of Bacillus subtilis and Bacillus pumilus and transformation of the thermophilic trait to mesophilic strains. J Gen Microbiol 131:2789-2794 
18. Dubnau D, Smith I, Morell P, Marmur J (1965) Gene conservation in Bacillus species, I. Conserved genetic and nucleic acid base sequence homologies. Proc Natl Acad Sci (USA) 54:491-498

19. Ferrell J, Campbell LL (1969) Thermophilic bacteria and bacteriophages. Adv Microbial Physiol 3:83-109

20. Fogarty WM (1983) Microbial amylases. In: Fogarty WM (ed) Microbial enzymes and biotechnology. London, New York: Applied Science Publishers, pp 1-92

21. Fogarty WM, Griffin PJ, Joyce AM (1974) Enzymes of Bacillus species - part 1. Process Biochem Jul/Aug:11-24

22. Friedman SM, Mojica T (1978) Transformants of Bacillus subtilis capable of growth at elevated temperatures. In: Friedman SM (ed) Biochemistry of Thermophily. New York: Academic Press, pp 117-126

23. Friedman SM, Yamamoto N (1990) Properties of cell-free extracts from Bacillus subtilis and its thermophilic mutant. Curr Microbiol 21:211-215

24. Fullbrook PD (1984) The enzymic production of glucose syrups. In: Dziedzic SZ, Kearsley MW (eds) Glucose syrups: Science and technology. London, New York: Elsevier Applied Science Publishers, pp 65-115

25. Hediger MA, Frank G, Zuber H (1986) The primary structure of the mesophilic lactate dehydrogenase from Bacillus subtilis. Biol Chem HoppeSeyler 367:891-903

26. Ihara H, Sasaki T, Tsuboi A, Yamagata H, Tsukagoshi N, Ukaka S (1985) Complete nucleotide sequence of a thermophilic $\alpha$-amylase gene: homology between prokaryotic and eukaryotic $\alpha$-amylases at the active sites. J Biochem 98:95-103 
27. Jackson D (1981) Cost reductions in food processing using biotechnology. In: Harlander S, Labuza T (eds) Biotechnology in food processing. Park Ridge, NJ: Noyes Publications

28. Jaenicke R (1981) Enzymes under extremes of physical conditions. Ann Rev Biophys Bioeng 10:37-47

29. Kato K, Sugimoto T, Amemura A, Harada T (1975) A Pseudomonas intracellular amylase with high activity on maltodextrins and cyclodextrins. Biochim Biophys Acta 391:96-108

30. Kitahata S, Okada S (1985) Hydrolytic action on various maltosides by an enzyme from Bacillus coagulans. Carbohydr Res 137:217-225

31. Kitahata S, Taniguchi M, Beltran S D, Sugimoto T, Okada, S (1983) Purification and some properties of cyclodextrinase from Bacillus coagulans. Agric Biol Chem 47:1441-1447

32. Klibanov AM (1983) Stabilization of enzymes against thermal inactivation. Adv Appl Microbiol 29:1-28

33. Kuriki T, Okada S, Imanaka T (1988) New type of pullulanase from Bacillus stearothermophilus and molecular cloning and expression of the gene in Bacillus subtilis. J Bacteriol 170:1554-1559

34. Kuroda S, Tanizawa K, Sakamoto Y, Tanaka H, Soda K (1990) Alanine dehydrogenases from two Bacillus species with distinct thermostabilities: molecular cloning, DNA and protein sequence determination, and structural comparison with other $\mathrm{NAD}(\mathrm{P})^{+}$-dependent dehydrogenases. Biochem 29:1009-1015

35. Laemmli UK (1970) Cleavage of structural proteins during the assembly of the head of the bacteriophage T4. Nature 227:680-685 
36. Langworthy TA, Pond JL (1986) Membranes and lipids of thermophiles. In: Brock TD (ed) Thermophiles: general, molecular, and applied microbiology. New York: Wiley-Interscience, pp 107-135

37. Liao H, McKenzie T, Hageman R (1986) Isolation of a thermostable enzyme variant by cloning and selection in a thermophile. Proc Natl Acad Sci (USA) 83:576-580

38. Lindsay JA (1988) Characterization of bacterial spores from high-temperature growth transformants of Bacillus subtilis. Curr Microbiol 16:265-269

39. Lindsay JA, Creaser EH (1975) Enzyme thermostability is a transformable property between Bacillus species. Nature 255:650-652

40. Lindsay JA, Creaser EH (1976) The biochemical and genetical basis of thermophily. In: Zuber $\mathrm{H}$ (ed) Enzymes and proteins from thermophilic microorganisms. Basel: Birkhauser-Verlag, pp 391-400

41. Lindsay JA, Creaser EH (1977) Purification and properties of histidinol dehydrogenases from psychrophilic, mesophilic and thermophilic bacilli. Biochem J 165:247-253

42. Lineweaver H, Burk D (1934) The determination of enzyme dissociation constants. J Amer Chem Soc 56:658-666

43. Ljungdahl LG (1979) Physiology of thermophilic bacteria. In: Zuber H (ed) Advances in microbial physiology. New York: Academic Press, 17:149-243

44. Ljungdahl LG, Sherod D (1976) Proteins from thermophilic microorganisms. In: Heinrich MR (ed) Extreme environments: mechanisms of microbial adaptation. New York: Academic Press, pp 147-187 
45. Lowry TC, Rosebrough NJ, Farr AL, Randall RJ (1951) Protein measurement with the Folin phenol reagent. J Biol Chem 193:265-275

46. Luria SE, Delbruck M (1943) Mutations of bacteria from virus sensitivity to virus resistance. Genetics 28:491-511

47. McDonald WC (1969) Linkage of a temperature-sensitive locus to the streptomycin region and its use in recombination studies with streptomycin mutants of Bacillus subtilis. Can J Microbiol 15:1287-1291

48. McDonald WC, Matney TS (1969) Genetic transfer of the ability to grow at $55 \mathrm{C}$ in Bacillus sutbilis. J Bacteriol 85:218-220

49. McElhaney RN (1976) The biological significance of alterations in the fatty acid composition of microbial membrane lipids in response to changes in environmental temperature. In: Heinrich MR (ed) Extreme environments: mechanisms of microbial adaptation. New York: Academic Press, pp 255281

50. Mozhaev VV, Martinek K (1984) Structure-stability relationships in proteins: new approaches to stabilizing enzymes. Enzyme Microb Technol 6:50-59

51. Nakamura N, Sashihara N, Nagayama, H, Horikoshi K (1989) Chracterization of pullulanase and $\alpha$-amylase activities of a Thermus sp. AMD33. Starch/Starke 41:112-117

52. Ng TK, Kenealy WR (1986) Industrial applications of thermostable enzymes. In: Brock TD (ed) Thermophiles: general, molecular, and applied microbiology. New York: Wiley-Interscience, pp 197-215

53. Oguma T, Kikuchi M, Mizusawa K (1990) Purification and some properties of cyclodextrin-hydrolyzing enzyme from Bacillus sphaericus. Biochim Biophys Acta 1036:1-5 
54. Ohta Y (1967) Thermostable protease from thermophilic bacteria. J Biol Chem. 242:509-515

55. Okada S, Kitahata S, Higashihara M, Fukumoto J (1969) Classification of $\alpha$-amylases by the action patterns on maltooligosaccharides. Agr Biol Chem 33:900-906

56. Oshima $\mathrm{T}$ (1975) Thermine: a new polyamine from an extreme thermophile. Biochem Biophys Res Com 63:1093-1098

57. Oshima $T$ (1979) Molecular basis for unusual thermostabilities of cell constituents from an extreme thermophile, Thermus thermophilus. In: Shilo $M$ (ed) Strategies of microbial life in extreme environments. Weinheim, New York: Verlag Chemie, pp 455-469

58. Oshima $\mathrm{T}$ (1982) Molecular mechanisms of bacterial adaptation to high temperatures. In: Kimura M (ed) Molecular evolution, protein polymorphism and the neutral theory. Tokyo: Japan Scientific Societies Press, pp 349-356

59. Oshima $\mathrm{T}$ (1986) The genes and genetic apparatus of extreme thermophiles. In: Brock TD (ed) Thermophiles: general, molecular, and applied microbiology. New York: Wiley-Interscience, pp 137-157

60. Pantoliano MW, Ladner RC, Bryan PN, Rollence ML, Wood JF, Poulos TL (1987) Protein engineering of subtilisin BPN': Enhanced stabilization through the introduction of two cysteines to form a disulfide bond. Biochem 26:20772082

61. Pazur JH, Okada S (1966) A novel method for the action patterns and the differentiation of $\alpha$-1,4-glucan hydrolases. $J$ Biol Chem 241:4146-4151

62. Perutz MF (1979) Molecular adaptation in haemoglobin and thermophilic bacteria. Differentiation 13:47-50 
63. Perutz MF, Raidt H (1975) Stereochemical basis of heat stability in bacterial ferredoxins and haemoglobin A2. Nature (London) 255:256-259

64. Piggot PJ, Hoch JA (1985) Revised genetic linkage map of Bacillus subtilis. Microbiol Rev 49:158-179

65. Pitcher WH (1986) Genetic modification of enzymes used in food processing. Food Technol 40(10):62-69

66. Priest FG (1989) Products and applications. In: Harwood CR (ed) Bacillus. New York: Plenum Press, pp 293-320

67. Reizer J, Grossowicz N, Barenholz Y (1985) The effect of growth temperature on the thermotropic behavior of the membranes of a thermophilic Bacillus. Composition-structure-function relationships. Biochim Biophys Acta 815:268-280

68. Rinderknecht H, Wilding P, Haverback BJ (1967) A new method for the determination of $\alpha$-amylase. Experientia 23:805

69. Rollence ML, Filpula D, Pantoliano MW, Bryan PN (1988) Engineering thermostability in subtilisin BPN' by in vitro mutagenesis. Critical Rev Biotech 8:217-224

70. Russell NJ (1984) Mechanisms of thermal adaptation in bacteria: blueprints for survival. TIBS March:108-112

71. Saha BC, Mathupala,SP, Zeikus JG (1988) Purification and characterization of a highly thermostable novel pullulanase from Clostridium thermohydrosulfuricum. Biochem J 252:343-348

72. Saha BC, Zeikus JG (1989) Novel highly thermostable pullulanase from thermophiles. Tibtech 7:234-239 
73. Saha BC, Zeikus JG (1990) Characterization of thermostable cyclodextrinase from Clostridium thermohydrosulfuricum 39E. Appl Environ Microbiol $56: 2941-2943$

74. Sakamoto N, Kotre AM, Savageau MA (1975) Glutamate dehydrogenase from Escherichia coli: purification and properties. J Bacteriol 124:775-783

75. Sambrook J, Fritsch EF, Maniatis T (1989) Molecular Cloning: A laboratory manual. Second edition, Cold Spring Harbour, New York: Cold Spring Harbour Laboratory Press

76. Sarvas M (1986) Protein secretion in bacilli. Curr Top Microbiol Immunol 125:103-125

77. Saunders GF, Campbell LL (1966) Ribonucleic acid and ribosomes of Bacillus stearothermophilus. J Bacteriol 91:332-339

78. Schagger H, Von Jagow G (1987) Tricine-sodium dodecyl sulfatepolyacrylamide gel electrophoresis for the separation of proteins in the range from 1-100 kDa. Anal Biochem 166:368-379

79. Sharp RJ, Bown KJ, Atkinson A (1980) Phenotypic and genotypic characterization of some thermophilic species of Bacillus. J Gen Microbiol $117: 201-210$

80. Shibaoka T, Inatani T, Hiromi K, Watanabe $T$ (1975) Substrate concentration dependence of the rate of maltose hydrolysis by saccharifying $\alpha$-amylase from B. subtilis. J Biochem 77:965-968

81. Shimizu M, Kanno M, Tamura M, Suekane M (1978) Purification and some properties of a novel $\alpha$-amylase produced by a strain of Thermoactinomyces vulgaris. Agric Biol Chem 42:1681-1688 
82. Singleton R, Amelunxen RE (1973) Proteins from thermophilic microorganisms. Bacteriol Rev 37:320-342

83. Sonnleitner B (1984) Biotechnology of thermophilic bacteria - growth, products, and application. 3rd Eur Cong Biotech, Munchen: Verlag Chemie, pp 70-138

84. Sonnleitner B, Grueninger H, Laforce R, Baier U, Fiechter A (1984) Production and application of thermophilic biocatalysts. Swiss Fed Inst Technol Pub I, Zurich, pp 29-37

85. Stahl S, Olsson O (1977) Temperature range variants of Bacillus megaterium. Arch Microbiol 113:221-229

86. Stellwagon E (1984) Strategies for increasing the stability of enzymes. In: Laskin AI, Tsao GT, Wingard LB (eds) Annals NY Academy of Sciences, Vol 434. Enzyme engineering 7. New York: NY Academy of Sciences, pp $1-6$

87. Stenesh J (1976) Information transfer in thermophilic bacteria. In: Heinrich MR (ed) Extreme environments. Mechanisms of microbial adaptation. New York: Academic Press, pp 85-101

88. Stetter KO, (1986) Diversity of extremely thermophilic archaebacteria. In: Brock TD (ed) Thermophiles: general, molecular, and applied microbiology. New York: Wiley-Interscience, pp 39-74

89. Suetsugu N, Koyama S, Takeo K, Kuge, T (1974) Kinetic studies on the hydrolyses of $\alpha-\beta$-, and $\gamma$-cyclodextrins by Taka-amylase A. J Biochem 76: $57-63$

90. Sundaram TK (1986) Physiology and growth of thermophilic bacteria. In: Brock TD (ed) Thermophiles: general, molecular, and applied microbiology. New York: Wiley-Interscience, pp 75-106 
91. Suzuki Y, Aoki R, Hayashi H (1982) Assignment of a p-nitrophenyl- $\alpha$-Dglucopyranoside-hydrolyzing $\alpha$-glucosidase of Bacillus cereus ATCC 7064 to an exo-oligo-1,6-glucosidase. Biochim Biophys Acta 704:476-483

92. Suzuki Y, Imai T. (1985) Bacillus stearothermophilus KP 1064 pullulan hydrolase. Its assignment to a unique type of maltogenic $\alpha$-amylase but to neither pullulanase nor isopullulanase. Appl Microbiol Biotechnol 21:20-26

93. Suzuki Y, Kishigami T, Abe S (1976) Production of extracellular $\alpha$ glucosidase by a thermophilic Bacillus species. Appl Environ Microbiol $31: 807-812$

94. Suzuki Y, Nagayama T, Nakano H, Oishi K (1987) Purification and characterization of a maltotriogenic $\alpha$-amylase I and a maltogenic $\alpha$-amylase II capable of cleaving $\alpha$-1,6-bonds in amylopectin. Starch/Starke 39:211-214

95. Suzuki Y, Oishi K, Nakano H, Nagayama T (1987) A strong correlation between the increase in number of proline residues and the rise in thermostability of five Bacillus oligo-1,6-glucosidases. Appl Microbiol Biotechnol 26:546-551

96. Suzuki Y, Tomura Y (1986) Purification and characterization of Bacillus coagulans oligo-1,6-glucosidase. Eur J Biochem 158:77-83

97. Ulmer K (1984) Protein engineering. In: Abelson PH (ed) Biotechnology and biological frontiers. Washington, DC: The American Association for the Advancement of Science, pp 110-120

98. Van Den Burg B, Enequist HG, Van Der Haar M, Eijsink VGH, Stulp BK, Venema G (1991) A highly thermostable neutral protease from Bacillus caldolyticus: Cloning and expression of the gene in Bacillus subtilis and characterization of the gene product. J Bacteriol 173:4107-4115 
99. Wasserman BP (1984) Thermostable enzyme production. Food Technol 38(2):78-98

100. Wasserman BP (1990) Evolution of enzyme technology: Progress and prospects. Food Technol 44(4):118-122

101. Watanabe K, Kuchino Y, Yamaizumi Z, Kato M, Oshima T, Nishimura S (1979) Nucleotide sequence of formylmethionine tRNA from an extreme thermophile, Thermus thermophilus HBS. J Biochem 86:893-905

102. Watanabe K, Oshima T, Saneyoshi M, Nishimura S (1974) Replacement of ribothymidine by 5-methyl-2-thiouridine in sequence GTC in tRNA of an extreme thermophile. FEBS Lett 43:59-63

103. Watanabe K, Seno T, Nishimura S, Oshima T, Imahori K (1973) The study of circular dichroic difference spectra applied to polynucleotides and ribonucleic acids. Polymer J 4:539-552

104. Welker NE (1976) Microbial endurance and resistance to heat stress. 20th Symp Soc Gen Microbiol. Cambridge University Press, pp 241-278

105. Welker NE (1976) Effect of temperature on membrane proteins. In: Heinrich M (ed) Extreme environments. Mechanisms of microbial adaptation. New York: Academic Press, pp 229-254

106. Wells JA, Estell DA (1988) Subtilisin - an enzyme designed to be engineered. TIBS 13:291-297

107. Wells JA, Vasser M, Powers DB (1985) Cassette mutagenesis: an efficient method for generation of multiple mutations at defined sites. Gene 34:315323 
108. Wolf J (1980) Bacillus thermophiles: a taxonomic assessment. Spore Newsletter 7:27-29

109. Yamagata H, Suzuki Y, Udaka S (1990) Amino acid residues determining the thermostability of bacterial $\alpha$-amylases. Protein Eng 3:352-353

110. Yoshida A, Iwasaki Y, Akiba T, Horikoshi K (1991) Purification and properties of cyclomaltodextrinase from alkalophilic Bacillus sp. J Fermen Bioeng 71:226-229

111. Yutani K (1976) Role of calcium ion in the thermostability of $\alpha$-amylase produced from Bacillus stearothermophilus. In: Zuber H (ed) Enzymes and proteins from thermophilic microorganisms: structure and function. Proceedings of the International Symposium, Zurich, July 28 to August 1, 1975. Basel: Birkhauser Verlag, pp 91-103

112. Yuuki T, Nomura $T$, Tezuka $H$, Tsuboi A, Yamagata $H$, Tsukagoshi $N$, Udaka S (1985) Complete nucleotide sequence of a gene coding for heatand $\mathrm{pH}$-stable $\alpha$-amylase of Bacillus licheniformis: comparison of the amino acid sequences of three bacterial liquefying $\alpha$-amylases deduced from the DNA sequences. J Biochem 98:1147-1156

113. Zeikus, JG, Taylor MW, Brock TD (1970) Thermal stability of ribosomes and RNA from Thermus aquaticus. Biochim Biophys Acta 204:512-520

114. Zuber H (1979) Structure and function of enzymes from thermophilic microorganisms. In: Shilo $M$ (ed) Strategies of microbial life in extreme environments. Dahlem Konferenzen. Berlin, pp 393-415

115. Zuber H (1981) Structure and function of thermophilic enzymes. In: Eggerer $\mathrm{H}$, Huber R (eds) Structural and functional aspects of enzyme catalysis: 32nd Colloquium der Gesellschaft fur Biologische Chemie. Berlin, Heidelberg, New York: Springer-Verlag, pp 114-127 
116. Zuber H (1981) Thermophily. Basic Life Science 18:499-512

117. Zuber H (1988) Temperature adaptation of lactate dehydrogenase: structural, functional and genetic aspects. Biophys Chem 29:171-179

118. Zulli F, Schneiter R, Urfer R, Zuber H (1991) Structure and function of Llactate dehydrogenases from thermophilic and mesophilic bacteria, XI. Engineering thermostability and activity of lactate dehydrogenases from Bacilli. Biol Chem Hoppe-Seyler 372: 363-372 


\section{BIOGRAPHICAL SKETCH}

Bradley Martin Krohn was born May 16, 1959, in Springfield, VT. After graduating from Springfield High School in 1977, he attended Williams College, Williamstown, MA, and received his B.A. in biochemistry in 1981. He then moved to Sarasota, FL, where he pursued a career in restaurant management for four years. He realized a scientific career was in his better interests, so in 1985 he enrolled in the Food Science and Human Nutrition Department at the University of Florida. After one year postbaccalaureate, he was accepted into the graduate program. Upon graduation in December, 1991, he will work as a postdoctoral associate in the New Products group of the Monsanto Company, St. Louis, MO. He plans to pursue a career in applied molecular biology and microbiology. 
I certify that I have read this study and that in my opinion it conforms to acceptable standards of a scholarly presentation and is fully adequate, in scope and quality, as a dissertation for the degree of Doctor of Philosophy.

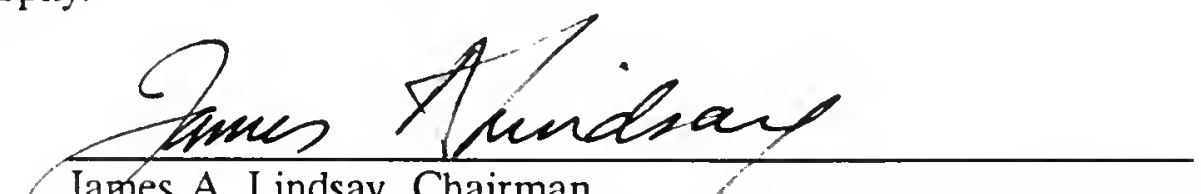

James A. Lindsay, Chairman

Associate Professor of Food Science and Human Nutrition

I certify that I have read this study and that in my opinion it conforms to acceptable standards of a scholarly presentation and is fully adequate, in scope and quality, as a dissertation for the degree of Doctor of Philosophy.

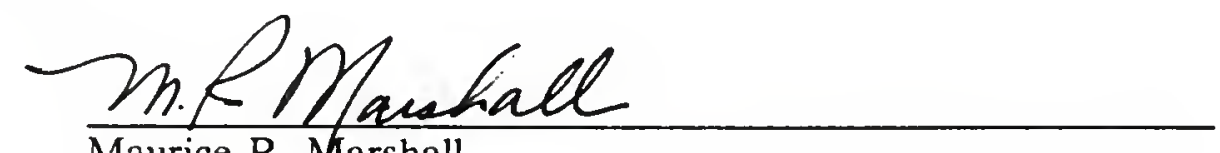

Maurice R. Marshall

Professor of Food Science and Human Nutrition

I certify that I have read this study and that in my opinion it conforms to acceptable standards of a scholarly presentation and is fully adequate, in scope and quality, as a dissertation for the degree of Doctor of Philosophy.

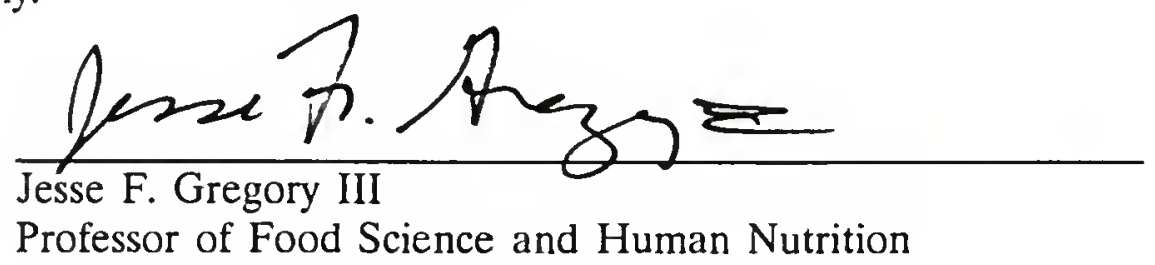

I certify that I have read this study and that in my opinion it conforms to acceptable standards of a scholarly presentation and is fully adequate, in scope and quality, as a dissertation for the degree of Doctor of Philosophy.

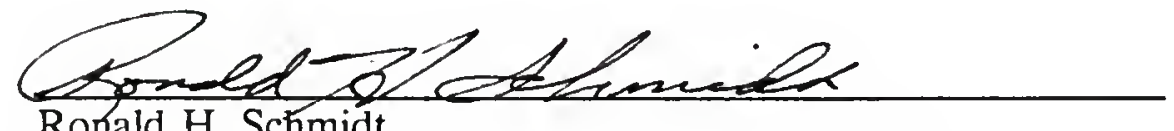

Ronald H. Schmidt

Professor of Food Science and Human Nutrition 
I certify that I have read this study and that in my opinion it conforms to acceptable standards of a scholarly presentation and is fully adequate, in scope and quality, as a dissertation for the degree of Doctor of Philosophy.

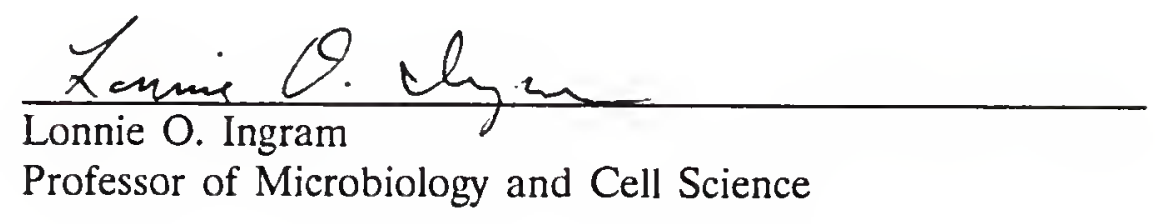

I certify that I have read this study and that in my opinion it conforms to acceptable standards of a scholarly presentation and is fully adequate, in scope and quality, as a dissertation for the degree of Doctor of Philosophy.

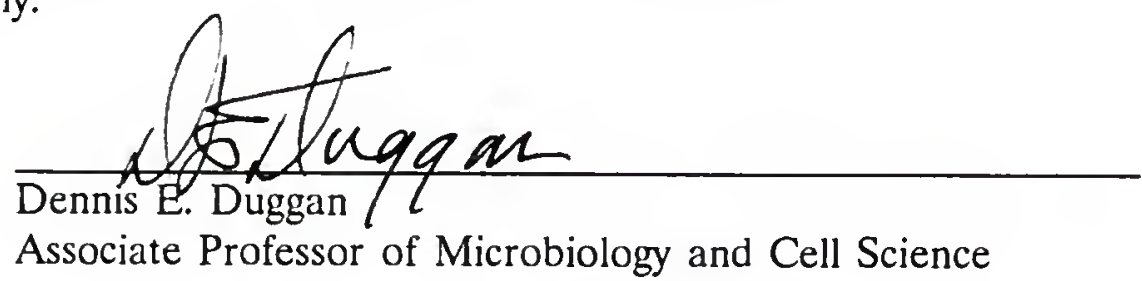

This dissertation was submitted to the Graduate Faculty of the College of Agriculture and to the Graduate School and was accepted as partial fulfillment of the requirements for the degree of Doctor of Philosophy.

December 1991

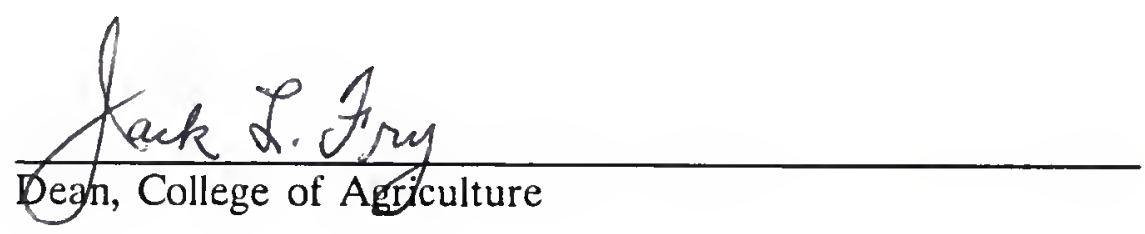

Dean, Graduate School 


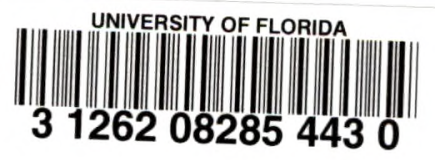

